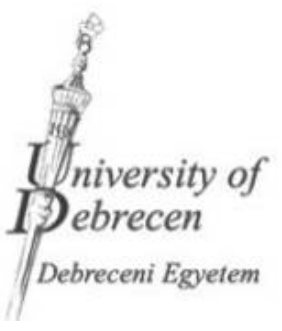

\title{
KÜLÖNLEGES BÁNÁSMÓD
}

INTERDISZCIPPLINÁRIS

(OPEN ACCES - NYÍLT HOZZÁFÉRÉSÜ)

SZAKMAI LAP

ISSN 2498-5368

Web:

http://old.gyfk.unideb.hu/kulonlegesbanasmod/

III. évf., 2017/1. szám

DOI 10.18458/KB.2017.1.1 


\title{
IMPRESSZUM
}

\section{KÜLÖNLEGES BÁNÁSMÓD - INTERDISZCIPLINÁRIS SZAKMAI LAP}

\begin{abstract}
Alapítva: 2014-ben.
A Nemzeti Média- és Hírközlési Hatóság Hivatala a médiaszolgáltatásokról és a tömegkommunikációról szóló 2010. évi CLXXXV. törvény 46.§ (4) bekezdése alapján nyilvántartásba vett sajtótermék (határozatról szóló értesítés iktatószáma: CE/32515-4/2014).
\end{abstract}

Kiadó: Debreceni Egyetem

A kiadó székhelye:

Debreceni Egyetem

4032 Debrecen, Egyetem tér 1.

Kiadásért felelős személy:

Szilvássy Zoltán József, rector (Debreceni Egyetem)

\author{
A szerkesztőség levelezési címe: \\ Debreceni Egyetem \\ Gyermeknevelési és Felnőttképzési Kar \\ Különleges Bánásmód folyóirat szerkesztősége \\ 4220 Hajdúböszörmény, Désány István u. 1-9. \\ Tel/fax: 06-52/229-559 \\ E-mail: titkarsag@ped.unideb.hu \\ Web: www.degyfk.hu \\ Szerkesztésért felelös személy: \\ Mező Ferenc (Eszterházy Károly Egyetem) \\ Tördelőszerkesztő: Mező Ferenc, Roskó Tibor
}

\section{Alapító főszerkesztő: Mező Ferenc}

Tanácsadó testület ( $\mathrm{ABC}$ rendben):

Balogh László (Magyar Tehetséggondozó Társaság, Magyarország)

Gerevich József (Eötvös Lóránd Tudományegyetem, Magyarország)

Hatos Gyula ( Magyarország)

Koncz István (Professzorok az Európai Magyarországért Egyesület, Magyarország)

Mesterházy Zsuzsanna (Eötvös Lóránd Tudományegyetem, Magyarország)

Nagy Dénes (Melbourne University, Ausztrália)

Varga Imre (Szegedi Tudományegyetem, Magyarország)

\section{Szerkesztőség (ABC rendben):}

Bernáth Krisztina (Partiumi Keresztény Egyetem, Románia)

Dávid Mária (Eszterházy Károly Főiskola,

Magyarország)

Egri Tímea (Eötvös Lóránd Tudományegyetem, Magyarország)

Fónai Mihály (Debreceni Egyetem, Magyarország)

Horváth László (Debreceni Egyetem, Magyarország)

H. Tóth István (Károly Egyetem, Csehország)

János Réka (Babes-Bolyai Tudományegyetem, Románia)

Lepeš, Josip (University of Novi Sad, Szerbia)

Kelemen Lajos (Poliforma Kft., Magyarország)

Kiss Szidónia (Babes-Bolyai Tudományegyetem,

Románia)

Kondé Zoltánné Dr. Inántsy-Pap Judit (Debreceni

Egyetem, Magyarország)

Kormos Dénes (Miskolci Egyetem, Magyarország)

Láda Tünde (Debreceni Egyetem, Magyarország)
Márton Sándor (Debreceni Egyetem, Magyarország) Mező Katalin (Debreceni Egyetem, Magyarország) Molnár Balázs (Debreceni Egyetem, Magyarország) Nagy Lehocky Zsuzsa (Konstantin Filozófus Egyetem Nyitra, Szlovákia)

Nemes Magdolna (Debreceni Egyetem, Magyarország)

Roskó Tibor (Debreceni Egyetem, Magyarország)

Sarka Ferenc (Miskolci Egyetem, Magyarország)

Schéder Veronika (Debreceni Egyetem, Magyarország)

Szabó Edina (Debreceni Egyetem, Magyarország)

Szilágyi Barna (Debreceni Egyetem, Magyarország)

Vargáné Nagy Anikó (Debreceni Egyetem,

Magyarország)

Vass Vilmos (Budapesti Metropolitan Egyetem,

Magyarország)

Váradi Natália (II. Rákóczi Ferenc Kárpátaljai magyar

Főiskola, Ukrajna)

Note: The title of the journal comes from a Hungarian Act CXC of 2011. on National Public Education in which they use the term 'Különleges Bánásmód', and this translates as Special Treatment, but this encompasses the areas of Special Educational Needs, Talented Children and Children with Behaviour and Learning Difficulties. The adoption of Special Treatment is therefore in accordance with Hungarian law, but it is recognised that the translation may not be perfect in expressing the full meaning of what is encapsulated in this term. 


\section{CONTENT}

THEORETICAL AND EMPIRICAL STUDIES

Anita Kathyné Mogyoróssy and Erika Beáta Nagy:

Karolina Eszter Kovács and Beáta Erika Nagy:

Adolescents' health behaviour according to sport and family structure

Adrienn Oravecz and Csilla Noémi Borsodi:

Teachers in a disadvantaged position.

Emília Lívják:

The body: inside and outside.

METHODOLOGICAL STUDIES

Tamás Józsa and Beáta Erika Nagy:

Analyzing the factors influencing health behavior in childhood - the impact of media- and computer usage on health behavior

Judit Tanczos:

Monitoring and supporting the development of children and young people in the united kingdom.

Réka Tóth:

Improvement of fine motor skills in cerebral paretic patients.

Cristina Catalano:

Learning difficulties of children with emigrant parents

BOOK REVIEWS

Adrienn Oravecz:

Book review

Adrienn Oravecz:

Internationalising conductive education reports from recent advances in conductive education

Adrienn Oravecz:

Genesis.....

Adrienn Oravecz:

Intelligent love parents' action for conductive education 


\section{THEORETICAL AND EMPIRICAL} STUDIES 


\title{
FACTORS OF PARENTAL INVOLVEMENT IN RELATION TO CHILDREN'S BEHAVIORAL SYMPTOMS
}

\author{
Authors: \\ Anita Kathyné Mogyoróssy \\ Debreceni Református Hittudományi \\ Egyetem \\ Erika Beáta Nagy \\ University of Debrecen \\ E-mail address of the first author: \\ kathyne@gmail.com
}

Lectors:

\author{
Ildikó Pinczésné Palásthy \\ Debreceni Református Hittudományi \\ Egyetem \\ George Seel \\ University of Debrecen \\ Ferenc Mező \\ Eszterházy Károly University \\ Edina Szabó \\ University of Debrecen
}

Kathyné Mogyoróssy, Anita and Nagy, Erika Beáta (2017): Factors of parental involvement in relation to children's behavioral symptoms. Különleges Bánásmód, III. évf. 2017/1. szám, 7-25. DOI 10.18458/KB.2017.1.7

\begin{abstract}
In our study the features of contact between parents and teachers and the particular patterns they take were examined in connection with children's behavioural symptoms. With cluster analysis, seven clearly analysable patterns of contact were identified, the two most frequent of which (unifacial and formal) do not favour problem solving, nor provide parental satisfaction.

Two patterns (flexible and adaptive) proved to be the most satisfying and the most effective. Children's symptoms (social problems, anxiety, somatization, attention deficit, deviant behaviour, agressivity) are significantly related to the quality of parent-teacher contact. In the case of the less favourable and less effective contact forms, parents report more behavioural symptoms, while in the case of the flexible, adaptive, emotionally satisfying and effective problem solving contact forms, there are fewer symptoms. These results draw attention to important tasks on many levels: to work out operable patterns of parent-teacher contact, to better understand the role and tasks of teacher training, and the need to involve experts to assist in developing parent-teacher contact, which is also indispensable in terms of helping and developing children and their mental health.
\end{abstract}

Keywords: Parental involvement, Parent-pedagogue contact, Children's behavioural symptoms, Teacher training

Disciplines: Psychology, Pedagogy

\footnotetext{
${ }^{1}$ The editorial board does not take any responsibilty for the English of the papers. Indeed, we made some slight changes but wanted to keep the style of the authors.
} 


\section{Absztrakt}

Tanulmányunkban a szülők és a pedagógusok kapcsolattatásának jellegzetességeit, mintázatait tártuk fel a gyermekek viselkedéses tüneteivel összefüggésben. Klaszteranalízis segítségével hét jól értelmezhető kapcsolattartási mintázatot sikerült azonosítani, melyek közül a leggyakoribb kettő (egysíkú és formális) nem kedvez a problémamegoldásnak és a szülöi elégedettségnek. Két mintázat (rugalmas és adaptív) bizonyult a legkielégítőbbnek és leghatékonyabbnak. A gyermekek tünetei (társkapcsolati problémák, szorongás, szomatizáció, figyelmi problémák, deviáns viselkedés, agresszivitás) és a szülő-pedagógus kapcsolattartás minősége szignifikánsan összefügg. A legkevésbé kedvező és hatékony kapcsolattartási formák esetében több gyermeki tünetröl számolnak be a szülők, míg a rugalmas, adaptív, érzelmileg kielégítő és a problémamegoldásban sikeres kapcsolati formák esetében kevesebb tünet jelentkezik. Ezek az eredmények fontos feladatokra hívják fel a figyelmet több síkon is: a szülő-pedagógus kapcsolattartás müködőképes formáinak kidolgozására, a pedagógusképzés szerepére és feladataira, illetve a segítő szakemberek bevonásának szükségességére a szülöpedagógus kapcsolat fejlesztése céljából, ami a gyermekek segítése, fejlesztése, mentálhigiénéje szempontjából is elengedhetetlen.

Kulcsszavak: szülői bevonódás, szülö-pedagógus kapcsolattartás, gyermekviselkedési tünetek, pedagógusképzés

Diszciplína: Pszichológia, pedagógia

Parent-teacher cooperation is a necessary condition for the effective upbringing and education of children. As provided by the National Public Education Law (2011. CXC.) of Hungary and other documents, parents have the right to be involved in school life, something which is both their obligation and responsibility.

Social processes are manifest in the education system: the system recognises social, economic, and political changes and reacts to these phenomena. School can also be considered a reduced society. In the last few years global phenomena (multiculturalism, Americanization, the consumer society) have been recognisable features of school life (Torgyik, 2009).

There are great differences in regard to what parents consider a teacher's tasks. Some parents emphasize upbringing-related tasks and the role of the teacher's personality as a guide (Hunyadi, 2002), while others believe teachers' competence only extends to educational tasks (Lénárd, 2003).

When an educational problem occurs, both amateurs and experts have suggestions about how to solve it; however, these adult roles are different in many ways. The parental role carries with it a certain degree of prejudice, a high level of emotional intensity, and strong bonding; its extent is limitless, and its main dimension is care. The teacher's role, on the other hand, is objective, keeps optimal emotional distance, and is not responsible for all areas of life, but only education (Katona and Szitó, 2005).

Successful cooperation is more difficult because of the social and economic status of the family, the qualifications of the parents and their values. Consequently, their educational attitudes, conflict management strategies and communication styles are different; moreover, it often happens that these also differ from the school's own expectations. (When teachers evaluate children their values and personalities also filter into the cooperation relationship) (Szabó, 2006). 


\section{Typical forms of parent-teacher contact in Hungary}

Füle examined the most typical contact forms in 1983 and 1991 in Budapest, and proposed solutions to make them better, solutions which are still valid today (Füle, 2002).

Éva Szabó offered suggested solutions in her study of 2003. She pointed out that circumstances are also important: on which occasions, how often and in what atmosphere do teachers and parents meet each other. Hegedüs and Podráczky (2011) asked teachers and parents about forms of contact in focus group discussions.

According to Füle's results, parents often have different needs from what is discussed at parents' meetings. It would be preferable to carry out a prior needs assessment, and after this for parents and teachers to determine topics together (Füle, 2002).

Parents' meetings are usually organized in the classroom. Its layout creates a superiorsubordinate relationship and parents tend to re-live their own school memories, which reproduce old reactions, too (for example anxiety, defiance, subservience, passivity). Other layouts (chairs placed around the room, or in a U-shape) could be an alternative which would suggest equal contact and create the feeling that everybody's opinion is important.

Information is often impersonal and unilateral; there is no discussion, only statements. One solution would be to communicate information where no discussion is needed in other ways (letter, reminder, e-mail, up-to-date website, chat forums). This would make more time which could be used to organize discussions which are closer to topics that parents wish to talk about. These discussions could be informal conversations, or educational lectures (with guest lecturers) which finish with a discussion. Teachers could also present the methods they use, or review a book (Szabó, 2006). Regular participation in parents' meetings is harder, because the appointments are in working hours (Hegedüs and Podráczky, 2012).

In the case of consulting hours, it is necessary to emphasize the environment: cosy, separated rooms make for calm conversation. The topics for discussion at consulting hours are generally school requirements, methods, textbooks, further education opportunities, free time at school, other opportunities, the child's out of school activities, the school calendar and any problems arising. It is important to make a clear agreement in terms of what the teacher, the parent and the child need to do to solve the problem (Füle, 2002). The consulting hour's greatest enemy is the lack of time.

According to Júlia Szekszárdi's (2000) results, teacher-parent contact is mainly limited to dealing with problems.

In focus group discussions another, totally different, problem occurs: usually the parents who appear in consulting hours are caring parents who want to be informed about their child's positive progress and need their competence as parents to be confirmed (Hegedüs and Podráczky, 2012).

Éva Szabó divides the tasks carried out in consulting hours into pre-, during and postconsultation tasks. Prearranged appointments could be a part of the arrangement, so that any rush could be avoided. Making prior appointments and fixing their duration make contact more calculable, concentrated and efficient. It is useful to keep some perspective and use well-tried methods. It is worth making positive comments about the child and then inviting the parents to speak, to discover their view-point. Then the teacher can give his/her opinion about the child and continue with any proposed solutions and strategies. Finally, it is practical to close the conversation with encouragement and make a new appointment with the parents, when they can evaluate the results (Szabó, 2006).

In Füle's opinion open days are, above all, a way of satisfying curious parents: they can see what their child's everyday school life is like, and observe their relationships with classmates and teachers (Füle, 2002).

It is very important that parents observe real school life, and open days and chances for classroom observation should be more regular. In this way parents can get a real perspective 
on school work, try to understand the teacher's position and avoid the feeling that they are only seeing the 'shop window' (Szabó, 2006).

Márta Winkler (2003) also emphasizes that parents should be involved in school life through regular classroom observation with the aim of getting to know teachers and their educational principles, as well as the community the child is studying in. She stresses the importance of common experiences, and urges out of school contact between children and family. The educational effectiveness of a teacher is multiplied in a frank atmosphere when the child's real interests are represented by parents and teachers in mutual understanding.

In 1991 Füle (2002) reported regular home visits, but nowadays these are not obligatory in public education, and parents cannot be forced to let anyone (even teachers) into their home. In focus group examinations most teachers mentioned overwork and the lack of time (Hegedüs and Podráczky, 2012). In my experience teachers mainly propose family visits when they think this is the only possibility to meet the parents. The type of settlement may also influence whether or not parents take advantage of this opportunity. In smaller settlements, where people know each other, it could be more typical.

There are other possibilities beside personal contact. A message booklet can keep parents up-to-date with their child's performance, attitude and other important information, although it does not inform them about their child's behaviour and general well-being, unless the teacher feels it indicates a problem.

Different forms of electronic communication (telephone, e-mail, websites) are quite typical in families with higher social and economic status. Beside the discriminating effect of significant social differences, teachers mentioned that parents can misuse the opportunities offered by electronic communication.

According to focus group surveys, the other, alternative forms of contact (freetime hobbies, common events) are less preferred, because of the lack of time (Hegedüs and Podráczky, 2012).

Judit Lannert and Júlia Szekszárdi carried out an online investigation in 2013 into contact between parents and teachers. According to their results, more than half of parents do not use the majority of communication possibilities available. Contact between parents and teachers is not intensive; they meet more or less quarterly or termly. The most typical forms of communication are the parents' meeting and the message booklet. Although the consulting hour is not the most frequent, both parents and teachers think it is the most effective, mainly because of the opportunity it offers for personal contact. As we can see, the older the child, the less active the contact between parent and teacher. By the time the child goes to high school, this contact has become totally impersonal; in line with this, and, as a consequence of it, in the judgement of the parents there is a steady deterioration in the quality of the contact.

According to the authors this situation can be explained: most parents (and the majority of teachers) are not aware of the communication possibilities that exist. This field is not dealt with in teacher training - there is no direct training to be a form tutor. So most teachers use their own, characteristically traditional, deficient experiences, and so bad habits are continued from generation to generation.

Parents, however, want to receive support in educational topics, a point which is demonstrated by the existence of popular online forums (Lannert and Szekszárdi, 2015).

\section{RESEARCH}

The aim and hypotheses of this study

Aim: In our study the features of contact between parents and teachers and the special patterns of this contact were examined in relation to children's behavioural symptoms. 
Hypothesis 1: We supposed that frequent and flexible contact possibilities were considered more positive by parents if they help successful cooperation and solve any problems that have occurred.

Hypothesis 2: We supposed that when forms of parent-teacher contact are more appropriate, children have fewer behavioural problems.

Hypothesis 3: We supposed that the children of parents who have more positive contact with teachers have fewer behavioural problems.

\section{Participants in the study}

1464 subjects took part in our study, all of whom were parents of 6-12 year old children. $85 \%$ of the participants were women (mother), 15\% men (father). This difference can be explained by the fact that child rearing and keeping contact with the school are traditionally tasks carried out by mothers. This research was conducted from 2015 to 2016.

\section{Measures used:}

1. The CBCL (Child Behaviour Checklist) (Gádoros, 2007): the version for parents of 7-14 year old children. The Child Behaviour Checklist (CBCL) questionnaire was edited by Th. Achenbach et al. in the 1980s on the basis of symptom lists created to diagnose and measure the behavioural and emotional problems of children and adolescents. The original questionnaire contains 114 items, and 8 problem scales; the abridged version which was tested by Hungarian children, was called the Child Behaviour Checklist (Gyermekviselkedési Kérdöív), and is linked with the name of Júlia Gádoros. The abridged Hungarian version has three subvariants, depending on who the subject is. The teacher's version contains 47 questions, the parent's version contains 46 questions, and normative values refer to 4-14 year old children. The self-assessment version contains 44 questions and normative values refer to 10-14 year old children. All the three versions have 6 scales, each of which have a further 3 scales.

a. Problems with social connections scale: this scale indicates children's problems with their classmates and with their parents.

b. Anxiety, depression scale: summarizes emotional symptoms relating to anxiety and mood disorders.

c. Somatization scale: summarizes physical symptoms which have no known medical cause.

d. Attention deficit scale: mainly refers to problems with attention deficit and hyperactivity.

e. Deviant behaviour scale: summarizes indications relating to violations of required behavioural norms.

f. Agressivity scale: refers to a child's impetuosity, agressivity and aptitude for destruction

g. Internalization: a summarized scale created from the problems of social communication scale and the anxiety/depression scale. These symptoms occur in a child's emotional life and they present difficulties mainly for the child, who suffers from these symptoms, and not for the surrounding environment.

Externalization: a summarized scale created from the deviant behaviour scale and the agressivity scale. It includes behaviours which disturb the surrounding environment.

The total value of problems: the total value of the 6 scales. 
High scores for internalization may indicate an excess of control, while high scores for externalization may indicate undercontrolled behaviour (Bíró, 2010).

2. The types of contact between parents and teachers and the level of satisfaction with the contact were examined by metaphor analysis and with a short questionnaire. The meaning of the word metaphor is 'transmission'; when we link two concepts together by the similarity of their content. In the course of creating metaphors, the deeper, unconscious elements and experiences of our personality may emerge (Vámos, 2001). We used the metaphor analysis method by creating independent metaphors. Subjects were asked to describe the relationship between parents and teachers, by continuing the following sentence: The relationship between parents and teachers is like..., and to explain their answers.

The answers were analysed by content analysis. According to the metaphors produced, we created two derived variables during the data analysis and category creation:

- The emotional quality of the relationship between parents and teachers (negative or ambivalent, neutral, positive).

- The equality of the relationship between parents and teachers (equal, subordinatesuperior).

Other variables were based on the questions in the questionnaire:

- 'How do you consider your relationship with your child's teacher/form tutor?' (not good, acceptable, good, excellent)

- 'If any problem occurs how can you cooperate?' (insufficiently, quite well, very well)

- 'How often do you have contact?' (once a half-year or more rarely, quarterly, once a month, up to several times a week)

- 'Do you think the frequency of contact is sufficient?' (not sufficient, sufficient, totally sufficient)

- 'Do you think this form of contact is adequate?' (not adequate, adequate, totally adequate)

- How do you maintain contact with your child's teacher/form tutor? (parents' meetings, consulting hours, by appointment, by phone, family visit, other)

In the 'other' category there were several answers relating to the nature of the contact: informal, unintended, random (anytime, anywhere, whenever, in the morning before teaching, in the afternoon after teaching, on the street); all of these were grouped together and interpreted as 'informal'.

The contact by e-mail and by telephone categories were grouped together and were interpreted as 'telecommunication'.

Neither message booklet and nor electronic mark-book (these are special Hungarian methods used to communicate with parents) were represented in the sample to a significant degree (under 1\%).

Data were analysed with the help of SPSS version 13.0 software. Cluster analysis, Pearson's chi-squared test, the Kruskal-Wallis test, the Jonckheere-Terpstra test and the Mann-Whitney test were all used.

\section{RESULTS}

Answers relating to the contact between parents and pedagogues were distributed as follows: 
Emotional quality and the equality of the relationship between parents and teachers

When examining data by metaphor analysis, $66.2 \%$ of the sample created metaphors. $10.1 \%$ of these subjects considered the emotional quality of the relationship between parents and teachers to be negative or ambivalent, $50.2 \%$ considered it to be neutral and $39.7 \%$ positive.

As regards equality, $89.3 \%$ of the respondents considered the relationship between parents and teachers to be equal, and $9.6 \%$ subservient, while in $5.1 \%$ of cases the metaphor did not refer to the relationship. These latter variables were not taken into consideration when making comparisons with other variables.

\section{How do parents view the relationship?}

$42.6 \%$ of the subjects considered the relationship to be excellent, $40.4 \%$ good, $14.3 \%$ acceptable, while $1.9 \%$ of the respondents thought it was not good. (These results correspond with Füle's poll results (1983) in which $84 \%$ of parents were pleased with the quality of education to a certain extent). This is a very positive result, when compared with the emotional quality of the relationship (which resulted in less positive results), so we can see that in the case of metaphor analysis the subjects had less intention of creating the kind of answers which were expected. When the process of responding is not limited to exclusively conscious factors we can acquire a much more subtle picture.

'Cooperation when a problem occurs' was judged quite positively by respondents (but not excessively so): $51.9 \%$ of them considered the level of cooperation to be very good, $39.9 \%$ quite good, and $7.9 \%$ insufficient.

\section{Satisfaction with the frequency of meetings}

More than half of the subjects contact their child's teacher/form tutor once a month, or more rarely (there was no real difference in frequency between primary school and middle school). $55.1 \%$ respondents reported this frequency as totally sufficient, according to $38.7 \%$ it was quite sufficient, while $5.5 \%$ considered it insufficient.

The Pearson's chi-squared test revealed that these two outcome variables have a significant relationship. The more frequent the contact between parents and teachers, the more satisfied the parents are.

Further correlations are observable between certain variables.

The Kruskal-Wallis test revealed a significant relationship between all other dichotomous variables $(p<0.01)$, except for equality. The Jonckheere-Terpstra test (which measures monotony) also revealed significant results (at least $\mathrm{p}<0.05$ ).

Those parents who had a positive view of the nature and the emotional quality of the relationship between parents and teachers tend to have more frequent contact and are more satisfied with the frequency and the type of contact, and they feel cooperation is more successful when a problem occurs (see Figure 1) than those parents who considered the relationship sufficient or quite good, or who had a no more than neutral view of the emotional quality of the relationship. 
Figure 1-Relationship between cooperation when a problem occurs and quality of contact

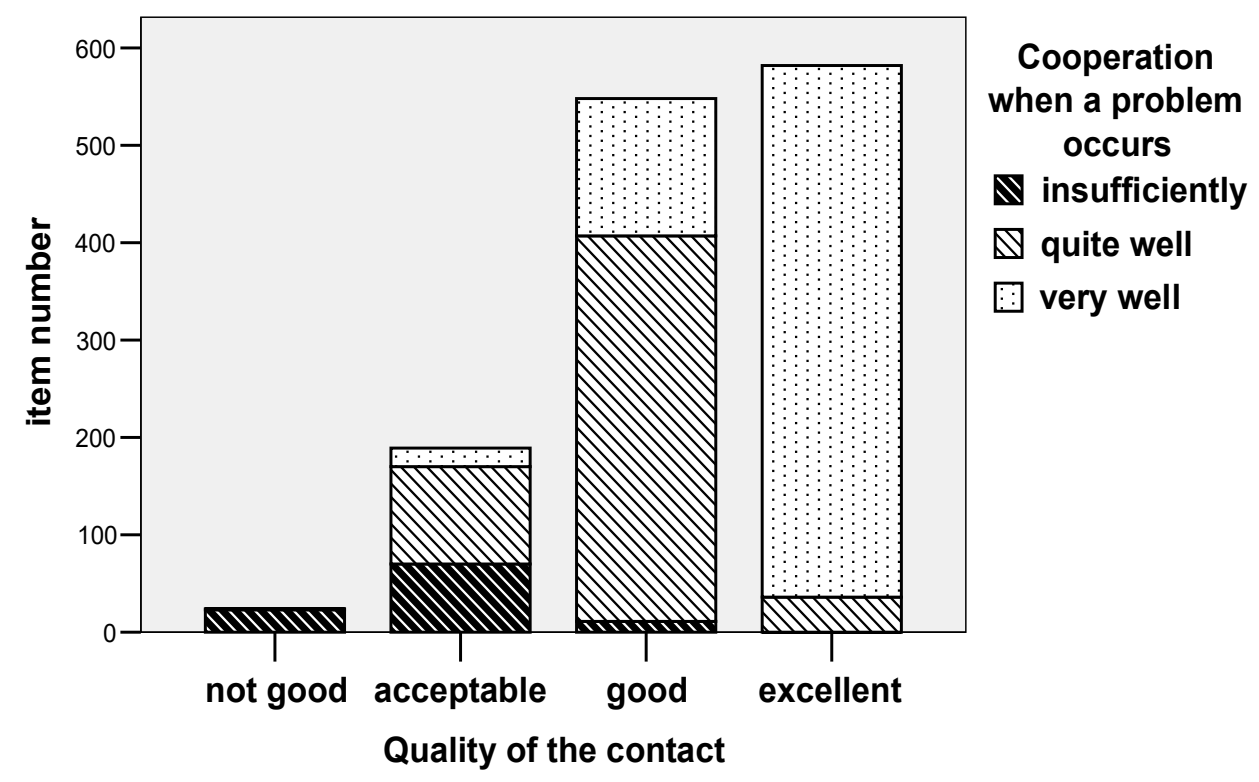

As regards the question of frequency, there is a positive correlation between more frequent contact and the other variables. Those parents who meet more frequently with their child's teacher are more satisfied with the frequency and the type of the contact, as well as with the relationship between parents and teachers and with problem solving (see Figure 2). Satisfaction with frequency revealed the same clear correlations.

\section{Figure 2 - Relations between cooperation when a problem occurs and frequency of contact}

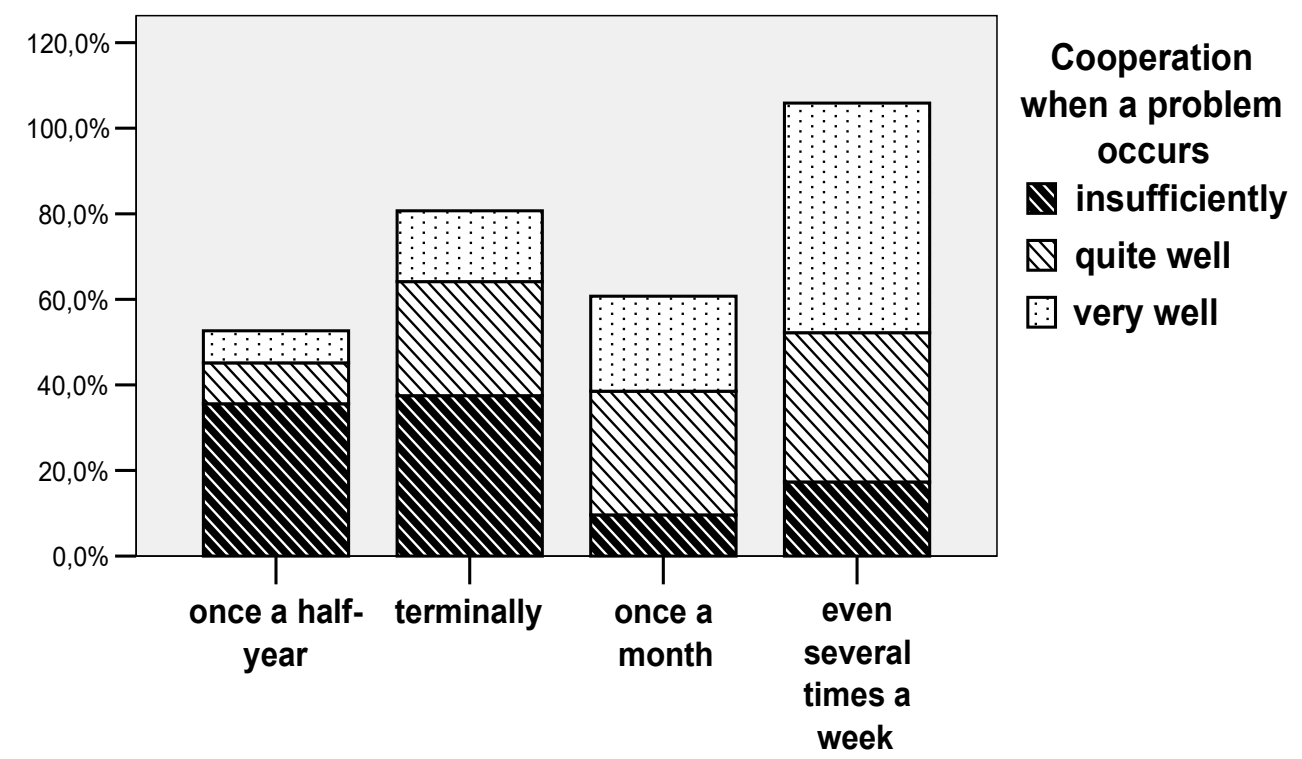

Frequency of the contact

These results draw attention to the fact that parents and teachers need to be motivated to meet frequently.

There is a strong significant correlation between cooperation when a problem occurs (as we have already observed) and the other variables: the more frequent the contact, and the more satisfied the parents are with it, and the more positive they consider the relationship, the more 
they can cooperate if any problem occurs. When they are less satisfied, the relationship is more negative and less frequent, which has a negative effect on cooperation, too.

The question of equality divides the sample of parents who answered the metaphor question into two subgroups: those who feel the relationship is an equal one, and those who feel it is a relationship between subordinate and superior. The Mann-Whitney test revealed a significant difference between the two subgroups as regards emotional quality: an equal relationship means a more positive emotional relationship at the same time.

Examining the typical forms of relationships we found that parents tend to use the conventional and organized forms of contact offered by the school: parents' meetings and consulting hours (which rarely conform to parents' needs). These are complemented with more flexible types of contacts, such as telecommunication, and informal meetings. As we can see, the home visit has fallen out of favour, due to the fact that, on the one hand that is not obligatory for teachers, while on the other hand parents are not obliged to let anyone into their home if they do not want to (see Table 1).

Table 1 - percentage breakdown of forms of contact

\begin{tabular}{|l|l|}
\hline Forms of contact & Percentage of parents \\
\hline parents' meetings & $87.2 \%$ \\
\hline consulting hours & $35.4 \%$ \\
\hline telecommunication & $31.4 \%$ \\
\hline informal meetings & $14.4 \%$ \\
\hline previously agreed meetings & $10.9 \%$ \\
\hline home visits & $2.0 \%$ \\
\hline
\end{tabular}

To the question 'Do you think this form of contact is adequate?' $61.8 \%$ of the parents answere that it is totally adequate, $32.6 \%$ found it adequate and only $4.7 \%$ said that it is not adequate. In in most primary schools in the Hungarian public education system, there is a parents' meeting 3-4 times a year.

Figure 3 - The patterns of contact

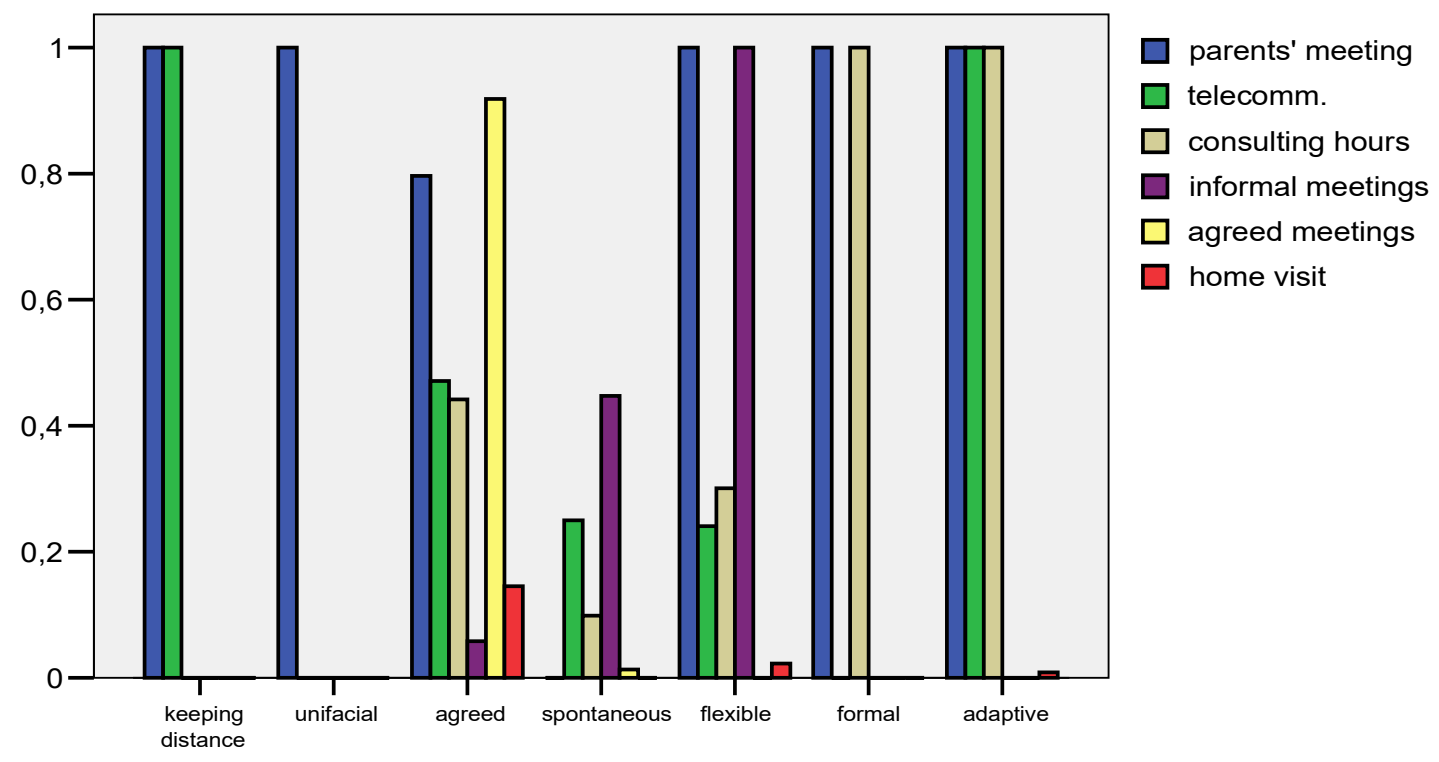


Considering the children's age (6-12 years) and the requirements of effective problem solving, in many cases the contact is infrequent and characterized by conventional, rigid forms. We think that the reason for this is firstly habit (parents' own school socialization), and secondly the lack of other alternatives. According to demographic parameters, the younger age-group prefer flexible types of contact, which have been introduced as a result of the increasing openness of schools after the political changes of 1989-90.

These data were examined with cluster analysis; seven clusters were identified, which indicate clearly analysable patterns of contact (see Figure 3).

We tried to give these clusters clear, precise names, which express the essentials of certain patterns of contact (see Table 2). We started with the characteristics of certain types of relationships: the parents' meeting is not so personal, because the subject is the class not the child, but it may create the opportunity for parents to get to know each other and declare their intention of cooperating with the school. The consulting hour is personal, but the disadvantage is that the parent or teacher cannot react immediately when they want to negotiate something. An informal meeting is personal and flexible, but there is less time to talk because there is no fixed appointment. Telecommunication is fast; if any problem occurs, we can talk immediately, but there is no personal presence, non-verbal communication is deemphasized and the time is limited. So we can see that, on its own, each type of contact is incomplete.

The patterns of contacts and their labels and their percentages are presented in the chart below.

Table 2 - Percentage breakdown of the patterns of contact

\begin{tabular}{|l|l|r|r|}
\hline The patterns of contact & Name & Respondent $(s)(n)$ \\
\hline 1: parents' meetings + telecommunication & $\begin{array}{l}\text { Keeping distance } \\
\text { (see Figure 4) }\end{array}$ & 13.2 & 193 \\
\hline 2: only parents' meetings & $\begin{array}{l}\text { Unifacial } \\
\text { (see Figure 5) }\end{array}$ & 28.8 & 172 \\
\hline $\begin{array}{l}\text { 3: pre-arranged meetings + parents' } \\
\text { meetings + telecommunication + } \\
\text { consulting hours + home visit }\end{array}$ & $\begin{array}{l}\text { Agreed } \\
\text { (see Figure 6) }\end{array}$ & 11.8 & 152 \\
\hline 4: informal meetings & $\begin{array}{l}\text { Spontaneous } \\
\text { (see Figure 7) }\end{array}$ & 10.4 & 275 \\
\hline 5: parents' meetings + informal meetings & $\begin{array}{l}\text { Flexible } \\
\text { (see Figure 8) }\end{array}$ & 9.1 & 116 \\
\hline 6: consulting hours + parents' meetings & $\begin{array}{l}\text { Formal } \\
\text { (see Figure 9) }\end{array}$ & 18.8 & $\begin{array}{l}\text { Adaptive } \\
\text { (see Figure 10) }\end{array}$ \\
\hline $\begin{array}{l}\text { 7: telecommunication + consulting hours } \\
+ \text { parents' meetings }\end{array}$ & 7.9 & \\
\hline
\end{tabular}

Below, we review certain clusters and their features. 
Figure 4 - The patterns of contact: Keeping distance

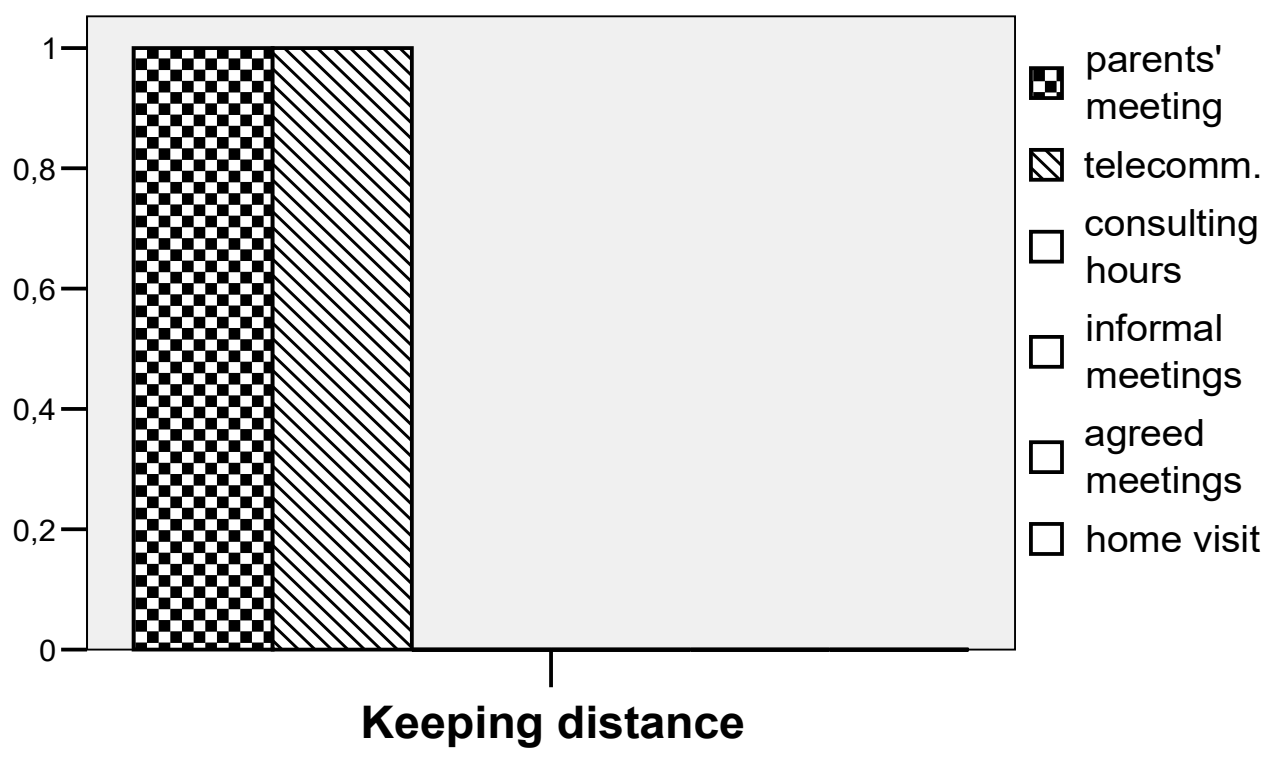

In Cluster 1, named 'Keeping distance', are parents who usually go to parents' meetings and keep in touch with the teacher by telecommunication methods. In this cluster there is no personal and close relationship, since there is no possibility to talk in private and spend enough time to talk about the child.

Figure 5 - The patterns of contact: Unifacial

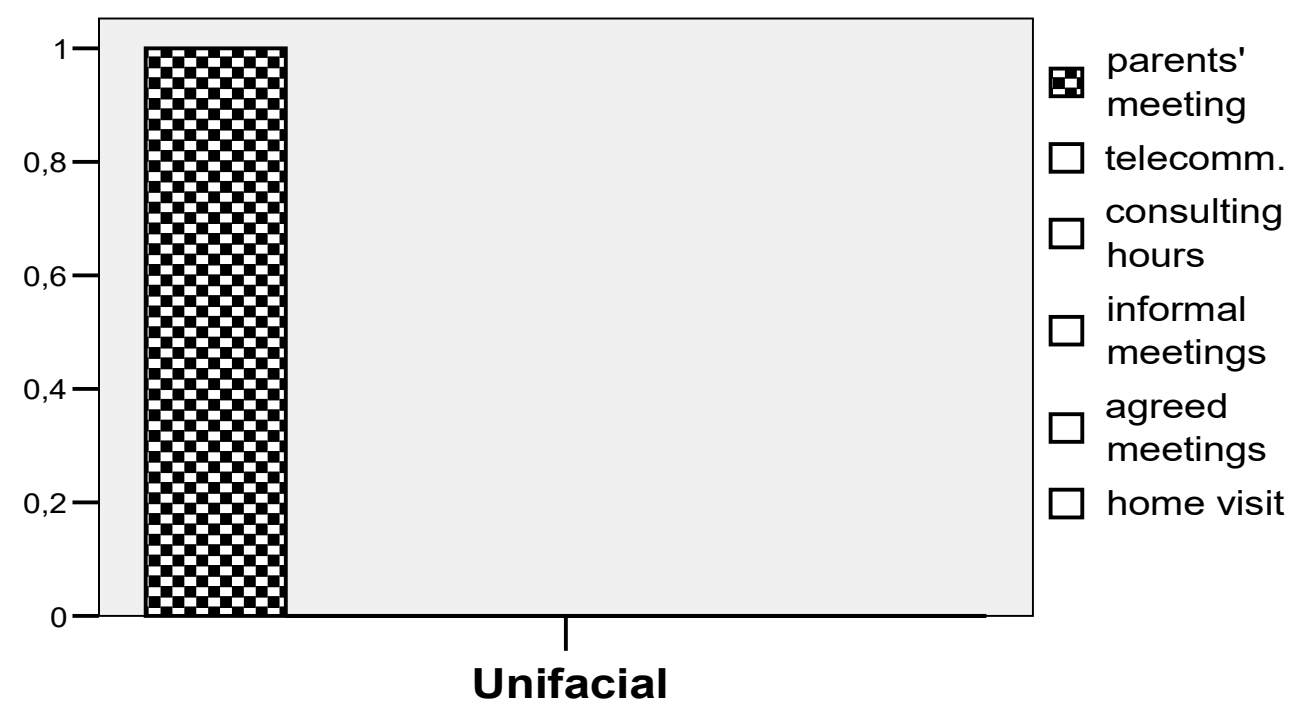

In Cluster 2, called 'Unifacial', are parents who only go to parents' meetings. They do not make the most of the opportunities presented to them, and their contact with the teacher is minimal. There is no personal interview, nor flexibility and adaptivity in the relationship. 


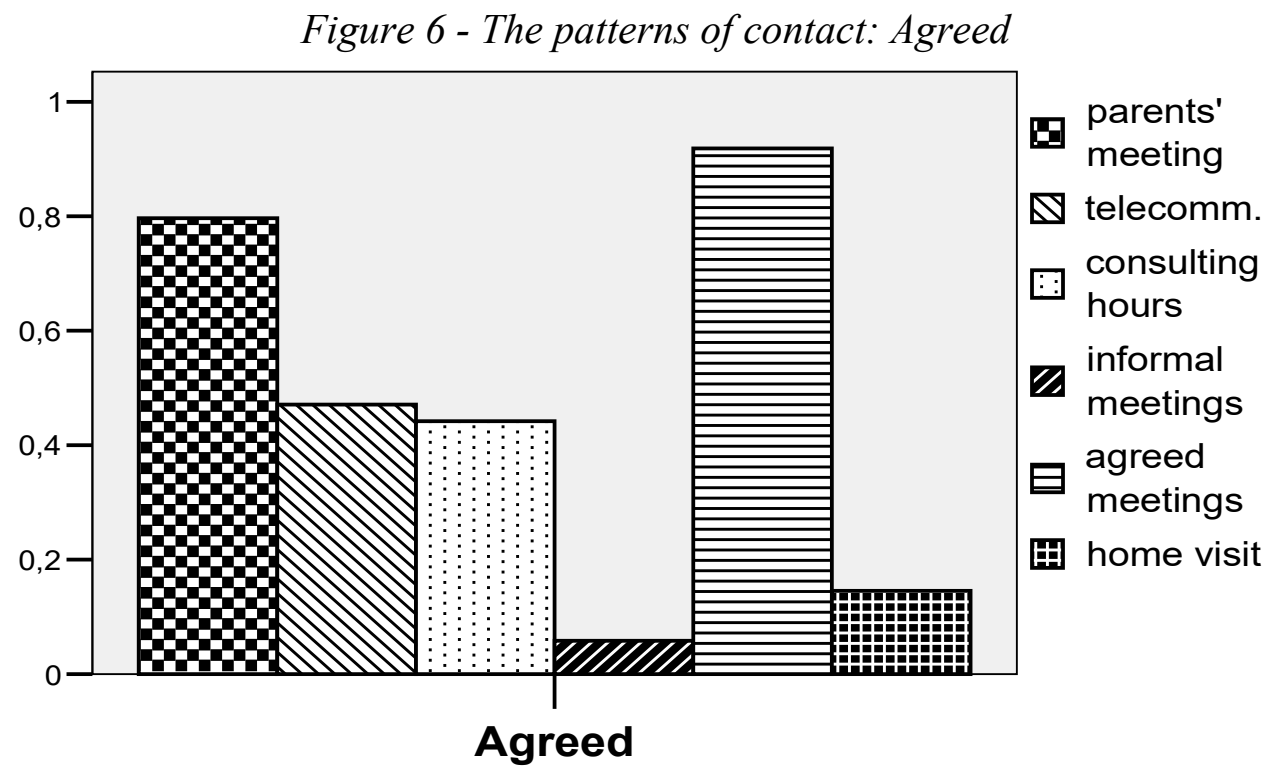

Cluster 3, named 'Agreed' because fixed appointments only occur in this cluster, represents the typical form of contact for $90 \%$ of parents. Family visits also only occur here, but do not exceed $20 \%$. $80 \%$ of parents attend parents' meetings in this cluster, and there are parents who take the opportunity and use telecommunication methods and consulting hours. We can probably include in this cluster parents who are invited in by the teacher. The teacher makes the appointment or visits the family. This assumption is reinforced by the fact that these parents reported significantly more symptoms related to their children, so here we can find parents of 'problematic children'. Of course, the parents may also initiate the appointment.

Figure 7 - The patterns of contact: Spontaneous

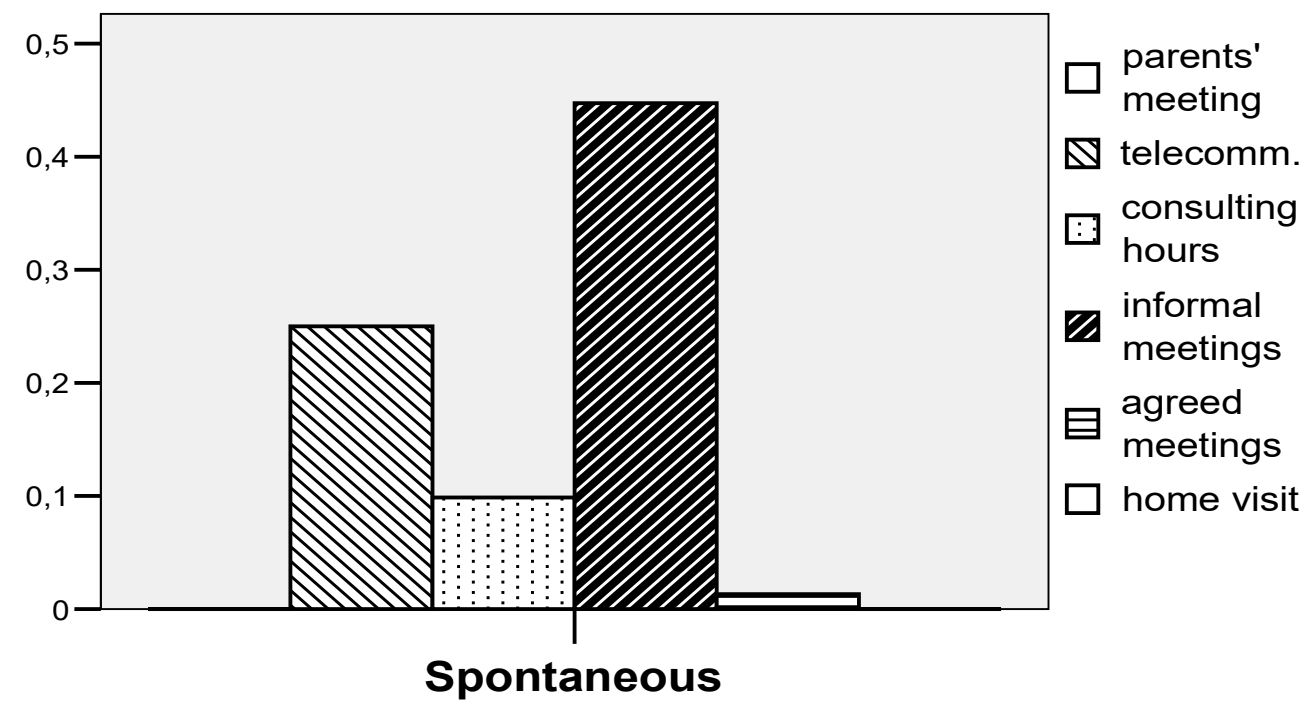

Analysing Cluster 4 ('Spontaneous'), we can see that parents do not go to parents' meetings at all. Other possibilities were less used by these parents than by others. Informal meetings and telecommunication methods are the most typical forms used to keep in touch, although they do not reach $50 \%$ on the scale. Examining this cluster in more detail, we found that it is 
less homogeneous than the others. In this cluster there are 152 parents, $40 \%$ of whom do not have contact by informal meeting, nor by telecommunication method, so essentially not at all. $35 \%$ of them keep contact informally, $20 \%$ by phone or by e-mail, and $5 \%$ use both forms.

Figure 8 - The patterns of contact: Flexible

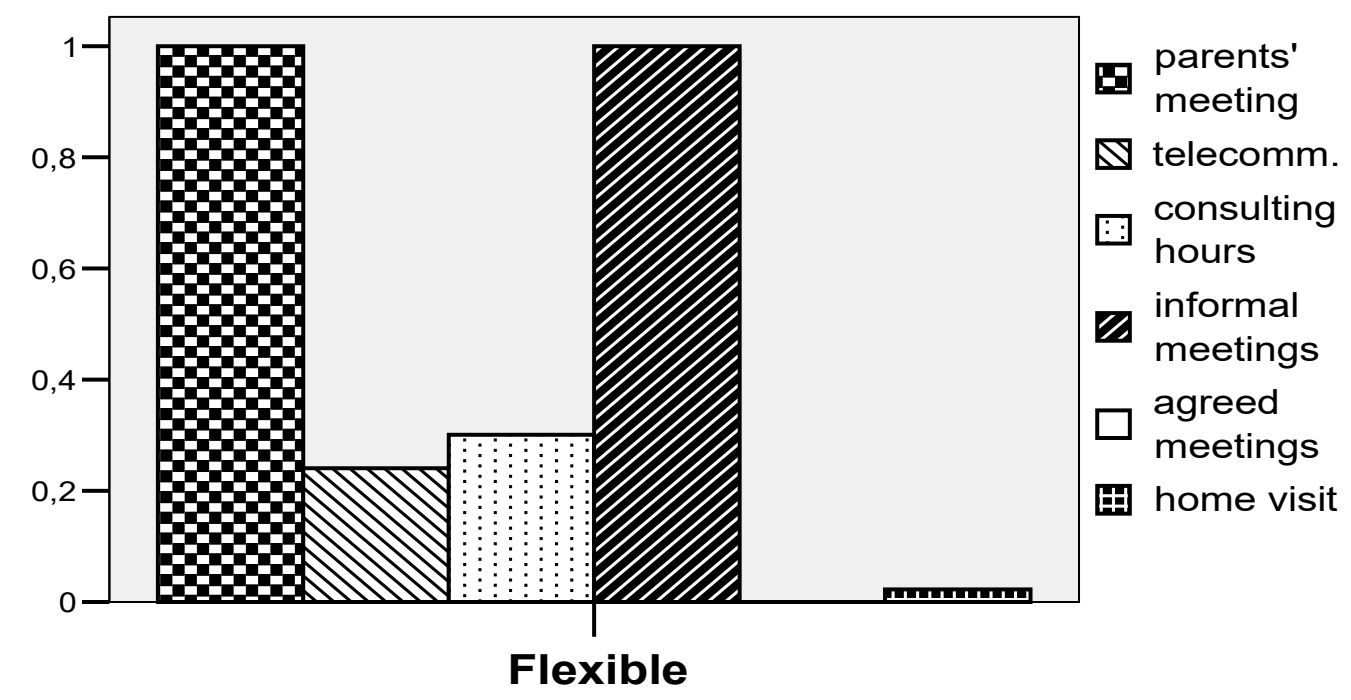

Cluster 5 is labelled 'Flexible', because besides parents' meetings, a full range of informal meetings occur, so these parents know they can visit the teacher at any time. They are involved in school life because of their collective interest in the parents' meetings, and are also linked to the teacher through the option of informal meetings.

Figure 9 - The patterns of contact: Formal

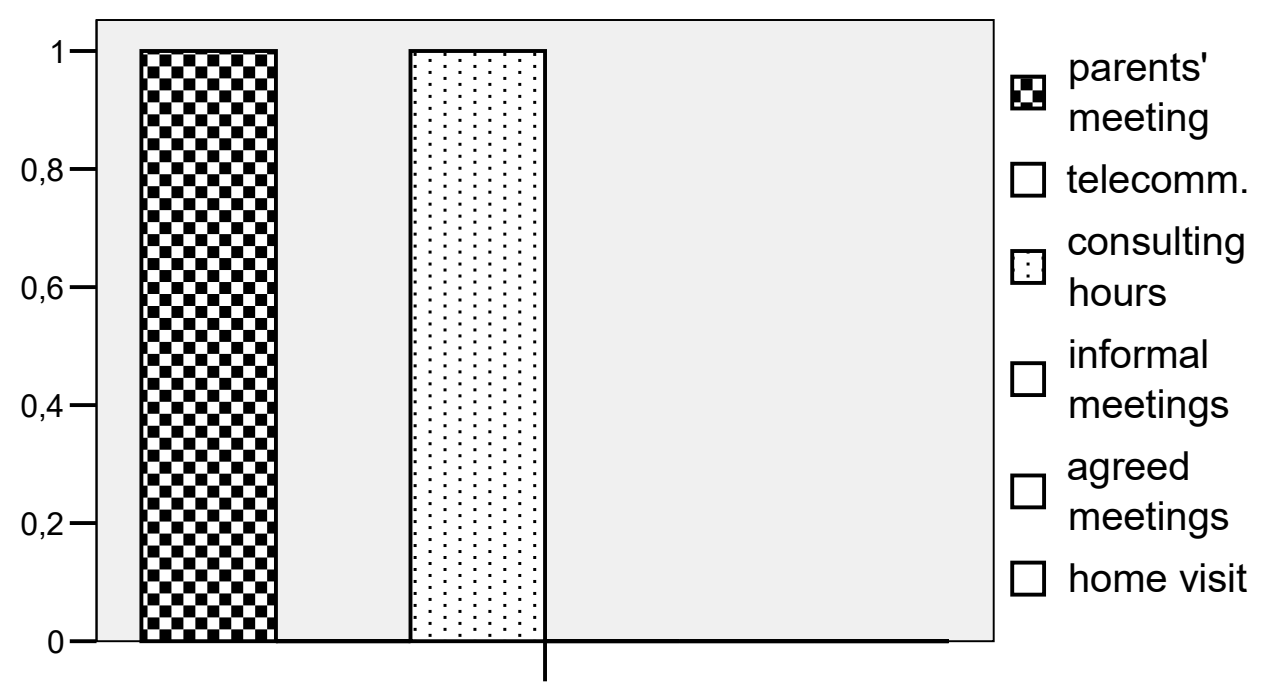

Formal

In Cluster 6, named 'Formal', we can find parents who only use traditional, formal types of contact: they usually go to parents' meetings, and consulting hours, but do not take advantage 
of other flexible forms of keeping contact. They tend to use only those options organized by the school.

Figure 10 - The patterns of contact: Adaptive

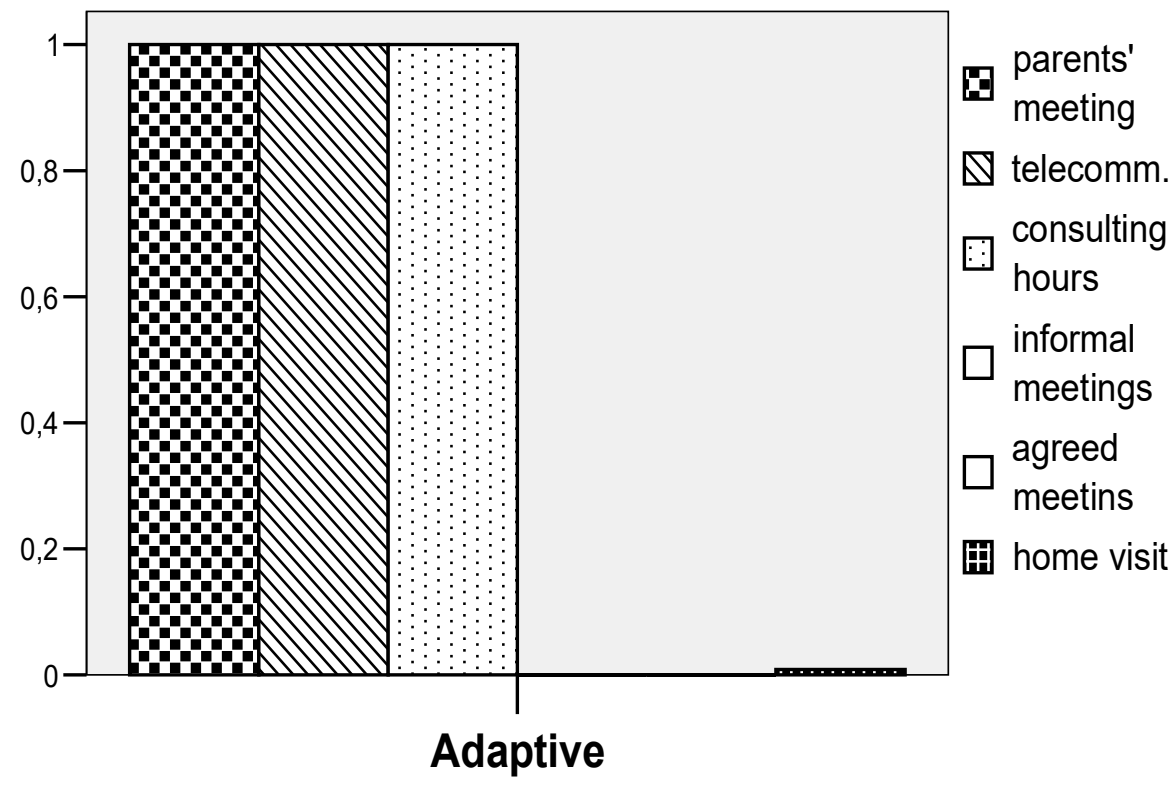

Cluster 7, labelled 'Adaptive', combines tradition, personal contact and flexibility. Parents' meetings offer the possibility to inquire about questions regarding the class; during consulting hours parents can talk in private about their child and if they need to they can get information by phone and e-mail in a quick and flexible way. In this cluster the relationship is animated and varied.

These seven clusters were each compared to the other variables which measured the quality of the relationship between parents and teachers. We found that in most cases the order was similar. The results of the Kruskal-Wallis test reached significance $(p=0.000)$ between five variables: the satisfaction with the types of contact, the quality of that contact, the frequency of contact and the satisfaction with the frequency of contact, and the level of cooperation when a problem occurs.

The 'Flexible' and 'Adaptive' forms reached the highest scores on this scale. Moderate scores were achieved by 'Keeping distance', 'Spontaneous' and 'Agreed' patterns of contact in terms of the variables above. The lowest scores were registered with two patterns of contact: 'Formal' and 'Unifacial', so parents are less satisfied with these clusters both in terms of quality and quantity. However, it is indeed thought-provoking that these forms are used by almost half of parents $(47.6 \%)$.

When considering frequency of contact, the order changes: in first place, there are two clusters, 'Flexible' and 'Spontaneous', so the 'Spontaneous' cluster moved up from a moderate score to a higher one. This probably only represents a possibility, i.e., that parents can visit a teacher at any time. However, we could see in the case of the 'Spontaneous' cluster that parents make least use of relationship possibilities in this cluster. The 'Adaptive' cluster lies in the middle range, while the order of the other clusters is the same.

In the case of emotional quality, in first place there are three clusters, 'Spontaneous', 'Adaptive' and 'Flexible'. Each has the same characteristics, i.e. personal and cooperative contact. 
There was no significant correlation in the case of equality, but we can find the same trend, especially regarding the 'Flexible' and 'Adaptive' clusters.

So when parents only go to the parents' meeting or consulting hours, this is the least beneficial of all forms of contact in terms of the relationship. The quality of contact is neither adequate nor frequent enough. These parents are less satisfied with the form and type of contact and they consider problem solving to be the least efficient. This result is very important, because $47.6 \%$ of parents are in this cluster. So more subtle analysis can reveal the dissatisfaction and the lack of contact behind the superficial 'everything is all right' answers given in the case of traditional and formal contact forms.

The parent most satisfied with contact are those who supplement parents' meetings with informal contact or consulting hours and telecommunication, and consequently fall into the 'Flexible' and 'Adaptive' cluster. Traditional settings are needed, but these should be complemented with newer, more flexible, and more private opportunities for contact. The aim of parents' meetings is to inquire about questions concerning the class (ideally in the form of a dialogue), planning and executing collective goals and tasks, answering questions which concern everyone, and problem solving. Personal questions are not relevant here, and special settings need to be created for these. Holding consulting hours in itself is not enough, especially in the strict and formal settings currently typical in schools.

Our first hypothesis was confirmed: frequent and flexible contact possibilities were considered more positive by parents, and this helps to create successful cooperation and to solve any problems that have occurred.

The relationship between children's behavioural symptoms and seven clusters of parentteacher contact and other variables was analysed. The Kruskal-Wallis test $\left(p<0.01^{* *}\right.$ and $\mathrm{p}<0.05^{*}$ ) revealed a significant relationship between the seven clusters of parent-teacher contact and all children's behavioural symptoms. The results are presented in the chart below, where we can see which contact patterns contain the most and the fewest children's behavioural symptoms.

Table 3 - Relationship between the patterns of contact and CBCL scores

\begin{tabular}{|l|l|l|}
\hline Scales of the CBCL & $\begin{array}{l}\text { The highest scores on the } \\
\text { CBCL (the most symptoms } \\
\text { occurring) }\end{array}$ & $\begin{array}{l}\text { The lowest scores on the } \\
\text { CBCL (the fewest } \\
\text { symptoms occurring) }\end{array}$ \\
\hline $\begin{array}{l}\text { Problems with social connection } \\
\text { scale** }\end{array}$ & $\begin{array}{l}\text { Spontaneous } \\
\text { Keeping distance }\end{array}$ & $\begin{array}{l}\text { Adaptive } \\
\text { Flexible }\end{array}$ \\
\hline Anxiety, depression scale* & $\begin{array}{l}\text { Agreed } \\
\text { Spontaneous }\end{array}$ & Adaptive \\
\hline Somatization scale* & Agreed & $\begin{array}{l}\text { Flexible } \\
\text { Adaptive }\end{array}$ \\
\hline Attention deficit scale** & $\begin{array}{l}\text { Agreed } \\
\text { Spontaneous }\end{array}$ & $\begin{array}{l}\text { Flexible } \\
\text { Adaptive }\end{array}$ \\
\hline Deviant behaviour scale** & $\begin{array}{l}\text { Agreed } \\
\text { Keeping distance }\end{array}$ & $\begin{array}{l}\text { Flexible } \\
\text { Adaptive }\end{array}$ \\
\hline Agressivity scale** & $\begin{array}{l}\text { Agreed } \\
\text { Keeping distance }\end{array}$ & $\begin{array}{l}\text { Flexible } \\
\text { Spontaneous }\end{array}$ \\
\hline Internalization* & Agreed & $\begin{array}{l}\text { Adaptive } \\
\text { Flexible }\end{array}$ \\
\hline Externalization $* *$ & Spontaneous & Flexible \\
\hline Total value of problems $* *$ & Agreed & $\begin{array}{l}\text { Adaptive } \\
\text { Flexible }\end{array}$ \\
\hline
\end{tabular}


The children with lowest levels of behavioural problems were those whose parents prefer 'Adaptive' and/or 'Flexible' patterns of contact, as was shown earlier. Consequently, we can affirm that the patterns of contact which were considered positive by parents really are more effective, considering that children have less psychological symptoms where parent-teacher contact works well and can adapt flexibly and efficiently,

Unequivocal tendencies can also be shown for contact patterns which are typical of parents whose children have various behavioural symptoms. The most typical form is 'Agreed'. As I mentioned earlier, in this cluster we can find those parents who are invited in to school by the teacher, or where the teacher makes the appointment or visits the family if there is a problem. It is only when the child has problems with their social relationships (conformity troubles, solitude) that we do not encounter this form of contact, perhaps because it may appear a less acute problem to the teacher. The 'Agreed' form also includes those parents who initiate the appointment, especially when a problem or symptom occurs.

The other form which is typical of parents who experience problems is 'Keeping distance', i.e. when parents usually go to parents' meetings and keep contact with the teacher by telecommunication methods. In this case our investigation does not reveal who initiates the contact, the parent or the teacher (in my experience, in most cases it is the parents who make the first phone call). This group probably includes parents who make do with parents' meetings when there is no problem with the child. When a problem occurs, they get in touch with the teacher. However, personal contact, where they could spend time talking about their child's problem, is not typical. This result is confirmed by teachers' experience that "the parents who really should take part in the parents' meetings are the ones who don't'.

The 'Spontaneous' contact form is also the typical form of parents whose children have several interiorization symptoms. It seems that the child's internal problems - which are less disturbing for the surroundings - do not force the teacher or the parents to make and maintain contact.

Our second hypothesis was confirmed: when parent-teacher forms of contact are more sufficient, children have fewer behavioural problems. Our results agreed with the observations of Füle (2002), Szabó (2003), Hegedüs and Podráczky (2012), and Lannert and Szekszárdi (2015).

Other variables of parent-teacher contact were examined with the Kruskal-Wallis test $\left(\mathrm{p}<0.01^{* *}\right.$ and $\left.\mathrm{p}<0.05^{*}\right)$ which revealed a strong significant relationship between the occurrence of children's symptoms and the quality of parent-teacher contact, the satisfaction with the form and frequency of the contact, the cooperation when a problem occurs and the equality of the contact.

The better the parents considered the quality of contact between themselves and teachers, and the more satisfied they were with its form and frequency, the fewer symptoms were mentioned, and vice versa: the less satisfied they were with the contact, the more symptoms occurred.

This confirms our third hypothesis, that the children of parents who have more positive contact with teachers have fewer behavioural problems. Parents who feel the contact to be a subordinate-superior one reported several symptoms in their children, although these did not include anxiety and interiorization symptoms. There was no significant correlation in the case of the frequency and the emotional quality of the contact. 
KÜLÖNLEGES BÁNÁSMÓD, III. ÉVF. 2017/1.

Table 4. Relationship between the parent-teacher contact and CBCL scores

\begin{tabular}{|l|r|r|r|r|r|}
\hline CBCL scales & $\begin{array}{l}\text { Nature of the } \\
\text { parent-teacher } \\
\text { contact }\end{array}$ & $\begin{array}{l}\text { Satisfaction } \\
\text { with the form } \\
\text { of the contact }\end{array}$ & $\begin{array}{l}\text { Satisfaction } \\
\text { with the } \\
\text { frequency of } \\
\text { the contact }\end{array}$ & $\begin{array}{l}\text { Cooperation } \\
\text { when a } \\
\text { problem } \\
\text { occurs }\end{array}$ & $\begin{array}{l}\text { Equality of } \\
\text { the contact }\end{array}$ \\
\hline $\begin{array}{l}\text { Problems with the } \\
\text { social connection } \\
\text { scale }\end{array}$ & $0.000^{* *}$ & $0.000^{* *}$ & $0.000^{* *}$ & $0.000^{* *}$ & $0.028^{*}$ \\
\hline $\begin{array}{l}\text { Anxiety. } \\
\text { depression scale }\end{array}$ & $0.047^{*}$ & $0.000^{* *}$ & $0.000^{* *}$ & $0.000^{* *}$ & 0.386 \\
\hline $\begin{array}{l}\text { Somatization } \\
\text { scale }\end{array}$ & $0.022^{*}$ & $0.004^{* *}$ & $0.002^{* *}$ & 0.160 & $0.003^{* *}$ \\
\hline $\begin{array}{l}\text { Attention deficit } \\
\text { scale }\end{array}$ & $0.000^{* *}$ & $0.000^{* *}$ & $0.000^{* *}$ & $0.000^{* *}$ & $0.046^{*}$ \\
\hline $\begin{array}{l}\text { Deviant } \\
\text { behaviour scale }\end{array}$ & $0.000^{* *}$ & $0.002^{* *}$ & $0.000^{* *}$ & $0.000^{* *}$ & $0.036^{*}$ \\
\hline Agressivity scale & $0.000^{* *}$ & $0.011^{* *}$ & $0.001^{* *}$ & $0.000^{* *}$ & $0.031^{* *}$ \\
\hline \begin{tabular}{l} 
Internalization \\
\hline Externalization
\end{tabular} & $0.000^{* *}$ & $0.000^{* *}$ & $0.000^{* *}$ & $0.000^{* *}$ & 0.119 \\
\hline $\begin{array}{l}\text { Total value of } \\
\text { problems }\end{array}$ & $0.000^{* *}$ & $0.001^{* *}$ & $0.000^{* *}$ & $0.000^{* *}$ & $0.010^{* *}$ \\
\hline
\end{tabular}

$\mathrm{p}<0.01^{* *} \mathrm{p}<0.05^{*}$

Examining these results from another point of view, we can suppose that parents whose children have fewer symptoms can have better contact with the teacher, since their contact is not hampered with problems, or symptoms that need to be solved, while parents whose children have difficulties considered contact with the teacher much less satisfying.

\section{DISCUSSION}

In view of the results obtained, we can confirm that parent-teacher contact is far from perfect, but it is absolutely necessary to improve it and make it function better. This is even more important, since it seems that the contact between adult authority figures and the way they can cooperate and find solutions when a problem occurs, influences children's mental health and the development of their symptoms. In terms of the practical aspects of school life, we emphasise three main points.

\section{Considering parents' contact patterns during cooperation.}

In our study we found seven patterns of contact. Of these, parent groups who are able to supplement traditional contact forms with more flexible and more private contact possibilities are more satisfied with the form of contact, its frequency, its quality and the level of cooperation when a problem occurs.

This distribution facilitates a more subtle analysis, since the everyday dichotomy (maintain contact / not maintain contact) could change, because there are clearly parents, especially in the younger age group, who are not content with the conventional, rigid forms offered by the school. In schools where there is no other possibility to contact the teacher, parents probably do not maintain any contact, or they are dissatisfied with it. Other possibilities to contact the teacher do exist, however, so if a good, personal relationship were to develop, there is a greater chance they would be more motivated to maintain contact in other ways, too. 
In whatever case, it would be preferable if more parents used personal methods, instead of formal, impersonal, rigid forms of contact. Conventional forms should be reviewed and 'reformed', and alternative forms should be introduced (Szabó, 2006).

The frequency of contact correlates with satisfaction with cooperation, too. This draws attention to the fact that more frequent communication possibilities need to be made available to parents, and it points to the fact that if parents can make positive contact with the teacher, the contact will be more frequent.

Necessarily, the quality of all human relationships depends on both parties; however, in this context the teacher's role, qualifications, and experience are the main factors which can provide a starting point for change and improvement. It is necessary to acquire an approach in which parent-teacher contact is equal and based on cooperation, and to work towards a common goal (the education and welfare of the child).

It is very helpful if a parent has an outstanding ability to build relationships, and has excellent communication and conflict management skills - however, this cannot be an expected requirement. We are, however, justified in expecting that the teacher has these abilities. It is essential that teachers are able to self-monitor and improve their self-awareness in order to recognize the situation adequately and deal with it.

\section{Teacher training}

Here we move on to discuss another aspect which is emphasized by our results. Teacher training (and in-service training) institutions have a significant role in change, since cooperation with parents and review of conventional forms of contact still only have a minor role in teacher training. This problem is not unique to Hungary; there are only a few teacher training programmes in Europe which help prepare teachers to keep in touch with parents (Salamon, 2013).

\section{Experts assisting in the school}

Ideally, teacher developers, speech therapists and school psychologists (most frequently) are present in primary schools to help children who have various symptoms and problems, and their parents. Our results reveal that children's symptoms cannot be treated in isolation. It is necessary to monitor the relationship between the parents and teachers, and to give specialist assistance to improve it (and mediate where necessary).

The increasing use of team-work in schools must be encouraged, and supervision groups must be made a regular feature of school life, so that a child and his/her family do not only contact a teacher when a problem occurs. Teacher-parent groups should be established, in which both parents and teachers can talk, discuss their opinions, and learn the skills required for successful co-operation.

\section{REFERENCES}

F. Lassú, Zs., Podráczky J., Glauber A., Perlusz, A. \& Marton, E. (2012). Nemzetközi kutatások a szülői részvétel hatásáról. In Podráczky J. (szerk.): Szövetségben. Tanulmányok a család és az intézményes nevelés kapcsolatáról. ELTE Eötvös Kiadó: Budapest. 13-42.

Füle, S. (2002). Párbeszéd a szülök és a pedagógusok között. Okker Oktatási, Kiadói és Kereskedelmi Kft: Budapest.

Gádoros, J. (2007). Gyermekviselkedési Kérdőív. Child Behavior Checklist, CBCL, Achenbach, 1991). In: Perczel Forintos, D., Kiss, Zs. \& Ajtay, Gy. (szerk.): Kérdöívek, 
becslöskálák a klinikai pszichológiában. Országos Pszichiátriai és Neurológiai Intézet: Budapest. 130-137.

Hegedűs, J. és Podráczky, J. (2012). Fókuszcsoportos beszélgetések a közoktatási intézmény és a család kapcsolatáról - első reflexiók a kutatás kapcsán. In: Podráczky, J. (szerk.): Szövetségben. Tanulmányok a család és az intézményes nevelés kapcsolatáról. ELTE Eötvös Kiadó: Budapest. 105-124.

Hunyady, Gy. (2002). Iskola-imázs. Iskolakultúra, 12.4. sz. 29-39.

Katona, N. és Szitó, I. (2005). Szerepkonfliktusok felismerése és kezelése a pedagógus-szülö kapcsolatban. Mester és Tanitvány 2.7. sz. 47-59.

Lannert Judit, Szekszárdi Júlia (2015). Miért nem érti egymást szülő és pedagógus? Iskolakultúra, 25.1. sz. 15-34.

Lénárd, S. (2003). Naiv nevelési nézetek. Iskolakultúra, 13.5. sz. 76-82.

Salamon, E.: A szülők bevonása mint az iskolai siker kulcsa. (Download: 2015.06.02.). (Web: http://www.osztalyfonok.hu/cikk.php?id=1246.

Szabó, É. (2006). Szeretettel és szigorral. A iskolai nevelés problémái a szülök és a tanárok szemszögéből. Akadémiai Kiadó: Budapest.

Torgyik, J. (2009). Jó gyakorlatok a multikulturális nevelés köréből. In: Kállai, E. és Kovács, L. (szerk.): Megismerés és elfogadás. Pedagógiai kihívások és roma közösségek a 21. század iskolájában. Nyitott Könyvmühely Kiadó: Budapest. 31-41.

Vámos, Á. (2001). A metafora felhasználása a pedagógiai fogalmak tartalmának vizsgálatában, Magyar pedagógia, 101.1. sz. 85-108.

Winkler, M. (2003). Iskolapélda. Kinek kaloda, kinek fészek. Edge $2000 \mathrm{Kft}$ : Budapest.

2011. évi CXC. törvény a nemzeti köznevelésröl 


\title{
ADOLESCENTS' HEALTH BEHAVIOUR ACCORDING TO SPORT AND FAMILY STRUCTURE ${ }^{2}$
}

\author{
Authors: \\ Karolina Eszter Kovács \\ University of Debrecen \\ Beáta Erika Nagy \\ University of Debrecen
}

\author{
Lectors: \\ Tamás Józsa \\ University of Debrecen \\ Barnabás Szilágyi \\ University of Debrecen \\ Ferenc Mező \\ Eszterházy Károly University \\ Edina Szabó
}

E-mail address of the first author:

karolina92.kovacs@gmail.com

Kovács, Karolina Eszter and Nagy, Beáta Erika (2017): Adolescents' health behaviour according to sport and family structure. Különleges Bánásmód, III. évf. 2017/1. szám, 27-37. DOI 10.18458/KB.2017.1.27

\begin{abstract}
Health awareness plays an important role in our life. It's important to live an appropriate lifestyle because adequate way of life helps to conserve the optimal health status and to prevent chronic diseases (Conner, 2005). The role of the family and parents is still significant. Children turn toward their peers but the family stands in the background as a supporting basis (Kovács \& Pikó, 2009). However this function cannot be fulfilled with the crisis and disintegration of family structure which can mean a serious stressor, so it can increase the appearance and in serious case the longlasting subsistence of harmful health behaviour (Bramlett \& Blumber, 2007). The aim of the study is to measure the appearance of smoking, getting drunk and substance use depending on sport and family structure in three counties on the basis of FASCES 2015. According to the results only pursuing sport does not influence the testing rate but it can be seen as a protective factor. Family structure considered on its own is not a significantly influencing factor but the mediating role of social factors are well perceptible in case of smoking, getting drunk and using weed.
\end{abstract}

Keywords: adolescence, sport, family, health-risk behaviour

Disciplines: educational science, psychology

\footnotetext{
${ }^{2}$ The editorial board does not take any responsibilty for the English of the papers. Indeed, we made some slight changes but wanted to keep the style of the authors.
} 


\section{Absztrakt}

$\mathrm{Az}$ egészségtudatos életvitel meghatározó tényező egészségi állapotunk tekintetében, kiemelkedő szereppel bír az optimális egészségi állapot megőrzésében és a krónikus betegségek megelőzésében egyaránt (Conner, 2005). A család és a szülők szerepe még jelentős; a gyermekek egyre inkább kortársaik felé nyitnak, ám a család támogató bázisként ott matad a háttérben (Kovács \& Pikó, 2009). Ugyanakkor a családban bekövetkező krízis okán nem tud teljesülni ez a funkció, s komoly stressz forrást jelent a fiatal számára, növelve az egészségkárosító magatartásformák kipróbálásának vagy akár hosszú távú fennmaradásának esélyét (Bramlett \& Blumber, 2007). Kutatásunk célja a dohányzás, lerészegedés, valamint illegális szerhasználat kipróbálását, valamint a sportolást vizsgáljuk meg 10. osztályos tanulók körében három megyében, a FASCES-OKM 2015 alapján.

Az eredmények alapján a sportolás önmagában nincs jelentős hatással a vizsgált változókra, ugyanakkor protektív tényezőként tekithető. A családszerkezet sem számít szignifikánsan befolyásoló tényezőnek önmagában véve, ugyanakkor a társas faktorok mediáló szerepe jól látható a dohányzásban, alkoholfogyasztásban és füvezésben egyaránt.

Kulcsszavak: Serdülőkorúak, sport, család, egészségkárosodás

Diszciplína: neveléstudomány, pszichológia

\section{RISK-TAKING IN ADOLESCENCE}

Regarding health-risk behaviours, adolescence is the most risky period as the frequency of these is growing while the health protecting behaviour is decreasing (Lohaus et al, 2009). The common characteristic of different kind of risky behaviours (e. g. alcohol consumption, substance use, smoking or promiscuity) is that young people think on these as an adult thing which makes them attractive.

Some kind of risk-taking and health-risk behaviours have positive effects in short-term as alcohol consumption, substance use or smoking can have a relaxing effect, reduce temporarily anxiety and entails with peasant mood. The high prevalence of harmful habits can be caused by these facts which can be a huge motivator in adolescence as well. Thus one aspect of risktaking is the discretion whether it is worth the short-term enjoyment namely the health awareness is in connection with future orientation (Rothspan \& Read, 1996). The choice of actual advantages is typical in this life period, ignoring the long-term health advantages (Goldberg et al, 2002). Otherwise, the tryout is not necessarily maladaptive in adolescence as health-risk behaviour can be one source of psychosocial development which has a health protective function: integration to peer groups, rebellion against the authority or compensation (Brassai, 2010). In this meaning, this cannot be regarded obviously harmful in psychological aspect if the adolescent experience the short-term advantages. It means a problem when the health-damaging behaviour endures for long.

The results of the researches on young people's health behaviour are getting more worrisome year by year: the usage of harmful habits and regular sexuality is beginning earlier and has a broader scope (Csizmadia \& Várnai 2003; Németh 2003; Sebestyén 2003) and the prevalence of psychosomatic symptoms is abnormally high among young people (Susánszky \& Szántó 2002).

One of the biggest sources of danger is smoking; the rate of smoking is really high in domestic population. It can be said according to the results of HBSC (Health Behaviour in School-aged children) in 2010, that the prevalence of the tryout of smoking is higher with the age. $14,5 \%$ of children in the $5^{\text {th }}$ class said that they have ever tried out smoking while $76,8 \%$ of them have tried it out in $11^{\text {th }}$ class. It is more likely for boys in every age bracket but the 
rate almost will be compensated in secondary level (Németh \& Költö, 2011). Unfortunately, the rate of regular smokers (at least in every week) is growing with the age. In $5^{\text {th }}$ class, 3,5\% of boys and $1 \%$ of girls said that they are regular smokers but in $7^{\text {th }}$ class the rate was $8,8 \%$ among boys and $6,7 \%$ among girls. After this a sharp increase can be seen as in $9^{\text {th }}$ class $29,6 \%$ of boys and $26 \%$ of girls while in $11^{\text {th }}$ class $41,5 \%$ of boys and $33,8 \%$ of girls can be regarded as regular smokers (Németh \& Költö, 2011).

Beside smoking, alcohol consumption is also a huge problem; according to the results of HBSC, trying out alcohol often happens early. $30 \%$ of children in the $5^{\text {th }}$ class have ever consumed alcohol namely $44 \%$ of boys and $30,5 \%$ of girls. The difference in the tryout of alcohol among boys and girls is significant in primary school however this difference disappears in secondary school. In the $9^{\text {th }}$ class, $86,3 \%$ of boys and $83,9 \%$ of girls said that they have ever consumed alcohol while in the $11^{\text {th }}$ class the rate is $91,3 \%$ among boys and $90,6 \%$ among girls. It can be said regarding the consumption frequency that the rate of consumption is significantly higher among older children (Németh \& Költő, 2011).

Illegal substance use needs to be mentioned among harmful habits. In Hungary, the results of drug consumption are worrisome as well. HBSC in 2010 showed that almost one third of children in $9^{\text {th }}$ and $11^{\text {th }}$ class have ever tried out some kind of illegal substance, medicine as misuse or some kind of inhalant. The rate of trying out is higher among boys as $29,7 \%$ of boys while $22,3 \%$ of girls have tried it out at $t$ least once in $9^{\text {th }}$ class and the rate is $38,4 \%$ among boys and $31,2 \%$ among girls in the $11^{\text {th }}$ class. Regarding drug consumption, the most frequency of trying out cannabis 1 or 2 times $(8 \%)$ as well as taking in medicines with alcohol $(7,2 \%)$ or alone $(3,4 \%)$ and amphetamines (speed) $(4,7 \%)$ showed the highest prevalence (Németh \& Költő, 2011).

\section{Sport and risky behaviour}

Unfortunately, the measure of regular physical activity is low in west societies however the positive effects of sport are well-known. The research of Hallal et al (2012, quote Smith et al., $2015)$ showed that approximately one third of adults $(31,1 \%)$ in physically inactive among adults (over 15 years old people) in 122 countries. This is a huge problem regarding sport -as in previous summary also can be seen- has several benefits. It was claimed too that active children will become significantly healthier and wealthier compared with inactive ones (Stevenson, 2010). It is important to learn habits of healthy lifestyle as early behaviour patterns are good predictors of latter behaviour (Ajzen, 2011, quote van Bree et al., 2015). Almost half of the Hungarian population sits or stands during the work (involving other activities as work beside the workplace e. g. housework, learning etc.). Only 4,5\% of the population does exercise every day while $67 \%$ of them does not pursue sport 10 minutes per day at all (ELEF, 2014).

According to national and international investigations, it can be said that physically active adolescents are more satisfied with their life and have less depressive symptoms compared with inactive ones (Pluhár és mts., 2004, idézi Pikó és Keresztes, 2007). Otherwise, those who pursue sport regularly (both on amateur and competitive level) feel healthier, are more resilient (Kovács, 2014) and are more satisfied with themselves (Kovács és Perényi, 2014).

The results of the researches on risky behaviours are ambivalent. One group of the investigations says that active young people have healthier nutrition and the risk of obesity is lower (Pate és mts, 1996; Steptoe és mts, 1997), live a more safety sexual life (Sabo és mts, 1999). They also have better mood compared with inactive people and the attribute themselves a better fitness and health status thus sporty behaviour parallels with better life quality (Pluhár és mts, 2004). In case of smoking, sport is a protective factor as the amount of smoking is lower among athletes (Burke és mts, 1997). However, there are other research results as well which showed a positive relation between sport and health-damaging 
behaviour including smoking, alcohol and drug consumption and promiscuity) (Faurie és mts, 2004). This is typical for competitive athletes first of all where the child would like to reduce the stress caused by the big pressure and achievement compulsion in some kind of way or it would like to improve its achievement. According to some researches, competitive athletes consume more alcohol and begin it earlier (Hildebrand és mts, 2001) therefore the emphasise need to be put on physical activity done by an appropriate way.

\section{The role of family in health-risk behaviour}

The role of family is indisputable in forming the adolescent's healthy and risky behaviour and health awareness (Pikó, 2005). This is the first social atmosphere which is a pattern for the child not only in childhood but in adulthood as well. Peer relationships are getting more and more important but family stands in the background as a support basis (Kovács és Pikó, 2009).

Family has different kind of protective role in regard of adolescents' health behaviour. More researches have investigated the effect of leisure time activities in connection of the parents which functions as a protective factor for the values and health awareness of the child (Brassai és Pikó, 2005). Those adolescents whose parents paid attention and controlled the leisure time activities of their children more consumed alcohol or drug less likely (Ford, 2009, Järvinen és Østergard, 2009, idézi Kovács és Pikó, 2009). Therefore, structural crisis in the family means a huge risk.

The forming of the family structure influences the individual's relation to its family, the strength of the relationship, the socialisation, the sense of security and social support as well (Kopp és Skrabski, 2001; Poortinga, 2006). Researches claim that changes in the structure of the family have a negative effect on health-conscious behaviour as the prevalence of risky and health-damaging behaviour is higher among children from non-intact families. The physiological and emotional development of children from single-parent families is worse and they commit in risky behaviours more (Bramlett és Blumber, 2007). The substance use is higher among these children (Barrett és mts, 2006; McArdle és mts, 2002) and the prevalence of early sexual experiences and pregnancy in adolescence is higher too (Bonnel és mts, 2006). The likelihood of smoking is the lowest in traditional two-parent families while among children from patchwork families is the highest (Griesbach, 2003). Pikó claims according to her research called "Youth investigation in the South Great Plain" that non-intact family structure has a negative influence on health-conscious behaviour as it is a risk factor; the appearance of psychosomatic and depression symptoms and the substance use is higher among children from these families. Hair et al (2009) explained that low-risk individuals which means the people who abstain from health-damaging and risky behaviour and are engaged in healthy behaviours comes mostly from traditional families.

Kovács and Pikó (2009) investigated the effect of family structure on health behaviour, smoking, alcohol and marihuana consumption among secondary grammar school students in Szeged. Their results showed that a significant difference can be shown according to the parents' family status as the prevalence of smoking was significantly lower among children from two-parent families while it was higher among children with structural crisis behind them. Common family meals have a positive effect on children's and adolescents' mental health although the amount of these reduces or disappears in case of a structural crisis (Compan és mts, 2002).

\section{The introduction of the investigation}

The aim of the investigation is to measure the different types of risky behaviours and the influential factors of the try-outs including family structure, sport and societal factors. The 
basis of the research was the FASCES 2015 database including 627 students from the $10^{\text {th }}$ class from Borsod-Abaúj-Zemplén, Szabolcs-Szatmár-Bereg and Hajdú-Bihar counties.

First we measured the differences between the differences according to the family structure. The results can be seen in Table 1 .

Table 1: The try-out of the different kind of health-risk behaviours in regard of family structure (person, percent) (Source: FASCES 2015)

\begin{tabular}{|c|c|c|c|c|c|c|c|c|c|c|c|}
\hline & & \multicolumn{2}{|c|}{ Smoking } & \multicolumn{2}{|c|}{$\begin{array}{c}\text { Getting } \\
\text { drunk }\end{array}$} & \multicolumn{2}{|c|}{ Weed } & \multicolumn{2}{|c|}{ Light drug } & \multicolumn{2}{|c|}{$\begin{array}{l}\text { Hard } \\
\text { drug }\end{array}$} \\
\hline & & Yes & $\mathrm{No}$ & Yes & $\mathrm{No}$ & Yes & No & Yes & $\mathrm{No}$ & Yes & $\mathrm{No}$ \\
\hline \multirow{2}{*}{$\begin{array}{l}\text { Traditional } \\
\text { family }\end{array}$} & $\mathrm{N}$ & 302 & 156 & 260 & 197 & & 393 & 25 & 432 & 0 & 446 \\
\hline & $\%$ & 65,9 & 34,1 & 56,9 & 43,1 & 14,0 & 86,0 & 5,5 & 94,5 & 2,0 & 98,0 \\
\hline \multirow{2}{*}{$\begin{array}{c}\text { Single-parent } \\
\text { family }\end{array}$} & $\mathrm{N}$ & 54 & 23 & 52 & 25 & 11 & 65 & 8 & 69 & 6 & 71 \\
\hline & $\%$ & 70,1 & 29,9 & 67,5 & 32,5 & 14,5 & 85,5 & 10,4 & 89,6 & 7,8 & 92,2 \\
\hline \multirow{2}{*}{$\begin{array}{c}\text { Restructured } \\
\text { family }\end{array}$} & $\mathrm{N}$ & 13 & 48 & 37 & 22 & 11 & 50 & 5 & 56 & 2 & 58 \\
\hline & $\%$ & 8,7 & 21,3 & 62,7 & 37,3 & 18,0 & 82,0 & 8,2 & 91,8 & 3,3 & 6,7 \\
\hline
\end{tabular}

According to the results of the One-way ANOVA it can be said that the try-out rate is the lowest among children from traditional family. These results show the holding function of the family and they also prove the fact that the safety family atmosphere is a protective factor against risky behaviours. According to the results, the try-out of getting drunk $(p=0,175)$, light drugs $(p=0,219)$ and hard drugs $(p=0,018)$ is the highest among children from single-parent families while the try-out of smoking $(p=0,121)$ and smoking weeds $(p=0,703)$ was the highest among children from restructured families. The differences were not significant only in case of hard drugs nevertheless they are awareness-raising as they show the tendency that the appearance of health-damaging behaviours is higher among children in whose family a structural crisis happened which means that these children are in more endangered situation compared with their peers from traditional families.

In the investigation, logistic regression analysis was used to measure what kind of factors influence the try-out of smoking, getting drunk and illegal substances (weed, light and hard drug). The factors involved into the investigation were classified into three groups namely family structure, pursuing sport and societal factors. Societal factors were gender, type of settlement (city/town or village), subjective financial status (under or over the average) and employment status of the parents'. The reference group was the group of children from traditional family as the try-out prevalence was the lowest among these children.

\section{Smoking}

In case of smoking it can be said that family structure the family structure itself does not have a significant effect on the smoking try-out and sport does not have a significant influence too. From the involved socio-demographical factors, gender, type of settlement and employment status of the parents didn't show a significant influence. However, subjective financial background shows a significant impact $(p=0,035)$ : those who have better financial background are more likely to try out smoking. Involving these social factors we can see that a significant effect is shown in living in restructured family: those who have this kind of crisis have a 2 times bigger chance to try-out smoking. The results of regression analysis can be seen in Table 2. 
Table 2: The results of logistic regression analysis on the try-out of smoking. (Source: FASCES $2015(N=614))$

\begin{tabular}{|l|r|r|r|}
\cline { 2 - 4 } \multicolumn{1}{c|}{} & Model 1 (ExpB) & Model 2 (ExpB) & \multicolumn{1}{c|}{ Model 3 (ExpB) } \\
\hline Single parent family & 1,213 & 1,200 & 1,536 \\
\hline Restructured family & 1,929 & 1,931 & $2,056^{*}$ \\
\hline Sport & & 0,865 & 0,892 \\
\hline Gender & & & 0,980 \\
\hline Financial background & & & $1,537^{*}$ \\
\hline Type of settlement & & & 0,893 \\
\hline Father's employment & & & 1,724 \\
\hline Mother's employment & & & 0,957 \\
\hline Constant & $1,987^{* * * *}$ & $2,032^{* * *}$ & 1,185 \\
\hline
\end{tabular}

${ }^{*} \mathrm{p}<0,05,{ }^{* *} \mathrm{p}<0,01, * * * \mathrm{p}<0,001$

Family structure and financial status influence the likelihood of smoking together. In case of financial status under the average, the try-out rate is lower among children from traditional families compared with their peers from families with some kind of family structure but in case of financial status over the average, the try-out rate is higher among children from traditional families. That is to say that the financial status under the average means a risk factor for children in non-intact families while the financial status over the average is a risk factor for children in traditional families. It can be said that the change in family structure improve the odds of the smoking try-out.

\section{Getting drunk}

In relation of alcohol consumption, we investigated the prevalence of the try-out of getting drunk. We also could say that neither family structure nor sport has a significant effect however socio-demographical factors have again a significant impact. It can be seen that gender $(p=0,001)$, type of settlement $(p=0,020)$, subjective financial status $(p=0,013)$ and the employment status of the father $(\mathrm{p}=0,022)$ had a significant effect on the try-out). The results of the logistic regression analysis can be seen in the Table 3 .

Regarding gender the appearance of getting drunk seemed to higher which means that males have higher likelihood to try out getting drunk which correlates to previous national and international results. With the involvement of gender, the differences according to the family structure were significant as well: the chance of getting drunk was significantly higher among boys from single-parent families $(75,8 \%)$ compared with the other groups (among boys from traditional families $66 \%$ and from restructured families $64,3 \%$ ). This is to say that children from single-parent families are in more endangered situation, even compared with peers from restructured families.

According to subjective financial status, it could be seen significant differences as well $(p=0,013)$. We can say that children who judge their financial background over the average have tried out getting drunk in higher prevalence $(66,8 \%)$ compared with their peers who judge their financial background under the average. This means that children living in better financial background are more endangered. 
Otherwise, the type of settlement also had a significant effect as the prevalence of trying out getting drunk was higher among adolescents who live in a village $(p=0,020)$ in all family types which means that children living in a village are more endangered.

Table 3: The results of logistic regression analysis on the try-out of getting drunk. (Source: FASCES 2015 (N=614))

\begin{tabular}{|l|r|r|r|}
\cline { 2 - 4 } \multicolumn{1}{c|}{} & Model 1 (ExpB) & Model 2 (ExpB) & \multicolumn{1}{c|}{ Model 3 (ExpB) } \\
\hline Single parent family & 1,512 & 1,502 & $2,145^{* * *}$ \\
\hline Restructured family & 1,360 & 1,362 & 1,746 \\
\hline Sport & & 0,916 & 0,854 \\
\hline Gender & & & $1,796^{* * *}$ \\
\hline Financial background & & & $0,651^{*}$ \\
\hline Type of settlement & & & $1,619^{*}$ \\
\hline Father's employment & & & $1,964^{*}$ \\
\hline Mother's employment & $1,323^{* * *}$ & $1,341^{* * *}$ & 1,457 \\
\hline Constant & & & 0,460 \\
\hline
\end{tabular}

${ }^{*} \mathrm{p}<0,05, * * \mathrm{p}<0,01, * * * \mathrm{p}<0,001$

Las but not at least, the effect of father's employment can be detected as a significant influential factor $(\mathrm{p}=0,022)$ as those whose father or stepfather works are more likely to try out this kind of risk-taking $(59,8 \%)$ compared with those whose father or stepfather does not work $(46,9 \%)$. This result shows that the unemployment of the father is a retentive factor.

In this model we also could see that with the involvement of socio-demographical factors the effect of living in a single parent family appeared as well as those who live in this type of family have a 2 times bigger chance to try out getting drunk.

\section{Smoking weeds}

The logistic regression analysis of trying out weeds showed similar results as it could be seen in case smoking. It can be said too that that neither family structure nor sport shows an obviously significant effect on the likelihood of trying out weeds, however, a tendency could be seen that the try-out rate is higher among children with a structural crisis (firstly in case of restructured families). The financial status showed a significant impact from the involved demographical variables as the values of both the children from single-parent families and restructured families deviate from the values of the children from traditional families but no obvious tendency can be detected in the background. The results of the logistic regression analysis can be seen in Table 4 .

\section{Light drugs}

In case of light drugs it can be said that neither family structure nor sport has a significant effect on the likelihood of the try-out. Furthermore, according to the results of the logistic regression analysis (Table 5) it can be said that any of involved demographical factors have a significant effect on the try-out of light drugs. 
Table 4: The results of logistic regression analysis on the try-out of smoking weeds. (Source: FASCES $2015(N=614))$

\begin{tabular}{|l|l|l|l|}
\cline { 2 - 4 } \multicolumn{1}{c|}{} & Model 1 (ExpB) & Model 2 (ExpB) & Model 3 (ExpB) \\
\hline Single parent family & 1,042 & 1,069 & 1,334 \\
\hline Restructured family & 1,397 & 0,397 & 1,441 \\
\hline Sport & & 1,320 & 1,353 \\
\hline Gender & & & 0,919 \\
\hline Financial background & & & 0,610 \\
\hline Type of settlement & & & $1,153^{*}$ \\
\hline Father's employment & & & 2,091 \\
\hline Mother's employment & & & 0,784 \\
\hline Constant & $0,168^{* * *}$ & $0,160^{* * *}$ & $0,126^{* * *}$ \\
\hline
\end{tabular}

$* \mathrm{p}<0,05, * * \mathrm{p}<0,01, * * * \mathrm{p}<0,001$

Table 5: The results of logistic regression analysis on the try-out of light drugs. (Source: FASCES $2015(N=614))$

\begin{tabular}{|l|l|l|l|}
\cline { 2 - 4 } \multicolumn{1}{c|}{} & Model 1 (ExpB) & Model 2 (ExpB) & Model 3 (ExpB) \\
\hline Single parent family & 1,961 & 1,917 & 1,852 \\
\hline Restructured family & 1,549 & 1,551 & 1,436 \\
\hline Sport & & 0,698 & 0,724 \\
\hline Gender & & & 0,678 \\
\hline Financial background & & & 0,767 \\
\hline Type of settlement & & & 0,985 \\
\hline Father's employment & & & 0,829 \\
\hline Mother's employment & & & 0,817 \\
\hline Constant & $0,061 * * *$ & $0,064 * * *$ & $0,121 * * *$ \\
\hline
\end{tabular}

${ }^{*} \mathrm{p}<0,05, * * \mathrm{p}<0,01, * * * \mathrm{p}<0,001$

\section{Hard drugs}

In case of hard drugs it can be said that the effect of family structure is significant as it was said previously too. This result was confirmed by the logistic regression analysis as well as the try-out rate was much higher among adolescents from single-parent families $(p=0,035)$. Nonetheless, neither sport nor the involved socio-demographical factors have a significant effect on the try-out of hard drugs. The results of the logistic regression analysis can be regarded in the following table. 
Table 6: The results of logistic regression analysis on the try-out of light drugs. (Source: FASCES $2015(N=614))$

\begin{tabular}{|l|r|r|r|}
\cline { 2 - 4 } \multicolumn{1}{c|}{} & Model 1 (ExpB) & Model 2 (ExpB) & \multicolumn{1}{c|}{ Model 3 (ExpB) } \\
\hline Single parent family & $3,478^{*}$ & $3,421^{*}$ & $3,374^{*}$ \\
\hline Restructured family & 1,455 & 1,456 & 1,328 \\
\hline Sport & & 0,739 & 0,808 \\
\hline Gender & & & 0,695 \\
\hline Financial background & & & 0,544 \\
\hline Type of settlement & & & 1,116 \\
\hline Father's employment & & & 0,774 \\
\hline Mother's employment & & & 0,563 \\
\hline Constant & $0,025^{* * *}$ & $0,026^{* * *}$ & $0,077^{* * *}$ \\
\hline
\end{tabular}

${ }^{*} \mathrm{p}<0,05, * * \mathrm{p}<0,01, * * * \mathrm{p}<0,001$

\section{SUMMARY}

In case of the different kind of health-damaging behaviours it can be said according to the logistic regression analysis that sport on itself does not influence significantly the try-outs however its protective role appears as a tendency. Furthermore, family structure on itself is not a significantly influential factor except the try-out of hard drug as in this case a significant difference can be seen because the prevalence of trying out hard drug is significantly higher among children from single-parent families. The values of children from single-parent families and restructured families are worse in comparison with their peers living in traditional families which result shows the importance of the stability and holding force of the family well. Furthermore, it is important to remark the difficulties of restructured families. Although, in this case there are two parents and the financial and emotional support comes from two sides, the presence of health-risk behaviours is higher as the change of the original family model means a serious stress source for the child.

The effect of the societal factors could be detected; the differences in health-risk behaviour according to the family structure could be seen by the involvement of these demographical variables in many cases as it is known that these factors are not independent from each other (e. g. the socio-economic status of families with a structural crisis is worse). These factors are subjective financial status, gender, type of settlement and the employment status of the father.

The results draw the attention to the effect of the structural crisis of the family and to the importance of the role of sport. The role of school is important in the treatment of the problems caused by a divorce (or other crisis) where the adolescent spends large part of its day. Intervention is necessary when deviant behaviour (health-damaging or other behavioural disorder) can be experienced by the adolescent. It is the pedagogues' (firstly the class teacher's) challenge to percept the problem, to keep contact with the parent(s), to turn empathetically to the adolescent and to ask the support of the specialist (e. g. school psychologist) if it is necessary. However, beside the intervention the role of prevention is big too with which the prevalence of risky behaviours can be retreated.

\section{REFERENCES}

Barrett, A. E.\& Turner, J. (2006). Family structure and substance use problems in adolescence and early adulthood: examining explanations for the raltionship. Addiction, 101,109-120. 
Bonnel, C., Allen, E. \& Strange, V. (2006): Influence of family type and parenting behaviours on teenage sexual behaviour and conceptions. (Web: http://jech.bmj.com/) 60,502-506.

Bramlett, M. D. \& Blumsberg, S. J. (2007): Family structure and children's physical and mental health. Health Affairs, 26 (2). 549-558.

Brassai, L. (2010): Válasz a kockázati társadalomra: az élet értelmességébe vetett hit. T3 Kiadó, Sepsziszentgyörgy.

Brassai, L. \& Pikó, B. (2005): Szerhasználat és családi tényezők viszonya középiskolásoknál. Addictologica Hungarica, 4 (1),7-29.

Burke, V., Milligan, R.A.K., Beilin, L.J., Dunbar, D., Spencer, M., Balde, E. \& Gracey, M.P. (1997): Clustering of health-related behaviors among 18-year-old Australians. Preventive Medicine, 26, 724-733.

Compan, E., Moreno, J. \& Ruiz, M. T. (2002): Doing things together: adolescents health and family rituals. (Download: 2016.02.01.). (Web: http://jech.bmj.com/) 56, 89-94.

Conner, M. (2005): Health behaviours. (Download: 2016.02.01.). (Web: http://userpage.fuberlin.de/ schuez/folien/conner2002.pdf).

Csizmadia P.\& Várnai D. (2003): Dohányzás és alkoholfogyasztás. In Aszmann A. (szerk.): HBSC Iskoláskorú gyermekek egészségmagatartása. Országos Gyermekegészségügyi Intézet, Budapest, 49-60.

ELEF (2014): Európai lakossági felmérés, 2014. Statisztikai tükör 2015/29,1-9.

Faurie, C., Pontier, D.\& Raymond, M. (2004) Student athletes claim to have more sexual partners than other students. Evolution and Human Behavior, 25, 1-8.

Ford J. A. (2009): Nonmedical prescription drug use among adolescents: The infl uence of bonds to family and school. Youth \& Society, 40, 336-352.

Goldberg, J. H., Halpern-Felsher, B. L. \& Millstein, S. G. (2002): Beyond invulnerability: The importance of benefits in adolescents' decision $\mathrm{t}$ odrink alcohol. Developmental Psychology, 6, 415-428.

Griesbach, D., Amos, A. \& Currie, C. (2003): Adolescent smoking and family structure in Europe. Social Science and Medicine 56,41-52.

Hair, E. C., Park, M. J. \& Ling, T. J. (2009): Risky behaviors in late adolascence: cooccurence, predictors and concesquences. Journal of Adolescence Health, 45, 253-261.

Hallal, P.C., Andersen, L.B., Bull, F.C., Guthold, R., Haskell, W. \& Ekelund, U.(2012): Global physical activity levels: surveillance progress, pitfalls, and prospects. Lancet, 380, 247-257.

Hildebrand, K.M., Johnson, D.J.\& Bogle, K. (2001) Comparison of patterns of tobacco use between high school and college athletes and non-athletes. American Journal of Health Education, 32, 75-80.

Järvinen, M. \& Østergard, J. (2009). Governing adolescent drinking. Youth \& Society, 40 (3), 377-402.

Kopp M.\& Skrabski Á. (2001). Magatartás és család. Magyar Bioetikai Szemle, 7 (4), 1-25.

Kovács E. \& Pikó B. (2009): A család egészségvédő hatása serdülők körében. Mentálhigiéné és Pszichoszomatika, 10 (4),223.237.

Kovács K. (2014). Kapocs,2, 2-13. (Download: 2016.02.01.). (Web: http://ncsszi.hu/download.php?file_id=1528).

Kovács K., Kovács K. E. \& Nagy B. E. (2016): Intézményi hatások a hallgatók egészségtudatos magatartásában. In: Pusztai G., Ceglédi T. \& Bocsi V. (szerk.): Érték, amit az intézmény hozzáadott. Közelitések az intézményi hozzájárulás empirikus megragadásához. Nagyvárad-Debrecen: Partium Press, Új Mandátum Könyvkiadó.

Kovács K. \& Perényi Sz. (2014). In: Nagy Á. \& Székely L. (szerk.):Másodkézböl. Magyar Ifjúság 2012.Budapest, Kutatópont, 245-262. (Download: 2016.02.01.). (Web: http://kutatopont.hu/files/2012/02/Magyar_Ifjusag_2012_MASODKEZBOL.pdf). 
Lohaus, A., Vierhaus, M. \& Ball, J. (2009). Parentig styles and healthrelated behaviour in childhood and early adolescence: results of a longitudinal study. The Journal of Early Adolescence, 29,449-475.

McArdle, P., Wiegersma, A., Gilvarry, E. (2002). European adolescent substance use: the roles of family structure, function and gender. Addiction, 97, 329-336.

Németh Á. (2003). Nemi érés és szexuális magatartás. In Aszmann A. (szerk.): HBSC Iskoláskorú gyermekek egészség-magatartása. Országos Gyermekegészségügyi Intézet, Budapest, 77-85.

Németh Á. \& Költő A. (szerk, 2011). Serdülőkorú fiatalok egészsége és életmódja 2010. Budapest, Országos Gyermekegészségügyi Intézet. (Download: 2016.02.01.). (Web: http://www.ogyei.hu/anyagok/HBSC_2010.pdf).

Pate, R. R., Heath, G. W., Dowda, M, \& Trost, S. G. (1996). Associatins between physical activity and other health behaviors in a representative sample of US adolescents. American Journal of Public Health, 86,1577-1781.

Pikó B. (2005). Középiskolás fiatalok szabadidő-struktúrája, értékattitűdjei és egészségmagatartása. Szociológiai Szemle, 2, 88-99.

Pluhár Zs., Keresztes N. \& Pikó B. (2004). A rendszeres fizikai aktivitás és pszichoszomatikus tünetek kapcsolata általános iskolások körében. Sportorvosi szemle, 4,285-300.

Poortinga, W. (2006). Social relations or social capital? Individual and community health effects of bonding social capital. Social Science \& Medicine, 63, 255-270.

Rothspan, S. \& Read, S.J. (1996). Present versus time perspective and HIV risk among heterosexual college students. Health Psychology, 15, 131-134.

Sabo, D.F., Miller, K. E., Farell, M. P., Melnick, M. J. \& Barnes, G.M. (1999). High school athletic participation, sexual behavior and adolescent pregnancy: A regional study. Journal of AdolescentHealth, 25, 207-216.

Sebestyén E. (2003). Illegális szerek használata. In Aszmann A. (szerk.): HBSC Iskoláskorú gyermekek egészség-magatartása. Országos Gyermekegészségügyi Intézet, Budapest, 6176.

Steptoe A., Wardle J., Fuller R., Holte, A., Justo, J., Sanderman, R. \& Wichstrøm, L. (1997). Leisure-time physical exercise: prevalence, attitudinal correlates, and behavioral correlates among young Europeans from 21 countries. Preventive Medicine, 26, 845-854.

Susánszky É.\& Szántó Zs. (2002). Az egészségi állapot szempontjából veszélyeztetett fiatalok demográfiai és társadalmi jellemzői. In Szabó A. Bauer B. és Laki L. (szerk.): Ifjúság 2000. Tanulmányok I. Nemzeti Ifjúságkutató Intézet, Budapest, 154-165.

Waldfogel, J., Craigie, T. \& Brooks-Gunn, J. (2010). Fragile families and child well-being. Fall 20 (2),87-112. 


\title{
TEACHERS IN A DISADVANTAGED POSITION ${ }^{3}$
}

Authors:

Adrienn Oravecz

Eszterházy Károly University

Csilla Noémi Borsodi

Eszterházy Károly University

E-mail address of the first author:

ora_adri@msn.com
Lectors:

\author{
Mária Dávid \\ Eszterházy Károly University \\ Magdolna Estefánné Varga \\ Eszterházy Károly University \\ Ferenc Mező \\ Eszterházy Károly University \\ Edina Szabó \\ University of Debrecen
}

Oravecz, Adrienn and Borsodi, Csilla Noémi (2017): Teachers in a disadvantaged position. Különleges Bánásmód, III. évf. 2017/1. szám, 39-50. DOI 10.18458/KB.2017.1.39

\begin{abstract}
The writers of this study will use the expression 'disadvantaged' in a broader sense. The first part of the study deals with teachers and teacher trainees who are in a disadvantaged position because they have got a physical disability. Structured interviews were made with 8 persons. The interviews focused on their educational experiences and also their experiences on the labour market. The key question of the interviews was whether the interviewees had experienced negative discrimination or not. The other part of the study written by Noémi Csilla Borsodi deals with teachers who are in a disadvantaged position because they are working in a vocational school. Many times, a lot of people have written about pedagogical success, about its determination and the grouping of its indicators. First, pedagogical success will be discussed from a different perspective, then the working conditions at a vocational school will be mentioned. Furthermore, the reasons for why the traditional concept cannot be 'substitute' into the 'equation of success' for vocational school. Finally some of good practises will be shown that could help motivating students.
\end{abstract}

Keywords: Teachers with disability, being a vocational school teacher of 'general subject as a 'disadvantaged' position, definitions of pedagogical success, drop-out

Disciplines: pedagogy

\footnotetext{
3 The editorial board does not take any responsibilty for the English of the papers. Indeed, we made some slight changes but wanted to keep the style of the authors.
} 


\section{Absztrakt}

Ebben a tanulmányban a szerzők tágan értelmezik a hátrányos helyzetet. A tanulmány első része olyan tanárokkal és tanárjelöltekkel foglalkozik akik fogyatékosságuk miatt hátrányos helyzetüek. A kutatás során 8 strukturális interjú készült. Az interjúk kulcskérdése az volt, hogy az alanyok részesültek-e negatív diszkriminációban az oktatás és a munka világában. A tanulmány második része a szakiskolai tanárokkal foglalkozik. A pedagógiai siker értelmezése új nézőpontból lesz bemutatva, továbbá annak okait tárgyalja a szerző, hogy a hagyományos siker értelmezés miért nem illik a szakiskolai környezetbe. Végül néhány a szakiskolában használt jó gyakorlat kerül bemutatásra.

Kulcsszavak: Fogyatékkal élő tanárok, Szakiskolai közismereti tanárok, Pedagógiai siker, Kiégés

Diszciplína: pedagógia

\section{PART: TEACHERS WITH DISABILITIES}

\section{Introduction}

Social inclusion of people with disabilities is a re-current topic especially since Hungary belongs to the European Union. Several research were made about attitudes towards people with disabilities including the research titled Opportunities for social integration among young adults living with disabilities in contemporary Hungary in this project the goal was to map the status and positions of youngsters and young adults in higher education, as well as the current weight, prospects, and long-term participation in academic life and the labour market of the target group's representatives. The project's researchers also wanted to find out their motivation why they wanted to take part in higher education. The first major part of the research focused on the actual knowledge of students in the institutions of higher education about disabilities in general as well as opportunities of social integration of people living with disabilities and what can be done to help them. The second part dealt with bodies and organizations in the labour market who can help people with disabilities to find job or create working conditions which are suitable for their special needs (Laki, 2010). Another interesting scientific research examined parents' attitude towards children with cerebral palsy. According to the writer's opinion parents are the most important factors in inclusive education (Zsebe, 2013). The third article titled as Integration Experiences of The Petö Institute which Operates in Segregation. In the article they followed their students' integration into normal basic, secondary and higher education from 2000 until 2010. The results were very positive. (Feketéné and Pásztorné, 2010).

What makes this research unique is that it directly address to people who lives with disabilities. Former students of The Petö Institute were involved into the research who works as a teacher but in order to find more representatives of the target population the snowball sampling was used. The qualitative research method more specifically structured interviews had been applied for data collection.

\section{Two different understanding of disability and the history of qualification for disabled people}

According to the first understanding people with disabilities negatively differ physically or mentally from their able-bodied peers. These differences can be measured by medical or psychological tests. The other understanding focuses on the organisational and institutional tasks which makes inclusive education possible. (Bánfalvy, 2008.) After the two different approach to disability the writer will talk about briefly the history of qualification for people 
with disabilities. Until the $19^{\text {th }}$ century the need of qualification for disabled persons had not been appeared. It was after the French Revolution when they were registered and slowly but surely special institutions were opened. In the developed countries including Hungary segregated schools started to operate, for example the school for blinds. In the $20^{\text {th }}$ century the services of special education became more and more developed. People with disabilities received treatment and rehabilitation which was best suitable for the severity of their disability. The present trend in the European Educational Policy wants to foster social integration of people with disabilities through education. The differences can be found how different European countries define and think about inclusive education. The integration movement began in the Scandinavian region with the Principle of Normalization. In Denmark in 1969 it was defined that if not necessary children with disabilities should learn with their able-bodied peers. Then in 1975 in the USA it was enacted that the environmental barriers must be reduced and they had to learn in the mainstream education and not in segregation. This law also supported parents' rights and the introduction of various pedagogical examination and tests including annual development report about their health condition. At the end of the century three tendencies were general in the practice of integrated education. In the first tendency integration exist as an exclusive solution, for instance in Italy. The Italian law was enacted in 1977. The second type of tendency the permissive liberalism was typical of England. The English Educational Law in 1981 became known as 'Special Needs in Education' later this was further modified in 1993. It was defined in this law in order to find the best education for the children must gather as many information as possible from different specialists. Proper control and occasions for regular consultation provided by The School of Special Education. The task of the segregated school was to prepare the children for inclusive and mainstream education both physically and psychically. The third tendency was called regulation based on practise and this was usual in Germany. The parents took part very actively and fight for their children rights. The Movements of The Parents quickly spread through the country and had a representation in each region. For example, the Integration Law of Hessen Region (1992) emphasized that basic education must provide inclusive education if the parents claimed for it. The third paragraph of the law dealt with the supportive and consultative role of primary schools. Wrote about two different learning management. The first type of learning management when the special education teacher worked with students during the lesson. The second type when the primary school teacher did the process of development herself based on the recommendation of the special education teacher (Deák, 2007).

\section{The Situation and the Process of Integration in Hungary}

The first law in connection with integration was written into The Constitution of The Hungarian Republic in 1949. In 1998 The Hungarian Republic joined to The New York Agreement which defined the rights of the children. The next important law appeared in 1993. This educational law created the theoretically background for integration. The next important law was introduced in 1998. XXVI. Law declared fair treatment and equal rights for people with disabilities (Vargáné Mező, 2006). In the last 30 years children with special educational needs had been played a very significant role in the educational policy of OECD. In 2006 The UN resolution clearly emphasized active social presence of people with disabilities and called the attention to the importance of information and data collection. The Pedagogical Professional Group of Children with Special Needs was founded in 2007 (Csányi,2008). Due to the favourable international and national terms and laws more and more people with disabilities can participate in the normal education. The 1. table shows the number of students who took part in integrated education from nursery school till secondary school. 
1.table: The number of students who took part in integrated education (resource: Csányi, 2008.)

\begin{tabular}{|l|l|l|}
\hline School years & Frequency(student) & Relative frequency* \\
\hline $2002 / 2003$ & 18165 & $28,3 \%$ \\
\hline $2003 / 2004$ & 24993 & $36 \%$ \\
\hline $2006 / 2007$ & 41978 & $51,4 \%$ \\
\hline \multicolumn{2}{|c|}{$* 100 \%=$ total number of students of a school year }
\end{tabular}

Similar survey was done by the after care service of the Petö Institute in $2008-2009.55 \%$ of the former students took part in integrated education. 14\% was nursery school students $21 \%$ was primary school students $12 \%$ was secondary school students $6 \%$ of them took part in higher education (Feketéné and Pásztorné, 2010). Though the results are very positive year by year but in the real daily education rigid integration is still in practise due to the lack of personal and technical terms.

\section{The research sample}

8 structured interviews were made with disabled teachers. The sample involved four men and four women. The distribution of their age were the following: three of them were between 20-30 years old, four of them were 30-40 years old and, only one person was between 50-60 years old. The great majority was born with cerebral palsy. Two people from the eight was born with visually impairment. Only one person was born with auditory impairment.

In the interviews the writer was eager to know if they took part in integrated education or not. The great majority took part in integrated education. The results correlated with the statistics mentioned above. Only two person took part in segregated education during their nursery school years. Only one of them learnt in segregation during his secondary school years. The majority said that he/ she was fairly treated and accepted by his/her classmates. It was said by H. B that she could make very close friendships during her secondary school years and up to the present day she keeps in touch with them.

The minority for example H. R. said she studied at The Institution for Blinds from the $1^{\text {st }}$ grade until $4^{\text {th }}$ grade, then she was sent to a normal primary school where she was looked down on by the others therefore she had to change school. She said the following: "While I was studying in The Institution for Blinds I was in a protective environment but in the normal primary school I was the black sheep of the class. I was unprotected and I had to find my own position in the race condition and try to keep up with the others.” M. G. also said his primary school years were very difficult. He was taunting constantly, but soon he learnt not to pay attention to these mockery words.

In the second part of the interviews examined the reasons for their career choice. Two person from the sample said he /she wanted to be a teacher because his/ her former teacher. G. J. said that he had a very good history teacher and he was greatly influenced by her. H. B. also mentioned her history teacher as a great model. After her first history class she went home and said the following to her parents: "Mummy, Daddy I want to be an archaeologist when I grow up. Later the picture became clear and I chose the faculty of history at university but I still have very vivid memories of my history teacher." Personal interest was the other reason. Gy. D. said he enjoyed drawing since his childhood. He went to private drawing classes to develop his talent. As an adult he wanted to be an artist, but soon he recognised that he will not earn enough money for living so he decided to get a qualification as a drawing teacher. $\mathrm{K}$. B. told she could not decide between psychology and teaching Hungarian as foreign language as result she is now doing both academic specialization, but she added she was always interested in teaching Hungarian language for not a native speaker because it is more challenging. Two people said their disability determined their career orientation. All of them 
said that their teaching practicum at the university was a positive experience. K. B. mentioned that the students were kind and helpful. Her blindness was not seen as a problem, rather the students enjoyed that they were allowed to shout instead of rising their hands up during the lesson. After they had completed their teaching practicum successfully the majority felt that it was the best decision to take when they applied for teacher training.

The third part focused on their experiences on the labour market. The great majority said they were not discriminated because of their disability. Moreover, two of them got a job soon after graduation due to his acquaintanceship. The minority of the research rather represents the current situation in Hungary. M. G. said when he applied for a job he often experienced negative discrimination for example the employer shut the door in front of him or his job application was refused due to his disability. R. G. said it took more than two years to find his present job. Before that he was employed by a charity for blind people. He had been fired during his convalescence after his leg operation. He had hard times because he had to cope with the physical pain but also the psychical pain of being unemployed. His negative experiences continued when he worked as a hotel receptionist. The hotel employed people with disabilities. As R. G. said they did it because they wanted to get a huge amount of financial support from the Hungarian State. Money talked instead of good intention. The author hopes that the reader will be deep in though after reading these shocking examples.

\section{Final thoughts and conclusion}

As the author experienced for people with disabilities the success has a greater importance in life because they have to demonstrate day after day that they are as valuable as able-bodied people. Education is one of the fields in which they can have a real sense of achievement. As the disabled teachers noted that for them pedagogical success means when they see their students are more tolerant and helpful with people who are in the disadvantaged position. The disabled teachers mentioned that they find it important to enhance the students' emphatic skills during form class activities. The writer strongly believes they have a significant role in the formation of mind and attitudes of the next generation. Thanks to the pedagogical work of teachers with disabilities maybe a new and more tolerant young generation will grow up and social exclusion will not be as harsh as today.

\section{PART: SITUATION OF VOCATIONAL TEACHERS}

\section{The pedagogical success in general}

Although the definition of success is relative, yet to be able to write about its implications at a vocational training school, it is essential to broadly outline what a teacher's success means 'in general'. Beatrix Füzi identified three indicators: good results by the students, popularity among students, and the good general mood of the teacher (Füzi, 2007; 2012; 2013). According to another research, the productivity of an educator coincides with his or her 'popularity', and it mostly depends on how much he/she can win the student's sympathy. (Suplicz, 2011). These works emphasize that although the teacher's methods are secondary, and are hard to correct them afterwards, once the students 'have categorized' them (Füzi 2013), a sort of 'ranking', an order of popularity can still be established among them. The teachers and teacher candidates like the student presentations as a form of work. This is the most effective way for them to help the realization of student performance, the development of communication skills, and demonstrably the students also like this interactive form of performance, as they also gladly act as 'junior teachers' during group work. (Füzi, 2012; Mrs. Kovács Duró, 2004; K. Nagy, 2006) It is proven to be the biggest disadvantage, if the teacher's personality is not what's desirable. (This picture is toned further by the fact that getting to know someone is a fairly complex process, and the students might only see the 
current general mood of the teacher role personality.) Another important factor is the level of appreciation for the specific teacher's subject among the colleagues and their students. The good teachers like their subjects and consider them important, whereas the bad teachers don't feel that way as much. It is certain in any case that the series of failures sooner or later reproduce themselves, the teacher will work without motivation, thus he/she won't be able to motivate the students either (Suplicz, 2011).

\section{The society of vocational school students - the risks of failures at school}

Many researchers consider the vocational school to be the 'home' of failures, where the students who attend experienced failures at their previous schools (Bánfalvy, 2001), or they are the children of poor parents with low level of education (Mogyorósi, 2009). A vocational school is the scene of student heterogeneity. These learning communities are 'considered to be a collecting class' by some teachers, who also believe that their development is didactically unachievable. This is primarily characteristic to the older generations, but the younger ones do not yet possess the necessary diagnostic skills, it is harder for them to determine 'at a glance' who those students are that 'they have to watch closely' (Óhidy, 2013).

On heterogeneity we do not just mean the diversity with respect to abilities, but also with respect to age groups, namely that here the 16 year old youngsters go to the same class as the 24 year old full-time students. Many students enter the school with a secondary school leaving examination certificate or after finishing the 10th grade, as an adult student for whom compulsory schooling doesn't apply. In fact many of them 'end up' at this 'less prestigious' school - not offering a secondary school leaving examination certificate - because of their relative failures, while others having obtained the secondary school leaving examination certificate, but without a qualification, do not feel ready to start a vocational training that requires a secondary school leaving examination, or to enter higher education. They all lived through failures, but as the learning community itself, the failures are also quite heterogeneous. For some failure means the bad grades that they got in their previous schools, while for others it means not passing a class. The main failure for a student and teacher at a vocational school is 'dropping out', whatever we mean by that. The term itself covers a different meaning country by country. In Hungary we don't primarily mean not passing, it rather means that the student is gradually missing school more and more often due to lack of motivation, possibly truancy, or other reasons. In countries, where the expansion of secondary education has not yet happened, e.g. Portugal, neither dropping out nor repeating the school year is a general problem (Szöke, 2009). The OECD statistics examines two kinds of dropping out; one is the number of youngsters aged 16-19 who do not participate either in the education or at the labor market, the other is the ratio of 20-24 year olds, who do not have secondary education. Although in our country the rate of dropping out significantly decreased before the regime change, it showed an increase again after 1995, namely, the assessment carried out among the 18-24 year olds proved that the $12 \%$ of these youngsters don't have any qualification. This problem is also specific to vocational training schools, as in the high schools and vocational secondary schools this issue is only the individual tragedy of a few percent of the students, while in relation to the vocational training schools this is a social phenomenon, since it effects a third of the youngsters (Szőke, 2009). Educating dropouts together with students who have detrimental situations is the main task of a vocational training school. Due to the character of the continuously changing vocational training at these schools, these students can amount for two third of the class (Mogyorósi, 2009). Therefore they have to be considered as a majority, and not as an exclusive educational specimen. The teacher must find a different role as an educator. He or she cannot live the role of the 'lone' 
teacher, but has to become a 'team player'. Not only the teacher has to become able to cooperate with the student community, but with his or her colleagues as well (Nagy, 2009).

\section{An empirical research}

We wanted to see if we can more or less generally state that the sense of success for a teacher working in the vocational training changes in a special direction, and whether we can consider a teacher successful who can merely hope that the students attend her classes, feel themselves comfortable, and appreciate her. Our hypothesis was based - after consulting the literature - on this. We assumed that the general knowledge teachers at the vocational training schools consider motivating the students and preventing them from dropping out as their main success. We thought that the students consider - unlike the teachers - organization less important than the class being entertaining. We hypothesized that the teachers consider the unpredictable student attendance and the heterogeneity to be the most serious problems at the vocational training school. We believed that the vocational training school students attend the classes of those teachers who they like. Dropping out was considered as the common failure of the vocational training teachers, the forewarning signs of which are interpreted as a danger even by the students.

Our goal was to identify the student and teacher signals relevant to the problems that are characteristic to vocational schools. 18 colleagues responded to the questions. Two of them are from Nógrád county, 4 people work in Miskolc, one person is the employee of a vocational training institution in Nyíregyháza, the others all work at schools in Budapest. In terms of their subjects, they 'make up a heterogeneous group'. General knowledge and technical teachers, or learning methodology specialists can all be found among them. The students we questioned are from Miskolc. Because of the unpredictable student attendance and the heterogeneity regarding their abilities, 5 ninth grader, 12 tenth grader, and 14 eleventh grader filled out the questionnaire. The research is by no means representative, however both the teacher and the student responses clearly outline how they conceive their own successes, effectiveness, and the main obstacles to their work. In the next section of our work we present the results of this mini research, before we would outline the results of our inquiry among the students.

\section{Presenting the results of the teacher assessment}

While questioning the colleagues, we learned that most of them identified the lesson planning difficulties caused by external factors as the main problem that are hindering the efficiency of their work. They could evaluate the weight of the individual problems on a scale of 5 (problems with a vision for the area to teach; lesson planning difficulties caused by external factors; problems with methodology; discipline issues). This obstacle related to learning and teaching organization received 4.3 points, which can be viewed as completely evident, a "necessary bad", due to the lack of material assets and the lack of student leaning items, which are natural in vocational training. These difficulties are followed by the methodology obstacles with 4 points, after which the lack of vision for the area to teach is listed with a value that is a mere 9 hundredth smaller. Perhaps the weight of this problem did not appear with such intensity as it had been assumed, because we equally questioned colleagues teaching technical subjects and general subjects, not exclusively the colleagues teaching 'the lacking general knowledge subjects' (natural studies, social studies, communication-Hungarian), who are trying to support and motivate students virtually without any teaching tools, or more precisely, with the teaching tools they had made themselves.

The colleagues who were questioned consider tolerance to be the most essential from the aspect of teacher effectiveness. (On a scale of 5, this factor received 4.72 points, which can be viewed as outstandingly high.) In a very 'tight list', that is with almost identical order of 
importance, this is followed by efficient communication with the students (with a score of 4.58), and empathy (4.54), as well as the commitment to lifelong development (4.58), from which the methodological diversity also isn't far with its 4.5 points.

We were interested to see the consequences of separating the tolerance that is connected to the acceptance of being different from the empathy that is related to a sense of sameness, whether there is a correlation between the two values. The efficient communication with the students based on these is of key importance, as is the cooperation with them (4.45 points). However, for some reason the cooperation with the colleagues does not seem to be of key importance for the colleagues, albeit we assumed that it was fundamental. Another thing that we found strange: the judgment on the sense of humor is rather "medium" (3.2) in the eyes of the teachers.

Among the difficulties specific to vocational training schools, the strong heterogeneity with respect to age and ability (4.5 points) and the unpredictable student attendance (4 points) emerge as the most striking obstacles. We would have also liked to know how well the teachers can judge their own alternative sense of success, but in 5 cases we did not get a response for that part.

From the choices for this question the following dimensions were found: achieving motivation, student development (added pedagogical value), (former is implied by 6 , the latter by 4 responses), providing equal opportunities and substantial implementation of personal example, conveying general literacy and know-how (each in 1 case). If we consider this response to be in the "accomplishing development" category, then we can state that my colleagues bring that to the fore. Furthermore, a response was received that emphasized motivation and cooperation, and one person interpreted the student attending classes as a success. On the basis of all this we can infer that motivation and student development (which cannot be achieved without motivation) are the leading factors that the teacher at a vocational training school pursues. The teachers would like to achieve that these students become more motivated, attend school and thereby develop (in the areas of knowledge, ability, skills, personality, and self-knowledge). In relation to failure we asked multiple choice questions. The colleagues' unambiguous opinion was that dropping out means the real failure (based on 12 responses). 6 people stated that for the teachers a sense of failure can be caused by the students' lack of motivation, 5 thought that this can be caused by not attending classes, and only two of them believed that the students' disorderly conduct, continuous lack of discipline could be a cause. We were surprised that in multiple different groups of questions the response We received stated that the problem with the lack of discipline cannot be considered relevant. Nevertheless, if we think about it, these statements confirm the following: once the vocational school students attend the class, then they like to be there too. If they like the class, they are not disruptive. The trouble is with those who don't even attend. This is what puzzles the teacher, and how he or she could keep those who show up inside, how he or she could be able to influence (through them, establishing intrinsic motivation) the ones not attending. How should he or she give a motivating class (notwithstanding the difficult circumstances due to the unpredictable attendance) the news of which reaches the others and possibly arouse their interest. In this context, it occurred to us that for the conscious realization of all this the colleagues' cooperation is crucial. This view wasn't shared by the interviewees.

In relation to the suppositions about 'good' and 'bad' teachers, we were interested in seeing how the result of our mini research aligns with the information can be read in the literature, and to what extent are the teachers' suppositions confirmed by student opinions. Every single factor that we listed for the "bad teacher", also appeared as a virtue for the 'good teacher'. It was assumed the teachers would think that the students don't (like to) attend the 'bad' teacher's class, therefore it fairly surprised us to see this factor being only the third among the 'bad teacher' criteria, moreover it only received 3.7 points. The 'leading' factor was the black 
pedagogy. Namely, the 'bad' teacher finds pleasure in insulting the students. (4.25 points). The 'good' teacher seems to feel good in the classroom (4.7 points), likes to chat with students (4.6 points), and the methodologically diverse teacher is the one who provides opportunities for student contributions and is not teacher-centered (4.5 points). Basically, the educators said yes to the 'criterion' related to 'being a good teacher' that is also presented in the literature, except for the empathy in this case (3.3 points). This is not surprising: the question was about how the students might conceive the 'good teacher'. Discipline, with 2.9 points, seems to be the least essential 'virtue'. In order to get a clearer picture, we questioned the students as well, in connection with the same categories as for the teachers. We were interested in seeing what they consider the most essential 'virtues' for the teacher. Do these match the teachers' own set of values that are based on their pedagogical experience, specialized knowledge, and professional literacy?

\section{Presenting and evaluating the results of the student responses}

All of our interviewed students are youngsters who attend a vocational training school in Miskolc; they are in the 9th, 10th, and 11th grade. They were randomly chosen, and only those students could be in the sample who came to school at that time. They are members of a heterogeneous student group, many of them struggling with basic reading comprehension and written composition problems, especially among the 9th graders, therefore we did not ask them textual, i.e. open-ended questions in my questionnaire. Subsequently, in the form of individual interviews, then as a group interview, we uncovered the shortcomings among them as well. The students' responses evince the following: although they did not designate planning as the most essential teacher competency, it clearly turned out that they consider those shortcomings to be the most serious that demonstrate lack of planning. The illogical reasoning (3.76 points) and the lack of methodological diversity (also 3.76 points) are these characteristics. These characteristics became 'top three', but none of the teacher deficiencies received a score above 4 , thus even the 'most serious' problems have at most medium significance in the eyes of the students we questioned.

For them, the teacher's 'lack of knowledge' is one of the least significant issues (3.1 points). Only the lack of discipline seems to be less disturbing than this, although in case of a more representative sample of students this difference could have disappeared, or even reversed (3 points). Later on, after filling out the questionnaire, several students orally confirmed their suppositions about the lack of knowledge. Their reaction was something like this: 'There is no such dumb teacher who would not be able to give a class.' For them the 'good teacher' primarily is the one who can clearly explain his or her specialized subject and who helps them understand the relationships between the subjects (4.4 points), as well as the teacher who gives entertaining classes (4.2 points). The students consider those teachers bad who insult their students (4 points). All the other bad teacher characteristics lag behind this one. Perhaps being late (3.8 points) can also be considered noteworthy in their case.

\section{SUMMARY OF OUR RESULTS}

Both the teachers and the vocational school students consider the effectiveness of the teacher-student communication and the underlying organization to be the most essential duty for the teacher. Motivation and working in a good atmosphere have key roles. The students must experience a sense of achievement, and the teacher can make this possible with methodological diversity and logical reasoning. The heterogeneous group composition and the unpredictable student attendance imposes extra planning duties on the teachers, who must fulfill these so that they can lure the students to school. The methodological diversity as the 'underlying factor' of planning has an outstanding role in such institutions as well. Every 
colleague who evaluated the role of planning to at least 4 points, also evaluated the methodological diversity to 4-5 points. The lack of discipline cannot be viewed as a problem, and the students have no desire to be disciplined either. The youngsters who study in a selfregulating way or seeking to do that will attend school even after they reach the age after which schooling is not compulsory. The student who attends school even after reaching this age is motivated. If the student loses motivation, the teacher also feels that to be his or her responsibility and failure, since the loss of motivation and frequent absence is the symptom for the danger of dropping out. All of this is confirmed most definitely by the students' order of values that they create about the 'good teachers'. We seem to discover a sort of relationship between all this, namely the following: it is possible that the 'good teacher' explains his or her specialized subject clearly, and at the same time helps the students understand the relationships between the subject and other subjects, that is he or she gives an interdisciplinary class while considering the students' individual 'paths', he or she is aware of the fact that getting to know the students is the basis for everything. The teacher gives entertaining classes.

During the test of my hypothesis we found that the interviewees consider motivating the students and preventing them from dropping out as the main success. Organization is of key importance for both sides, even if the students consider it as a sort of 'backstage secret'. For the class to be entertaining, to have a logical structure, and the desire of harmonization with other subjects all require planning. The teachers we sought out do indeed consider strong heterogeneity in student composition and the unpredictable student attendance to be the greatest challenges of being in vocational training. The role these play in the planning duties is less relevant. The vocational training school students did not always opine that they do indeed attend the 'good teacher's class'. (Over the course of the interviews they shed light on the'psychology of the absences': there are the 'notorious absentees', and there are those who only seldom miss classes. However, in these cases they 'take the whole day off' and the 'good teacher's' class might also 'become a victim' of the students' 'arbitrary leave of absence'.) The teachers we questioned consider dropping out as a common failure, the forewarning signs of which are interpreted as a danger even by the students, however, they only consider the cooperation between the teachers and students to be important, deeming the teachers' common problem solving irrelevant.

The indicators of success for a teacher who works in vocational training is similar to his or her colleagues' who work at different types of institutions (popularity, teacher's good general mood, student performance), while here student performance means avoiding dropping out, the student's motivation toward getting a profession, and the desire for self-improvement. In this case by 'added pedagogical value' we mean becoming more independent and getting a higher level of educatedness. It could be the topic of further research to see what the reason is for the teachers not considering collaboration with their colleagues as of key importance, and whether this is indeed a 'mass phenomenon'. Let us in the closing section of our study present a few 'good practices' that can help you to 'lure the students to school'.

\section{Some good practices that can help in the motivation of vocational school students}

Initially the author only taught the communication-Hungarian language and literature subject - which was introduced during the 2013-14 school year - in the 9th grade. Her educational activity is characterized by different classes, different demands, and different approaches. At the beginning of this assignment my goal was to develop critical thinking (still is), and to arouse their interest toward my colleague's complex subject named social studies, furthermore to shed light on the fact that there is no truth, merely viewpoints. The path, which is well-tried by now, that lead her here she discovered thanks to an accidental situation. Seh arrived as a substitute. She had just come across a film about Elizabeth Bathory that depicts 
her as a 'blood countess'. There was an opportunity to watch the film, evaluate it according to a list of discussion points, then to implement a reading comprehension practice arguing that the countess was the victim of a kangaroo court. The students were divided by this topic. Later she taught them the techniques of debate and reasoning based on this as well. It served as a starting point for the other contents of the subject, e.g. to introduce the work of Kálmán Mikszáth and the criteria of the folksy style (starting from the novel about Elizabeth Bathory, titled Csejte vára és asszonya [The Lady of Castle Csejte]). This topic had many aspects that we carried forward, e.g. we compared the pact with 'the Devil' made by Goethe's Faust to Elizabeth Bathory's 'bathing in blood'. The people of earlier times did not believe in talent, exceptional gifts, or genetics. Anything that was different from the 'ordinary' they attributed to 'the Devil'. This way of thinking was also tied to the contents of natural studies and social studies. She often does situation exercises with her students, the objective of which can be the practicing of communication styles or the forms of language usage, and the development of problem solving thinking. These games are similar to the board game named 'Beugró', and when she realized this similarity she bought one of these. In addition, she also equipped a Definity game with technical terms for the purpose of practicing foreign words and new concepts. All of these contribute to the good atmosphere of our classes, the students do not distance themselves from frontal work, and more of them like the 'playful' recitations. During grammar classes, to "sweeten up" the assessments she turns to the quizzes at www.kvizpart.hu or www.anyanyelvapolo.hu, or to the previously mentioned Definity game.

\section{REFERENCES}

Bánfalvy, Cs (2001). Szakképzés a szakképzés föáramán kívül. Educatio, 2, 278-294.

Bánfalvy, Cs. (2008). A mai integrációs folyamatok és azok előzményei. In Cs. Bánfalvy (ed.). Az Integrációs Cunami. Tanulmányok a fogyatékos emberek iskolai és társadalmi integrációjáról (Vol. 1. pp.11-44) Budapest. ELTE Eötvös Kiadó

Csányi, Y.(2008). Új utak és törekvések az SNI-tanulók oktatása terén. In Cs. Bánfalvy (ed.), $\mathrm{Az}$ Integrációs Cunami. Tanulmányok a fogyatékos emberek iskolai és társadalmi integrációjáról (Vol. I. pp.65-74) Budapest. ELTE Eötvös Kiadó

Deák, A.(2007). Érvek és ellenérvek mozgássérültek integrált nevelésével kapcsolatban Empirikus vizsgálat Spanyolországban és Magyarországon. Doktori Disszertáció. Budapest. Eötvös Lóránt Tudományegyetem

Feketéné, Szabó É. és Pásztorné, Tass I. (2010). Integráció- Egy szegregáltan működő intézmény tapasztalatai. Budapesti Nevelö, 2, 23-38.

Füzi, B. (2007) A sikeres pedagógiai munka néhány összetevője. Egy kísérlet tanulságai. Pedagógusképzés, 3, 9-30.

Füzi, B. (2012) A tanári munka sikeressége a pedagógiai attitűdök, a tanár-diák viszony és az iskolai élmények összefüggésrendszerében. Doktori Disszertáció (kézirat) Budapest. Eötvös Lóránt Tudományegyetem

Füzi, B. (2013) Az érzelmi-kapcsolati elemek tanítási módszerek hatékonyságára gyakorolt hatásai. In. Tamás Kozma - László Perjés (ed.). Új kutatások a neveléstudományokban. A munka és nevelés világa a tudományban. (Vol. 2. pp. 153-169) Budapest. MTA Pedagógiai Tudományos Bizottság, ELTE Eötvös Kiadó

K. Nagy, E. (2005) A társas interakció mint tudásgyarapító tényező a heterogén osztályokban. Iskolakultúra, 5, 16-25.

Kovácsné Duró A. (2004) Tanár szakos egyetemi hallgatók értékelési tudása és kompetenciái. Magyar Pedagógia, 2, 203-224.

Laki, I.(2010). Fogyatékossággal élő fiatal felnőttek társadalmi integrálódásának esélyei és lehetőségei a mai Magyarországon. Budapest. L’Harmattan Kiadó 
Mogyorósi Zs.(2009) A hátrányos helyzet öröksége. In. Mária Nagy (ed.). Tanulmányok a neveléstudomány köréből. A közoktatás méltányossági problémái és a tanárképzés. (Vol. 1, pp. 7-39.) Eger. EKF Líceum Kiadó

Óhidy, A. (2013). Heterogenitás, tanári kompetencia, tanárképzés. A heterogenitás pedagógiájára való felkészítés a német tanárképzésben. In. Tamás Kozma - László Perjés (ed.). Új kutatások a neveléstudományokban. A munka és nevelés világa a tudományban. (Vol. 7, pp. 475-490) Budapest. MTA Pedagógiai Tudományos Bizottság, ELTE Eötvös Kiadó

Suplicz, S. (2011) A tanárok pszichológiai jellemzői diákszemmel. Doktori Disszertáció (kézirat), Debrecen. Debreceni Egyetem

Szőke, K. (2009). A lemorzsolódás problémája. In. Mária Nagy (ed.). Tanulmányok a neveléstudomány köréből. A közoktatás méltányossági problémái és a tanárképzés. (Vol. 1. pp. 41-58.) EKF Líceum Kiadó, Eger

Vargáné, Mező L.(2006).(Download: 2016. 07.06.)

(Web: http.//rs1.szif.hu/ nyeki/okt/jog_hatter.pdf).

Zsebe, A.(2013). Mozgássérült gyerekek inkluzív nevelése. In I. Bábosik (ed.), Az iskola optimalizálásának lehetőségei.(Vol.3, pp. 139-152.) Budapest. Eötvös József Könyvkiadó. 


\title{
THE BODY: INSIDE AND OUTSIDE ${ }^{4}$
}

Szerzők:

Emília Lívják

Eszterházy Károly University Comenius Campus

E-mail address of the first author:

livjak.emilia@uni-eszterhazy.hu
Lektorok:

\author{
Magdolna Estefánné Varga \\ Eszterházy Károly University \\ Katalin Kissné Gombos \\ Eszterházy Károly University \\ Ferenc Mező \\ Eszterházy Károly University \\ Edina Szabó \\ University of Debrecen
}

Emília Lívják (2017): The body: inside and outside. Különleges Bánásmód, III. évf. 2017/1. szám, 51-57. DOI 10.18458/KB.2017.1.51

\begin{abstract}
The reality of the child's life is through bodily experience. The early-motion reflex correction program builds on body experiences. It is very important for the body to move consciously, feelings, body experiences and feedback are important. According to Fodorné, it is not generally necessary to provide an ingenious environment, but to develop sound stimulation programs during motion development. Progress should be considered in a dynamic system approach. The system is part of the whole personality of the child, physical and mental abilities, personal and physical environments, etc. The absence, multitude, excess, and unpredictable imbalance of the stimulus can have consequences. The theories of phenomenological thinkers, neuroscience, INPP movement and psychology research are analyzed.
\end{abstract}

Keywords: Body interpretation, body experience, nervous system, INPP

Disciplines: physical education, pedagogy, phylosophy

\section{Absztrakt}

A gyermek életében testtapasztalat útján épül föl a valóság. A korai jelekre épülő reflexkorrekciós mozgásfejlesztő program a testtapasztalatokra épít. Nagyon fontos a test tudatos mozgatása, fontosak az érzések, testtapasztalatok, a visszajelzések. Fodorné szerint nem általában kell ingergazdag környezetet biztosítani, hanem rendezett ingerprogramok kidolgozása szükséges a mozgásfejlődés során. A fejlődést dinamikus rendszerszemléletben

\footnotetext{
${ }^{4}$ The editorial board does not take any responsibilty for the English of the papers. Indeed, we made some slight changes but wanted to keep the style of the authors.
} 
kell vizsgálnunk. A rendszer része a gyermek teljes személyisége, fizikai, és mentális adottsága, személyes és tárgyi környezete, stb... Az ingerek hiánya, sokasága, túlzása, egyszóval kiszámíthatatlan egyensúlytalansága, következményekkel járhat. A fenomenológiai gondolkodók elméletei, az idegtudomány, az INPP mozgásprogram és a pszichológia kutatásainak összefüggéseit elemzi az írás.

Kulcsszavak: testértelmezés, testtapasztalat, idegrendszer, INPP

Diszciplína: testnevelés, pedagógia, filozófia

The thinking about the body presumes that we make questions to understand it. It is our natural wish to discover the world and the sport expert's instinct desire is to know the human body. What is my body like? How do I see it? How do I perceive it? Where is my body in relation to other objects? Where is my body in relation to the perceived reality? Here we think mainly about the physical reality of the body but this philosophically interpretable phenomenon had multiple ways of interpretations by various philosophers throughout history.

The philosphical thinking about the human body had been exhaustively influenced by two dualistic theories: platonism and cartesianism whose traces can be found even in our presentday thinking. The modern interpretation of the body is still vastly determined by dualisms where the body and the soul, the body and the consciousness, the body and the spirit were in conflict with each other. The effect of these dualisms can be still felt in our everyday lives, science and the consumer culture as well. On the other hand the 20th-century thinkers stepped beyond the dualistic thinkers and phenomenology entered into history with a new way of interpretation.

\section{PHILOSOPHICAL INTERPRETATION OF THE BODY}

In the interpretation of the body from among the ancient thinkers Platon considered the terrestrial order, the nature, the human body and the substance itself as lawless and morally deficient whose raison d'etre is just to be transformed by the order of intelligence. Platon believed that there are two ways of existence, a visible and an invisible one. The invisible is always the same but the visible never. The body is in relationship with the visible while the soul is invisible. The soul is similar to be divine while the body tends to be mortal. The divine is set to rule, lead, the immortal is subject to subordination and servitude. Therefore those who had been focusing on carnal pleasures throughout their lives, cannot break away from their bodies as they are permeated by corporeality and their souls will be housed by races like ass or other savage animals. These ideas constitute the base not only of life-denying thinkingswhere Earth and secular things are despised but that of Christianity as well. The fallible and sinful nature can be redeemed by the divine Logos (later the divine science).

The tamed ,good" and the „bad"ancient nature shall be confronted with each other where the battle of the body and soulwill be fought to save the immortality of the soul from the fallibility of the body. The split of the body from the soul, the rise of the spirit's importance and the valuelessness

of the body greatly contributed to the theory creation by later thinkers of history.

Renaissance and the early New Age was a very colourful period of time when the birth of modern natural sciences coincided with the wildest cases of witch burning. 17th century philosophers wanted to create some order in the spritual chaos of the age by trying to find answers of the way how you can get knowledge in the best and most prolific manner. Two 
answers were found, the rational and the empirical. Both negated the dogmatic thinking and wanted to establish a new base for cognition.

Europe was the main soil of rationalism with Descartes as one of its greatest figures who was looking for incontestable truths which new-age sciences could be relied on. According to rationalism the principles of cognition are to be acquired by the individual's own intellect. To be able to experience the world around us is determined by the laws of rationality and intellect. All knowledge gained is based on the clear function of our own mind.

This tradition determines the cognition-related independence and freedom of the individual, the free use of the intellect while making no discount to experiences at the same time. Descartes found the ultimate truth in the controllable and incontestably evident consciousness on which the new age sciences could be built.

This is the idea which simultaneously established the base for the dualism and individualism of the modernman. According to Descartes existing things can be divided into two, the conscious thing - res cogitans and the extensive thing - res extensa. All extensive things are mere subject of my thinking and nothing else, consequently my thinking cannot be part of the extensive thing but in fact it stays out of everything. Me as an intellectual being cannot be part of the nature just examine it as an exteriority. My body is also an exteriority belonging to the res extensa zone and obeying the laws of physics just like any other object in the outside world.

In Descartes' theory my corporal feelings do not belong to me as an intellectual person, they are just subjects of my thinking. However his theory formed the notion of the human body as a physical thing which is not myself as subject of outer perception and functioning like a lifeless mechanism. Even today this is still the body notion of anatomy, general medicine and majority of sport sciences.

The cartesian dualism and several ancient philosophers considered the body as rest of the consciousness. The first philosophers who interpreted the body in its trues reality appeared only at the beginning of the 19th century.

According to Nietzsche our rational world is pure reaction. The first major source of Western culture, the world of Platonic ideas which do not consider the body original but just a reaction. He is the first to deal with body experience. This very same reactionism comes forward in Christianity and modern sciences as well. The scientist is interested not in life itself but an abstraction of it. Nietzsche thought we must use hammer to make philosophy by destroying the body-soul dualism ruling in Western culture.He thought that man is not a separate body and soul but a body in its entirety. „I am body and soul.” Body is big intellect, diversity, war and peace together, a pen and a shepherd. My blood! Your tiny little intellect is your body's tool which you call ,mind”, little tool and toy of your big intellect". (Nietzsche 1908, 41)

The experience, the vivid, sensual desires and energies of the body come from the deepest abyss of our existence with full of intellect. We can become ourselves only if we live through our corporal reality.

„Behind your thoughts and emotions, my blood, stands a mighty ruler, an unknown sage whose name is ,self". He lives in your body, he is your body. There are more intellect in your body than your best truth." (Nietzsche 1908, 42) We are not the same either with our consciousness or soul. Consciousness is an oft shadow, servant of huge emotions, desires, knowledge of the body. A wise man always relies on his physical senses, a bigger wisdom.

Parallel with this, Freud's theory of psycho-analysis is also published which marks the growing importance of the body as a notion, its experience and rise of its understanding.

Opposite to the Western tradition of Platonism and cartesianism Freud claimed that not only the body but also the soul can be divided since as field of inherent conflicts much more power 
is working there. Instinct is the body's check-in to the soul! It does not handle the body as an outside object but as an inner experience.

Its duality stands in the fact that by maintaining the natural scientific, mechanical model and body interpretation, at the same time it gives scientific frame to the most subjective corporal experiences. Although he considers ,self” of carnal origin, in his theory the body does not appear directly but rather as symbolic representation. In the new-age philosophy instead of soul we meet the notion of sense. Depending on which level the specific spiritual process can be found in the course of apperception Freud discerns three qualities, the conscious, preconscious and unconscious ones.

Phenomenology is the science of phenomena. According to Husserl the subjective experience is the basis of interpretation of the phenomena and starting point of all our explanations.

In phenomenology subjective / own experience keeps receiving more emphasis but simultaneously objective experience also turns up. According to this theory the body can be the most subjective and the most objective at the same time. The body and its experience is the very first object in human life. Body is the most inherent subject-object relationship. Already our earliest experiences we live both in a subjective and objective way. Body can be the most alien and most subjective at the same time. This double experience is the link that connects a new-born baby with the outside world and all inter-subjective experiences come after this first in the maternal then in the ever-expanding general environment.

Body is the carrier of all experienced feelings and realities. The reality of the body is experienced through motion. The motion of my body is the world where I have already been and where I want to go. The motion of the body has a norm-creating function as it leads to the birth of subjective samples, quantitative and qualitative standards.

The building power of reality is evolved through body experience. The reflex excitation based on early signs and the reflex correctional motion development program both relies on the body experience. The deliberate motion of the body, the feelings, the body experiences and the feedbacks are of utmost importance. I think that the theories of the phenomenological thinkers, the neuroscience and the physhological researches can be connected just as Lajos Horváth says ,we are facing a hybrid discourse”. Apart from the dynamic system approach Lajos Horváth accentuate the role of neurophenomenology mainly epokhé and corporal experience (proprioception, kinesthesis)

in Husserl's philosophy. „The phenomenal field and the intentional action cannot be reduced simply to specific brain areas but these peculiarities are manifested in the intertwining connection of body regulation, sensomotoric linkage and intersubjective interaction." (Lajos Horváth 2011, 1306-1315) To properly understand this phrase we need to clarify the single notions.

The phenomenal field in Rogers' interpretation is man's ever-changing, individual world of experiences. This field is not only experienced but evaluated from the own point of view and classified as a positive or negative print. These experiences are not always conscious ones. As per Lajos Horváth's interpretation of the previous phrase, the intentional action is not controlled by a specific brain area but through the synchronicity of the perceptive and locomotive organs a mutually conscious interaction is generated to perform it. The individual experiences, the coordination of the body, the sensomotoric prints can be interpreted only in the relationship of a person, an object or a situation. The interpretation of this dynamic, momentary condition makes possible a new way of body interpretation.

In the first motions, displacements, breathings, reactions we can see the game of discovery, both the visible and the invisible one. „In the world of people and the relationships with others only through perceptions and acts but it does form a perpendicular direction compared to the time-space multitude of actualities". (Maurice Merleau-Ponty, 2007, 162) Through 
perceptions the young child first reacts instinctively through reflexes then starts to walk the bumpy road of motion development assisted by his own reflex responses.

Since - in Merleau-Ponty's words - the child cannot be uprooted from my existence to the Other and the intersubjective interactions, the environment cannot be locked out during evolution.Evolution should be examined through a dynamic system approach. The child's entire personality, physical and mental aptitude, personal and material environment are all part of the whole system. The absence, multitude, exaggeration of stimuli namely the unpredictable imbalance of it may lead to consequences. The right stimuli of the environment around us play a major role in the child's development but not the excess or insufficience of it. In this sense the dynamic balance both of the child and the environment (family, friends, toys, media, sounds etc.) are of huge importance in the first period of life. The reactions given to the first stimuli are primitive reflex responses which are not conscious acts yet but the postural reflexes and the conscious motion based on more and more motion experiences will later be built on them. Examining the evolution of reflexes paediatrician Domokos Boda extricates the following phases of development: 1. Primitive reflexes, 2. Primitive motion reactions, 3. Postural reflexes. The very first reflex motion might seem even strange for the child but at the same time this is the first subjective phenomenon and „own” body experience.

Going through the context of Merleau-Ponty's observations we might be pondering ,when we declare that the other is not else than the unknown origin of my seen-self. Here however we should add that the other can be the source of my seen-self only because I see that he/she is looking at me and he/she can look at me - the invisible - only because we belong to the same system of existence, we are phases of the same matrix, reckon with the same world, rise from the same Existence." (Maurice Merleau-Ponty 2007, 99). We must attribute major importance to Existence since the conception of life!

From the point of view of the development of the nervous system we must presume that the environment, perception, sensation, touch as most essential forms of cognition of the world around us, the self-world and the Existence are decisive in every single moment.

Since the nervous system develops according to the stimuli and the responses to them, the motion progress of a new-born baby is of important significance. „The nervous system is not just an input-output switch but a purport-producing system.” (Lajos Horváth 2011, 1306-1315 ) If we examine the nervous system phenomenologically which is the ,purport-producing system" according to Lajos Horváth, then the nervous system is one of phenomenology's foundation stones from the point of view of body interpretation. Motion progress can be called the first form of cognition. A game between the baby and the environment, the environment and the baby, the baby and the baby's inner world. We might recall the picture where the child contemplates into the endless distance radiating calmness and complacency. Can we presume that this is also a game with self or something? Can we say that the child is looking to nowhere but does nowhere really exist? Or we can surmise that something really happens in and around the child. In this hyper-sensitive age any deficit, deficiency, stress might be enduring for the child. In Domokos Boda's mind the primitive reflexes and reactions in the neonatal and infant age can be triggered age-relatedly during the normal process of motion development. Its persistence means delay in the maturation of the nervous system and the pyramidal path which even if not in a permanent manner but may cause definite lags. According to Sally Goddard, the infant-age reflexes never really pass away but they get blocked in the first few months of life by the development of more advanced cerebral areas. They might remain active however if these areas get damaged in the early age (p.e. Little's disease) or when an accident/injury happens (p.e. after cerebral haemorrhage at head injury) in later age or if degenerative diseases of the central nervous system (sclerosis multiplex, Alzheimer's disease) occur. 
As per medical theory infant-age reflexes may not remain active at the majority of people after the age of 6 months. Yet if they can be called forth then it is a sign of a larval pathological state. More and more recent evidenceshowever imply that the traces of primitive reflexes (remaining reflexes) might stay active at lot of people even with no recognizable diseases. (McPhillips et al. 2000; Goddard Blythe, 2001; McPhillips and Sheehy, 2004; Taylor et al. 2004; Goddard Blythe, 2005; McPhillips and Jordan-Black, 2007). An embryological questionnaire compiled by the Chester Institute of Neuro-Physiological Psychology and applied for more than 30 years consistently show that in case of group occurrence of specific circumstances (medical problems during pregnancy or childbirth, retarded progress in the first 12 months etc.....) the child has bigger chance to keep the early reflexes leading to negative influences in the school performance. (Goddard Blythe and Hyland, 1998)." We can say thatthe persistent ubiety of primitive reflexes at children above the age of 6 months is the clear indicator of neuromotor immaturity which hampers the process of learning both individually and in group.

„The experience of the first sight, the first touch, the first pleasure do not denote a sort of material content but it does open up a new dimension which will never be closed anymore, outspread a horizon, a background and all later experiences shall be positioned compared to them." (Maurice Merleau-Ponty 2007, 171) If this experience is deficient or hurt, it may cause abiding or re-occurring difficulties in the child's life.

\section{The body is an intersubjective system}

In phenomenology the objectivity of the body does not exist in itself but only in interaction with the subjective body. It is very interesting that in the first period of life the child also experiences this same state of ,intersubjective constitution” (Husserl 2000, 115). This is the first experience in LIFE. The discovery of the own body, my body, not my body. I already know it but still I don't know it yet, I keep learning day-by-day more and more about it yet it is unknown. This is a ball. I touched it. The hand touched it. Did my hand touch it? What is my hand? Is this my hand? This is my hand. In this cognition process reflexes help a lot. These involuntary motions shall assist first the child's experience then later it will break away to expressions like the body, motion, hand, foot, move, lift, jump, object, ball, outside world etc. This is the way how the body's norm-creating function,the notions, the extents get sense and become internal. I am able to perceive my hand with my other hand, my eye with my handthrough which an active organ will become an object while an object will be transformed into an active organ as described by Husserl the game practised by the child in the first years of age and maybe throughout a whole life. Utilizing this experience the INPP training program produces more and more precise recognition about the body in subjectiveand objectivereality through the exercise of the various phases of motion progress in the new-born age, the deliberate re-experiencing of themand the deliberate body training while the body shall also get to know itself more deeply. ,.... during the unfolding of self, it will conceive its own „world" from ,inside" while on the other hand by pervading the world recognizes itself as member of the world's externalities and makes difference between the „outer world" and itself." (Edmund Husserl, 2000) During the conscious re-learning of the motion program these experiences - the subjective and objective ones - shall be positively confirmed which is the route of awareness and at the same time a learning-enhancing program and training of the nervous system through its own kinestatic experiences.Learning in my own body and about my own body. With the passing of time this game shall have less and less importance in human life. The typical childhood process of learning through action is not the classical interpretation of learning but it is a continuous, playful, spontaneous way of gaining experiences where the objective and subjective world gets mixed up. This is the game between the body, body members, tract systems and the outside world. In this age the body 
experiences and stimuli from the outside world are processed mainly in a playful, spontaneous manner to become later more organized and controlled in the school environment. During the reflex correctional motion program by re-living the neonatal age motions, the child shall live through again the phases of remembrance, reproduction, re-learning, extinction.

As I already mentioned the development of the motoric abilities stems from common effect of the body regulation, the sensomotoric relationships and the intersubjective interaction. This process cannot be riven because it is a dynamic system ensuring the subjectivity of the body experience and the optimal motion progress.

\section{REFERENCES}

Boda, Domokos, (1985). Pediatrics Budapest. Medicina ISBN: 9632413644

Goddard, Sally. (2006). Reflexes, Learning and Behaviour. Budapest, Medicina ISBN: 9632260716

Goddard, Sally. (2009). The Well-Balanced Child. Budapest, Medicina ISBN: 9789632262581

Horváth, Lajos. (2011/11). Neurophenomenology and the Incarnated Mind. Hungarian Science

Husserl, Edmund. (2000). Cartesian Speculations. Budapest Atlantisz ISBN: 963916545X

Merleau-Ponty, Maurice. (2007). The Visible and the Invisible. Budapest, L'Harmattan ISBN: $963968323 \mathrm{X}$

Nietzsche, Friedrich. (1908). Thus Spoke Zarathustra. Budapest, Károly Grill Publishing House ISBN: 9360192616 


\section{METHODOLOGICAL STUDIES}




\title{
ANALYZING THE FACTORS INFLUENCING HEALTH BEHAVIOR IN CHILDHOOD - THE IMPACT OF MEDIA- AND COMPUTER USAGE ON HEALTH BEHAVIOR ${ }^{5}$
}

\author{
Authors: \\ Tamás Józsa \\ University of Debrecen \\ Beáta Erika Nagy \\ University of Debrecen
}

E-mail address of the first author: tamasjozsa@med.unideb.hu

\section{Lectors:}

Éva Szabó

Kenézy Gyula Kórház és Rendelőintézet

Veronika Schéder

University of Debrecen

Ferenc Mező

Eszterházy Károly University

Edina Szabó

University of Debrecen

Józsa, Tamás and Nagy, Beáta Erika (2017): Analyzing the factors influencing health behavior in childhood - the impact of media- and computer usage on health behavior. Különleges Bánásmód, III. évf. 2017/1. szám, 61-67. DOI 10.18458/KB.2017.1.61

\begin{abstract}
According to WHO a new integrative mindset became relevant nowadays which sees people as bio-psycho-social-spiritual wholes. These factors start to form in childhood and those who work with people have a great responsibility to help deploying them. The media and the internet have a main role of influencing these 4 dimensions. In our article we attempt to reveal the effects of this psychologically relevant question on health behavior. Several risk behaviors can be mentioned which are caused by uncontrolled media and internet usage. Bullying through electronic devices („cyberbullying”) occurs more and more frequently which has multiple reasons. Nevertheless in connection with the social dimension of well-being an important cause of internet usage appears: the sense of belonging. The formation of health psychology was legitimate as the biomedical model failed and the expenses of health care and the interest towards the quality of life increased, also alternative solutions became more in demand.
\end{abstract}

Keywords: bio-psycho-social-spiritual integrative aspect, health behavior, media- and computer usage, health psychology

Disciplines: psychology, health psychology, communication and media studies

\footnotetext{
${ }^{5}$ The editorial board does not take any responsibilty for the English of the papers. Indeed, we made some slight changes but wanted to keep the style of the authors.
} 


\section{Absztrakt}

Napjainkban az ember bio-pszicho-szocio-spirituális modellben képzelendő el. Ez a WHO által közzétett állásfoglalás aláhúzza, hogy mindezen 4 dimenzió formálódása már gyermekkorban megkezdődik, és kialakulásukban nagy szerepe van a segítő szakmákban dolgozóknak. Ebben a cikkben azt hangsúlyozzuk, hogy az internet és a média milyen kulcsfontosságú szerepet tölt be az egészségmagatartás formálódásában. A különféle médiumok kontrollálatlan fogyasztása, a közösségi média rohamos terjedése (aminek oka a valahová tartozás érzésének elsődlegessége), valamint a cyberbullying jelensége egyaránt lépések megtételére sarkallja a pszichológusokat. Mindennek - és a biomedikális modell kudarcának - köszönhetően megszületett egy új szubdiszciplína, amelynek küldetése nem más, mint az életminőséggel történő fokozott foglalkozás, valamint a napjaink életszemléletéhez igazodó alternatív megoldások keresése.

Kulcsszavak: bio-pszicho-szocio-spirituális emberkép, egészségmagatartás, média- és számítógép-használat, egészségpszichológia

Diszciplína: pszichológia, egészségpszichológia, kommunikáció és médiatudomány

\section{THE RELEVANCE OF HEALTH BEHAVIOR AS A DISCIPLINE OF SCIENCE}

The term health psychology includes all aspects of psychology connected to health, illness, health protection and politics (Kulcsár, 2002). Studies with a positive psychology approach have a relevant role among the topics of current researches which decisively influenced the approach of health psychology. The formation of health psychology was legitimate as the biomedical model failed and the expenses of health care and the interest towards the quality of life increased, also alternative solutions became more in demand. An important goal of health psychology is prevention and education which was also our approach for this study. There's a need to identify the so called behavior pathogens which negatively influence people's health behavior as they are risk factors. Moreover it' recommended to consider not only people's environment where they lived and worked, which had a correlation to their illness but also the surroundings of the treatment. The health and illness patterns have a significant impact on one's representation (their cognitive construct, their interpretation of their health and illness). Basically two kinds of approach have to be mentioned: according to the negative definition the lack of illness is health, but the positive approach declares that something more, something extra is needed for complete health. All these are beliefs and expectations which influence healing without a doubt although doctors who treat physical symptoms can't consider these due to lack of time, resources and expertise (Diefenbach et. al., 2008). The compliance, adherence and the communication with the doctor and the medical staff are all vital aspects in connection with cooperation and decision making. In childhood the parent's attitude towards the illness is also relevant as the adults who could change their lifestyles after a serious illness did correctly detect their own roles in the formation of the illness (i.e. obesity leads to cardiological disorders). This appropriate detection of the causes led to a more efficient loss of their bad habits, more efficient than those who "only" had the doctor's advice to get rid of their bad habits (Michie, Miles \& Weinman, 2003).

Health psychology needs to examine which secondary psychological disorders can join or influence physical diseases. Education and support is vital for those who suffer from chronic diseases and for their family (Csabai \& Molnár, 2009). Health orientation is a key concept although in connection with it Freud's foundations and theories need to be reconsidered. Freud's negative view of human nature is not actual anymore as the post material values have a better impact on health than the possessions of the consumer society (Pikó, 2004). These 
values can be the feeling of belonging somewhere, the possibility of self-realization or finding that life has a meaning (Zonda \& Paksi, 2006). All these suggest an integrative concept in which people exist in a bio-psycho-social-spiritual whole - as the WHO also declares. These dimensions can facilitate the emergence and maintenance of the correct health behavior individually. The formation of these starts at childhood, also teachers, psychologists and people with other social carriers have a great role in its developing. Media and internet have an even bigger influence on it though. These are capable of concentrating all 4 aspects, the physical-psychical-social-spiritual dimensions and taking effect on children often unnoticed by the parents, several times a day.

\section{THE HUMAN HEALTH BEHAVIOR AND ITS INFLUENCING ASPECTS}

Any behavior which helps maintaining health or prevents illness according to the person is considered to be health behavior. In its developing important times are early childhood and adolescence (the critical sense is absent or opened). The internalizing of patterns happens from the family, institutions and the media. We have to mention that conscious health behavior increases in adulthood and with aging (Kulcsár, 2002). Gender differences can be detected regarding health behavior. Men are more likely to be passive during treatment (,the doctor knows better") also the staff sees that men's feedback and general attitude is more positive. Women however are more interested in the details of their illness, they're usually well informed and also it's easier for them to share their feelings. Some disorders which could be partly avoidable with education and providing information (in one word: prevention) can emerge due to a low social-economical status. Those who have a low level of SES can be described with worse health habits (i.e. smoking and alcohol), less information regarding alternative stress management techniques, different cognition of diseases, endangering behavior during pregnancies, etc. (Kulcsár, 2002). All these attitudes of parents influence the children too, who can carry these patterns. In connection with this and gender differences we mentioned before there's the fact that women usually go to doctors sooner if they have somatic reactions to stress which is caused by the society accepts women's sensitivity more. This is relevant to us as little girls had more emotional support when they showed signs of physical or emotional weakness so women have a chance to have a health behavior that includes social support. On the other hand boys are less likely to have social support, they won't care about prevention and will be most likely to belittle the first signs of illness (Csabai \& Molnár, 2009).

Back to media: it can be interesting to analyze the aspects we discussed above and the role of media more closely, as its effect grown so much that a commercial, a billboard or a TV show can have a significant impact on a child's health and illness pattern or health behavior.

\section{THE IMPACT OF MEDIA AND INTERNET USAGE ON PHYSICAL HEALTH INDEX}

Spending several hours in front of the screen takes time away from exercising which would be essential for maintaining health and the body. The fixed posture of using electrionical devices (sitting in a same position for a long time) can have a negative effect on the spine and the back. The lack of sport is an effective predictor of early death (Kopp \& Skrabski, 2009). Young people who don't do sports are less satisfied with their lives, they have lower self esteem and they experience more symptoms of depression (Pluhár, Keresztes \& Pikó, 2004). Moreover neglecting the physical dimension may lead to secondary psychic disorders (Pikó \& Keresztes, 2007). The term 'couch potato' refers to the fact youngsters have an inactive lifestyle due to constant internet usage and watching too much TV (Tapscott, 2001). 
Therefore it's vital to highlight the undeniable benefits of regular exercise in childhood. Media's role can be providing easily accessible information or inspiration in connection with popular sport events and outstanding achievements (O'Keeffe \& Clarke-Pearson, 2011).

We have to point out that in childhood sport is not mentioned as a significant aspect on its own. From a preventive point of view there are four groups of advices regarding how to avoid illness. The first group mentions the environment/weather (e.g. not to go outside when it's cold), the second talks about diet (e.g. not to eat bad quality food), the third group is about avoiding infection (e.g. the importance of washing hands) and the fourth one implies a general healthy lifestyle. This last one becomes more important with aging, there's a tendency of ignoring the actual rules and turning towards more abstract behaviors (Hansdottir \& Malcarne, 1998).For adults making efforts to enjoy the health protecting effects of sport can be a reasonable goal. Sport can also be corrective and may have vital role in healing after a disease. Physiotherapy and physical rehabilitation are necessary after an illness in order to heal, recover and get reintegrated into society as fast as possible. Even in cases where the attitude towards one's own body needs to be reevaluated exercise is still important (e.g. after losing a limb there's the possibility of para sports). After a crisis team sports can help rebuilding social dimensions: it provides space to socialize, increases self acceptance, and calls forth adequate psychical reactions (Csabai \& Molnár, 2009).

\section{THE IMPACT OF MEDIA AND INTERNET USAGE ON MENTAL HYGIENE}

A recent study's focus was on the parent's control of the children's media- and internet usage. It revealed that the majority of the parents don't restrict the children's internet usage in any way (personally or with the help of a software) (Mihalik, Szabó \& Kovács, 2014). This questions the quality of their attachment as the lack of control gives the kids power which they shouldn't have because of their age. Moreover the regular consummation of inappropriate contents can lead to depression, anxiety or mortal fear. The reason of this is that they are only observers, they can't process the stimuli properly without the presence of a grown up they're attached to (Tapscott, 2001). Regarding educational psychology the importance of this is based on that during free interactions between children topics like reality shows, talk shows and late night shows occur regularly which claims an appropriate reaction due to the children's mental health protection. In many cases parents use technical devices as a part of punishing-rewarding attitude, causing immunity in the children towards nonverbal communication, touching, storytelling and parent-children playtime. These justify interventions from professionals. More risk behavior could be mentioned due to uncontrolled media and internet usage, such as body image disorder (Nystrom, 2005). The body image presented to the consumer by the media is almost always perfect. It rarely happens that a disabled or handicapped celebrity or actor/actress appears on the screen which leads to influencing children's self esteem significantly. We mentioned the importance of social support in connection with sports and physical consequences of an illness. It's just as important (or it should be) that people who're not perfect can appear in the right mediums. Nick Vujicic's world tours are the perfect example: the young man with Serbian roots has no limbs yet he talks honestly about his difficulties and his place in society (how his classmates treated him, how could he fit in). He even mentions serious subjects as suicide, and his aim is to make the audience feel that they're not alone with their problems and they can live a full life even with disabilities. He's trying to inspire and not aiming to elicit sympathy or pity. From a preventive point of view it is important that watching TV or using the internet together with the parent can be interpreted as an attachment building and cohesive mechanism (Mihalik et. al., 2014). Individual but remotely controlled internet usage increases relevant mental aspects: correct self representation, self efficacy and impulse control can develop 
(Milkie, 1999). The feeling of competency is substantial in the cases of children who don't achieve as much at school as others (due to any reason: for example studying disorder or a low level of socialization). These children can be compensated due to the success they can achieve in the field of IT (Ryan \& Deci, 2000).

\section{THE IMPACT OF MEDIA AND INTERNET USAGE ON SOCIAL DIMENSIONS}

Cyberbullying, i.e. harassing someone through electronical devices or social media is more and more frequent which fact has various reasons. Some of these are the not age-appropriate content, the unsatisfying parental control, and the anonymity joined with the spread of chat sites and softwares. There are no consequences of foulmouthed description of others which lets „trolls” appear and spread on the internet (Wallace, 2006). At this point we have to consider the system in which the person exists: the social milieu from where the person acquires his/her culture (of conflicts) (Domonkos, 2014). The victim is usually passive, has low self esteem and socially marginalized in real life (Gradinger, Strohmeier \& Spiel, 2009). However the aspect of belonging somewhere is the main reason young people name in connection with internet and media usage. This feeling is a motivational factor connected to the social aspect of well-being (Wan \& Chiou, 2006). Belonging is a major factor in playing online multiplayer games: the players frequently communicate in 'real time', with the help of microphones while playing which provides an experience similar to personal presence (Zermatten et. al. 2011). This can have a positive effect if they can maintain the relationship in real life (for example online friendships based on comradeship can continue at school too). The social support can appear during play by the instant feedback: e.g. complimenting a good shot, a movement, etc. and expressing that the person is "good as a whole". This is based on the fact that accomplishment-based valuation is common among children: if you play well, you're a good person. You're good and acceptable as a person, not you're accomplishment. Due to this youngsters can get into situations where they act condemned by the society (e.g. cyberbullying expected by the others) to satisfy the decreased value of their own negative schema. It's important that social support and acceptance can have an impact on health behavior: the mortality of married couples is better than unmarried people's (Csabai \& Molnár, 2009).

\section{THE IMPACT OF MEDIA AND INTERNET USAGE ON THE SPIRITUAL DIMENSION}

Several studies indicated that people who believe life has a meaning or who think a greater force exists with protective will are more efficient in solving problems and can cooperate better (Kopp, Székely \& Skrabski, 2004). Supportive groups (such as online grief support groups) can help working through a trauma as they widen the social network (Tomcsányi \& Ittzés, 2010). Connection and consolation can provide coherence even at hard times (Idler et. al., 2003). Working through grief is a topic of health psychology: the person suffering from pathologic grief can find help by contacting a professional. At the end-stage of a chronic disease the person and the family can be prepared for the process, their ability to face the inevitable develops, this way they took the first step of their psychical health protection. Working through grief which can turn into a pathological grief process can take lots of time and requires active work from the family. What can help are the transpersonality, the feeling that life has a meaning or the method of logotherapy which originates from the theory of existentialism can also ease bearing the negative processes. The essence of the method Viktor E. Frankl created is that the person must look at his/her life in a perspective, as it was outgrowing him/her so it's easier to cope with irreversible losses, pain, difficulties and not 
only the person's health behavior but also his/her general mental state will improve and be more positive. The resilience is a factor which influences health behavior relevantly. This means people can adapt to a continuous, negative, tendency-like life event and still be mentally healthy when it's over (Davydov et. al., 2010). Corrective experiences (when a person can meet others with similar problems and can keep track of their healing) can offer potential to reach inner strength. A negative aspect of the spiritual dimension can be that a person might be the victim of „facelessness”. „Impersonation” happens more and more frequently: some can elicit personal data, pictures, etc. from the passive victim and then use their profiles and online contents (Willard, 2007). Joining a virtual sect or opening up to a person with an agenda can lead back to the problems of using the internet unsupervised and the pedagogic role and responsibilities of the parents.

\section{CONCLUSION}

The preventive aspects of health psychology are extremely important these days, such as the aspect of education. Besides the practical usage parents and educators can benefit from the theory and can bring up a generation whose health behavior will be more positive and healthier. Media and internet usage have a great role in this. Children use their devices all day and they also watch TV, listen to the radio which without parental control which can result in negative tendencies due to passive consummation and having online relationships instead of real life ones. It's vital to detect these and to emphasize the protective factors of media usage: using devices of modern technology may make life and learning easier, also it can widen the world if media is properly used. This way media can be a tool of increasing well-being or protecting our mental health. Moreover it's important to acknowledge that neglected aspects connected to childhood health behavior, health and illness patterns, behavior pathologies and other risk factors are specifically influenced and can improved by the media. The preventive approach of health psychology is not only cost-efficient and effective but also extremely useful for education and providing information which from professionals and others can both benefit. The usability of the data and theories at early ages can significantly contribute to create a better, more peaceful and health conscious world.

\section{REFERENCES}

Davydov, D. M., Stewart, R., Ritchie, K., \& Chaudieu, I. (2010). Resilience and mental health. Clinical Psychology Review, 30(5), 479-495.

Diefenback, M. A., Suzanne M. M., Porter, M., Peters E., Stefanek, M., \& Leventhal, H. (2008). Emotions and Health Behavior: A Self-Regulation Perspective. In M. Lewis, J. M. Haviland-Jones \& L. F. Barrett, Handbook of Emotions (pp. 645-60). New York: The Guilford Press

Domonkos, K. (2014). Cyberbullying: harassing with electronical devices (Cyberbullying: zaklatás elektronikus eszközök használatával). Alkalmazott Pszichológia, 1, 59-70.

Gradinger, P., Strohmeier, D., \& Spiel, C. (2009). Traditional bullying and cyberbullying. Zeitschrift für Psychologie/Journal of Psychology, 217(4), 205-213.

Hansdottir, I., \& Malcarne, V. L. (1998). Concepts of illness in Icelandic children. Journal of Pediatric Psychology, 23(3), 187-195.

Idler, E. L., Musick, M. A., Ellison, C. G., George, L. K., Krause, N., Ory, M. G., et al. (2003). Measuring Multiple Dimensions of Religion and Spirituality for Health Research. Research on Aging, 25(4), 327-365.

Kopp, M., \& Skrabski, Á. (2009). Hungarian state of mind after the Millennium (Magyar lelkiállapot az ezredforduló után). Távlatok, 86, 32-53. 
Kopp, M., Székely, A., \& Skrabski, Á. (2004). Religiousness and health in the changing society (Vallásosság és egészség az átalakuló társadalomban). Mentálhigiéné és Pszichoszomatika, 5(2), 104-125.

Kulcsár, Zs. (2002). Health psychology (Egészségpszichológia). Budapest: ELTE Eötvös Kiadó.

Michie, S., Miles, J., \& Weinman, J. (2003). Patient-centredness in chronic illness: what is it and does it matter? Patient Education and Counseling, 51(3), 197-206.

Mihalik, Á., Szabó, É., \& Kovács, P. (2014). The parental control of the children's computer and internet usage (A gyermekek számítógép- és internethasználatának szülői kontrollja). Alkalmazott Pszichológia, 1, 47-58.

Milkie, M. A. (1999). Social comparisons, reflected appraisals, and mass media: The impact of pervasive beauty images on Black and White girls' self-concepts. Social Psychology Quarterly, 190-210.

Molnár, P., \& Csabai, M. (2009). Medical psychology and clinical health psychology (Orvosi pszichológia és klinikai egészségpszichológia). Budapest: Medicina.

Nystrom, A. A., Schmitz, K. H., Perry, C. L., Lytle, L. A., \& Neumark-Sztainer, D (2005). The relationship of weight-related perception goals and behaviors with fruits and vegetable consumption in young adolescents. Preventive Medicine, 40(2), 403-408.

O'Keeffe, G. S., \& Clarke-Pearson, K. (2011). The impact of social media on children, adolescents, and families. Pediatrics, 127(4), 800-804.

Pikó, B. (2004). The mission of positive psychology in the modern society (A pozitív pszichológia missziója a modern társadalomban). Mentálhigiéné és Pszichoszomatika, 5(4), 289-299.

Pikó, B., \& Keresztes, N. (2007). Sport, psyche, health (Sport, lélek, egészség). Budapest: Akadémiai Kiadó.

Pluhár, Zs., Keresztes, N., \& Pikó, B. (2004). The connection of regular physical activity and psychosomatic symptoms regarding primary school students (A rendszeres fizikai aktivitás és a pszichoszomatikus tünetek kapcsolata általános iskolások körében). Sportorvosi Szemle, 4, 285-300.

Ryan, M. R., \& Deci, E. (2000). Self-Determination Theory and the facilitation of intrinsic motivation social development and well-being. American Psychologist, 55(1), 68-78.

Tapscott, D. (2001). Digital childhood. The rise of the internet generation (Digitális gyermekkor. Az internetgeneráció felemelkedése). Budapest: Kossuth Kiadó..

Tomcsányi, T., \& Ittzés, A. (2010). The main questions of studying spirituality and religiousness and the Scale of Spiritual Transcendence by Piedmont (A spiritualitás és vallásosság kutatásának kulcskérdései és a Piedmont-féle Spiritualitási és Vallási Érzület mérőskála). Psychiatria Hungarica, 25(2), 110-120.

Wallace, P. (2006). The psychology of the internet (Az internet pszichológiája). Budapest: Osiris.

Wan, C. S., \& Chiou, W. B. (2006). Why are adolescents addicted to online gaming? An interview study in Taiwan. CyberPsychology \& Behavior, 9(6), 762-766.

Willard, N. E. (2007). Cyber-Safe Kids, Cyber-Savvy Teens, Helping Young People Learn to Use the Internet Safely and Responsibly. San Francisco: Wiley \& Sons Inc.

Zermatten, A., Billieux, J., Thorens, G., Bondolfi, G., Zullino, D., \& Khazaal, Y. (2011). Motivations to play specifically predict excessive involvement in massively multiplayer online role-playing games: evidence from an online survey. European Addiction Research, 17(4), 185-189.

Zonda, T., \& Paksi, B. (2006). Data of the protective factor of religiousness regarding physical and mental health (Adatok a vallásosság protektív szerepéhez a testi és lelki egészségben). Mentálhigiéné és Pszichoszomatika, 7(1), 1-13. 


\title{
MONITORING AND SUPPORTING THE DEVELOPMENT OF CHILDREN AND YOUNG PEOPLE IN THE UNITED KINGDOM ${ }^{6}$
}

\section{Authors:}

Judit Tanczos

University of Debrecen

E-mail address of the first author: tanczos.judit@gmail.com

\section{Lectors:}

Magdolna Nemes

University of Debrecen

Ferenc Mező

Eszterházy Károly University

Veronika Schéder

University of Debrecen

Katalin Mező

University of Debrecen

Tanczos, Judit (2017): Monitoring and supporting the development of children and young people in the united kingdom. Különleges Bánásmód, III. évf. 2017/1. szám, 69-77. DOI 10.18458/KB.2017.1.69

\begin{abstract}
Development is a continuous process influenced by several factors. If practitioners would like to ensure children's and young persons' optimal social and emotional development and school performance, they have to monitor both development and academic achievement from early childhood until the age of 19 . In the UK, more than one million children struggle with speech, language and communication problems so the early identification is of vital importance. If identification is missed or late, it may have detrimental effects on the child's or young person's psychological, mental and physycal health. Multi-agency teams work in collaboration in order to provide the relevant help to those in need.
\end{abstract}

Keywords: factors influencing development, methods of monitoring development, SENCO, early identification of delays and disorders in language development, children in at-risk position, multi-agency approach

Disciplines: developmental psychology, pedagogy

\begin{abstract}
Absztrakt
A fejlődés egy életen át tartó folyamat, melynek menetét számos tényező befolyásolja. Ha a szakemberek biztosítani szeretnék a gyermekek és fiatalok optimális társas és érzelmi
\end{abstract}

\footnotetext{
${ }^{6}$ The editorial board does not take any responsibilty for the English of the papers. Indeed, we made some slight changes but wanted to keep the style of the authors.
} 
fejlödését, valamint iskolai teljesítményét, akkor kora gyermekkortól 19 éves korig monitorozniuk kell e folyamatokat. Az Egyesült Királyságban több mint egy millió gyermek küszködik beszéd-, nyelv- és kommunikációs problémákkal, ezért a korai azonosítás óriási fontossággal bír. Ha e problémák azonosítása késik vagy elmarad, az súlyosan károsíthatja a gyermek, illetve fiatal lelki, mentális és testi egészségét. Számos szakma képviselői együttmüködve biztosítják a megfelelő segítségnyújtást a rászorulóknak.

Kulcsszavak: a fejlődést befolyásoló tényezők, a fejlődés monitorozásának módszerei, a nyelvi fejlődés késésének és zavarainak azonosítása, veszélyeztett gyermekek, multidiszciplináris megközelítés

Diszciplína: fejlődéspszichológia, pedagógia

\section{INTRODUCTION}

Development is a continuous process which lasts throughout our life. The sequence of developmental changes is generally the same among individuals but development doesn't progress at the same rate. For example, most children utter their first words between the age of 1 and 2. Nevertheless, there are children who can say a few words already when they are 7 or 8 month old while others cannot say a word even at the age of 3 .

The knowledge of the difference between sequence and rate is important, because it has to be taken into consideration when

- $\quad$ education is planned and implemented for the different age groups

- $\quad$ education is planned and implemented for talented pupils whose rate of development at a given field can be much faster than that of the peers

- $\quad$ the practitioner meets a child whose development is delayed. The identification of the problem at an early stage enhances the chance of successful intervention.

\section{CLASSIFICATION OF FACTORS INFLUENCING DEVELOPMENT}

We can divide the factors influencing development into two main groups: these are the external and personal factors.

\section{External factors}

The most often studied external factors are poverty, family environment, abuse and care status.

\section{Poverty}

Poverty is a complex phenomenon and can hamper the development of children in multiple ways. It often leads to malnutrition, which can have a detrimental effect on the foetus (if the pregnant mother misses the right kind and amount of food) and later on the intellectual and physical development of the growing child (if they themselves are malnourished). In many cases the reason for poverty is unemployment which can strike generations within a family. If a child grows up in a family where neither the parents nor the grandparents worked ever, it will negatively influence their attitude to achievement (studying and working). The reason for unemployment is often the lack of education of the parents, which results in a less stimulating family environment for the child. It leads to additional negative consequences on the child's intellectual development. A family with a low income cannot afford to live among healthy circumstances (e. g. there may be mould in the flat, no water and electricity, etc.). It may induce illnesses, which slow down physical and intellectual development. Poverty often leads to marital problems, to alcoholism or criminal acts, which seriously damages the emotional 
development and mental health of the child. So we can see that poverty is a multiple risk factor with regard to child development. Moreover, in the majority of cases, it damages development linking together with other negative factors (health problems, negative environmental effects and unhealthy lifestyle).

\section{Family environment}

The role of family is to give love and safety and to convey the norms of socialization towards children. Family is the first medium where the learning of the rules and norms starts for the growing children. If the child's needs for love and safety are not met because of the problematic family relationships at home or if the parents convey inappropriate norms, the child's psychological and/or moral development will be negatively affected.

\section{Abuse}

There are several situations in which the child's or the young person's vulnerability can be misused. The abuse can occur in the family, at school, during outdoor programs etc. It has got different forms among which the most frequent ones are physical, emotional and sexual abuse and neglect. Any form of abuse is severely detrimental on the psychological development of children and young adults (North Yorkshire Safeguarding Children Board, n. d.).

\section{Care status}

According to research conducted among children in care status ( Kools and Kennedy, 2003), this special situation slowed down development in about $60 \%$ of the children concerned. This negative effect could be detected in several areas (e. g. in the development of language, intellectual abilities and motor skills). Generally these children had previously been traumatized before getting into care status as their placement became necessary due to their at-risk situation at home. The detachment from the family was the source of a new trauma, which adversely affected their emotional development.

Living at foster parents' have their drawbacks as well since foster children are often mocked, teased and bullied by their schoolmates. It discourages them even more and they may become outsiders or manifest challenging behaviour at school, which will impair their social development.

Beyond the four factors mentioned above, additional external factors can also influence the process of development. Seifert (n. d.) draws the attention of parents and educational practitioners to the role of media and peers. Children can see programs containing violence on the television, which may enhance their aggression and motivate them to imitate aggressive scenes. Peers have got the strongest influence on each other in adolescence and if a young person gets under the influence of a group of peers with negative values, it can be detrimental to their social and emotional development.

\section{Personal factors}

Development can be influenced by personal factors as well. The most well-known personals factors influencing development are health status, sensory impairment, learning difficulties, genetics and disabilities.

\section{Health status}

The child's actual health status can be affected by several factors. These may be inborn conditions or the onset of acute or chronic diseases. 
Foetal Alcohol Syndrome (FAS) is an example of inborn conditions, which severely effects the child's physical and mental development. If the lips and the palate are deformed, it will cause difficulties in communication, which will result in problems of social development.

In certain cases medicines taken during pregnancy can lead to birth defects. The sedative Thalidome (Human Diseases and Conditions, n. d.) caused birth defects in children whose mothers used this medicine while being pregnant in the 1950-60s. These children were born with very short and underdeveloped limbs, which severely damaged their physical development, self-esteem and the formation of social relationships.

Acute and chronic diseases can be detrimental on the health status of a child later in life as well. Diseases may have a negative impact on the child's intellectual, emotional and social development. If for example a child becomes chronically ill, they can fall behind in studying and lose their friends at school due to the changes in their lifestyles. Even short-term, acute illnesses may cause problems in achievement if they happen repeatedly.

\section{Sensory impairment}

Among sensory impairments it is the damage of vision and hearing which is detrimental to the child's development as the majority of information is perceived through these two sensory channels. Due to the impairment of sight, less information gets into the brain and the formation of coordination between the eyes and hands delays, which have negative consequences on development. Poor hearing may slow down the development of speech and communication, which leads to additional problems: delayed language development negatively affects cognitive development and the formation of social relationships, that is it hinders social development.

\section{Learning difficulties}

If a child's intellectual abilities are intact, the reason for their poor achievement at school may be learning difficulties (e. g. dyslexia, dysgraphia or dyscalculia), dyspraxia or ADHD. The child is hindered by these conditions and will be an underachiever until he gets adequate support. The consequences of the missed or late identification of learning difficulties may be extremely severe to the personal, emotional and social development of the child and may impede their academic achievement and choice of career.

\section{Genetics}

Genetic disorders may impede several areas of development. A well-known chromosomal abnormality is Down syndrome. It causes mental retardation and deviations in speech development. Additional health problems can often be diagnosed, such as special malformations on the face and the tongue, heart failure, decreased muscle tonus etc. (First Signs, n. d.).

\section{Disabilities}

Disabilities can severely impair the child's physical and/or intellectual development depending on the type of the impairment (physical, learning or both). In addition to it, disability can have detrimental effects on the child' emotional and social development as well, e. g. the child cannot socialize with peers as often as it would be desirable or they can be mocked and bullied by other children, which can have an extremely harmful effect on their self-esteem and mental health. The cultural background of the disabled child may also influence the attitudes of the family members towards the child, which can either compensate or strengthen the negative effects mentioned beforehand. There are several developmental disorders which can lead to disability. As indicated by First Signs (n. d.), the most frequent 
developmental disorders in order of priority among schoolchildren in the US are the following: mental retardation, cerebral palsy and autistic spectrum disorder.

Mental retardation

The intellectual abilities of children suffering from mental retardation are below the average. This disability severely damages cognitive development and has a negative impact on the formation of social relationships, learning, choosing profession and starting to live independently.

Cerebral palsy

This is a neurological condition which primarily impairs the development of motor skills but it has a negative influence on the development of speech and of visual and auditive perception as well. Depending on the extent of the damage, the child or young person suffering from cerebral palsy can be limited in their movement only moderately but they can become severely disabled as well.

Autistic spectrum disorder

According to The National Autistic Society (n. d.), autism is a developmental disorder which is severely detrimental on the development of social relationships and communication. It also impairs perception and can cause learning disabilities. It may have mild and severe forms. People with severe forms of autism are unable to live independently.

Beyond the disabilities mentioned above, spina bifida is a developmental disorder often studied. It hampers primarily the gross motor skills as it may lead to the weakening or even the total paralysis of the legs. In most cases spina bifida doesn't affect cognitive development but if it is associated with hydrocephalus, it can lead to learning difficulties. This developmental disorder also causes certain health problems for example urinary and bowel incontinence (NHS choices, n. d.).

\section{An explanation of how to monitor children and young people's development using different methods}

If practitioners would like to ensure children's and young persons' optimal social and emotional development and school performance, they have to monitor both development and academic achievement from early childhood until the age of 19.

According to Southern Early Childhood Association (2000), monitoring methods can be divided into two groups: there are formal and informal methods. Formal methods are more settled and regulated. They are executed with the application of standardized tests within predetermined circumstances. The child's results can be compared to the results of others in the same age group. Examples of formal methods are assessment tests, intelligence and diagnostic tests etc. Informal methods are less strictly regulated and predetermined. They involve e. g. the different types of observational methods and the collection of children's work samples (drawings, paintings, samples of handwriting etc.)

We can classify monitoring methods according to the school setting where they are applied. There are methods that can be used both in primary and secondary schools, e. g. formative and summative assessment, peer assessments, SATS (Standard Assessment Tests) and observations. But 11-plus is applied only on primary level while CATs (Cognitive Ability Tests) and GCSE are used only on secondary level.

The most frequently used formal monitoring methods are formative and summative assessment. 
Formative assessment enables teachers to trace the child's academic progress throughout the whole school-year. Its advantage is that it gives the possibility for the early identification of problems (e. g. formal test writing). In contrast, summative assessment evaluates learning only at the end of the school-year. It shows whether the child has reached their previously determined academic goals. The results of both methods are highly informative for the pupils, the teachers and the parents as well.

Among the informal methods, it is observations which are the most often applied for monitoring.

During observations the practitioner observes a child's activities (behaviour, leisure activities, playing, studying etc.) in different situations. The main types of observation methods are the following:

Time sampling: we divide a certain amount of time into intervals with equal length and record at the end of each interval whether the given behaviour has or has not happened. The aim is to identify the possible problem(s). Its advantage is that we can see the frequency of the behaviour so we can decide whether our preoccupation was right or not (Project PARA, n. d., Department of Education and Skills Standard Unit, 2005).

Event sampling: Whenever a predetermined behaviour occurs within a certain period of time (e. g. a week), we record the event. It shows the frequency of the given behaviour. a special type of this method (the ABC Chart) is suitable for exploring the antecedents as well. In the possession of the information, we can plan the modification of the problematic behaviour e. g. by ceasing the causes which triggered it (Department of Education and Skills Standard Unit, 2005).

Free narrative: In a certain period of time, we observe everything in detail and record the events and behaviours as they happened one after the other. Generally we make the observation because of a special reason. The advantage of the method is that it helps to understand the context of the behaviour, too.

Target child observation: It is similar to free narrative but with the help of this method, we observe a particular child within a given period and record everything related to him in detail (their behaviour, interactions, verbal and nonverbal communication etc.).

Anecdotal record: It is the detailed follow-up recording of a particular event related to a given child. We focus only on the behaviour we are concerned about. If we make anecdotal records several times subsequently, it is suitable for the tracing of the development of the given child (Project PARA, n. d.).

\section{An explanation of how different types of interventions can promote development}

There are several ways to help a child if their development fails to follow the expected pattern. Practitioners of different fields work together applying a multi-agency approach in supporting children and young persons struggling with developmental issues. They collaborate with the parents as well, providing them with detailed information about the problem and with advice on how to take part in the support or therapy of their child. Practitioners working outside the school setting are in constant relationship with the given child's teachers, teaching assistants and the SENCO (Special Educational Needs Coordinator), providing them with help and guidance in the planning and implementation of intervention.

The process of intervention is the following: if a teacher or a teaching assistant have concerns about a child's development, they ask for the help of the SENCO, who is responsible for children with special educational needs within the school setting. The SENCO will get in touch with the professionals of different agencies and services whose intervention is relevant in the given situation. The SENCO has a main role in the coordination of the efforts of the school staff, of the professionals working in the multidisciplinary team and of the parents. 
Depending on the child's problem, the intervention of the following professionals can promote development most effectively:

- Speech, language and communication problems: speech and language therapists (SLT)

- Physical health issues (e. g. diabetes, asthma etc.): health visitors (for children between the age of 0 to 5 ) or nurse specialists (for older children)

- Mental health issues: psychiatrists

- $\quad$ Learning or behaviour problems: educational psychologists

- $\quad$ Problems of gross motor skills (e. g. cerebral palsy, spina bifida): physiotherapists

- $\quad$ Social care problems (e. g. difficult home situations, care status): social workers

- $\quad$ Being at risk of exclusion (e. g. vulnerable children): youth justice workers.

An analysis that shows the importance of early identification of speech, language and communication delays and disorders, and the potential risks of late recognition

According to the Royal College of Speech and Language Therapists (2007), communication disorders are the most frequent disorders in early childhood. Approximately $10 \%$ of the children struggles with speech, language and communication problems in the UK, which means more than 1 million children (The Communication Trust, 2012). As identified by the American Speech -Language- Hearing Association (n. d.), the early signs of these problems are the following: a, the child hasn't started to speak by the age of one, $b$, the speech is not clear and c, the child's speech is not similar to that of the children of the same age.

The early identification of speech, language and communication problems is of vital importance, the earlier they are recognized, the more effective their treatment can be. Early recognition and treatment can prevent the damage of development caused by the unsolved language disorders.

As stated by the American Speech -Language- Hearing Association (n. d.), the identification of the disorders can take place even under the age of three in the following cases:

$a$, in the case of children showing the symptoms of disturbed language development or $b$, in the case of at-risk children whose speech, language or communication development may delay or who have a disability related to these areas of development. Children especially being in at-risk position are:

- premature infants

- $\quad$ children with biological factors (e. g. FAS syndrome)

- $\quad$ children with genetic disorders (e. g. Down syndrome)

- $\quad$ children with medical conditions (e. g. asthma, recurrent ear inflammations)

- $\quad$ children with neurological conditions (e. g. cerebral palsy).

However, if the child's problem remains unrecognized and the child doesn't get the appropriate help until the age of five, it will result in the severe impairment of written and spoken language in most cases. At one-third of those who struggle with difficulties in communication, some mental illness will also develop after a time. Due to communicational problems and mental illness, these children or young persons will often become outcasts and commit criminal acts (Royal College of Speech \& Language Therapists, 2007).

The vast majority of children with learning disability have speech, communication and language problems. The late identification of the learning disability and the language development disorder may lead to severe negative consequences. The child's lagging behind at school slows down their cognitive development, the parents and the teachers are discontented and disappointed with the child's school performance, which leads to loss of self- 
esteem, anxiety and anger in the child. Poor achievement at school will impede the young person's entering into high school or choosing the adequate profession. Due to these failures the young person's personality development may take a negative direction and it may lead to antisocial or self-destructing behaviours such as aggression, offending the law or drug abuse (Dyslexia International, n. d.).

These findings clearly show the importance of early identification and intervention. If identification is missed or late, it may have a detrimental effect on the child's or young person's

- $\quad$ intellectual development (as language and thinking develops in interaction with each other)

- emotional and social development (communication problems lead to disruptions in social relationships, which results in serious emotional problems)

- $\quad$ lagging behind at school, which hinders the progressing to secondary school, choosing vocation and getting a job

- $\quad$ mental and physical health (due to the problems mentioned beforehand, mental illness and drug addiction can develop).

\section{An explanation of how multi-agency teams work together to support speech, language and communication}

Multi-agency working is a holistic approach of supporting children and young persons struggling with speech, language and communication problems. It is the collaboration of different services, agencies and experts who work together in order to provide the relevant help to those in need.

The multidisciplinary team consists of professionals from the educational, health and social care sector. If it is necessary, experts of the criminal justice sector can also participate in the work. Every multi-agency team has a leader, the so called lead professional who coordinates the work and with whom the child and their parents can maintain the relationship (Meggitt et al., 2012, p. 216). The key person of the team is the Speech and Language Therapist who cooperates with

- $\quad$ clinicians, health visitors and nurses (health care)

- $\quad$ nursery and school teachers, nursery and teaching assistants, SENCO (education)

social workers (social care), etc. (Royal College of Speech \& Language Therapists (2007).

These professionals come together, share the information related to the given child's case and plan the methods and steps of intervention, in which the role of each professional participant is established. During their collaboration, they regularly discuss their experiences, evaluate progress and support each other's work in order to solve the child's speech, language and communication problem and promote their mental health and emotional well-being. They also maintain the relationship with the child's parents or even ask them to participate actively in the child's therapy (C4EO, n. d.).

Since 2012, multi-agency working for supporting children and young people with speech, language and communication problems has been greatly enhanced by The Communication Trust in the UK. It is a coalition of almost 50 voluntary organizations and advisory groups working on this area (The Communication Trust, 2012).

\section{SUMMARY}

Human development is a complicated and complex process. Several factors can influence this process by fastening, slowing down or even temporarily stopping it. The knowledge of these factors is essential for professionals working with children and young adults as it 
provides the necessary theoretical basis to the successful support of the development of the young generation. By using different monitoring methods, practitioners can ensure children's and young persons' optimal social and emotional development and school performance. If intervention is needed, multi-agency teams work together and provide the relevant help to solve the problem.

\section{REFERENCES}

American Speech -Language- Hearing Association (n. d.) Early Identification of SpeechLanguage Delays and Disorders http://www.ldonline.org/article/6231/ (Download: 24.03.2015)

C4EO (n. d.) Early Intervention. (Download: 25.03.2015). (Web: http://archive.c4eo.org.uk/themes/earlyintervention/vlpdetails.aspx?lpeid=46).

Department of Education and Skills Standard Unit (2005) Observation Booklet 7c (Download:

29.03.2015).(Web:http://tlp.excellencegateway.org.uk/resource/SHD_6013Q/screens/down loads/booklet_7c.pdf).

Dyslexia International (n. d.) The Problem. (Download: 24.03.2015). (Web:http://www.dyslexia-international.org/the-problem/).

First Signs (n. d.) Other Developmental and Behavioral Disorders (Download: 12.03.2015). (Web: http://www.firstsigns.org/delays_disorders/other_disorders.htm).

Human Diseases and Conditions (n. d.) Birth Defects (Download: 12.03.2015). (Web: http://www.humanillnesses.com/original/At-Ca/Birth-Defects.html).

Kools, S., Kennedy, C. (2003) Foster Child Health and Development: Implications for Primary Care. Pediatric Nursing 29(1) (Download: 12.03.2015). (Web: http://www.medscape.com/viewarticle/449673_4).

Meggitt, C., Bruce,T., Grenier, J. (2012) Child Care and Education. Second Edition. London: Hodder Education, An Hachette UK Company.

NHS choices (n. d.) Spina bifida (Download: 17.03.15). (Web: http://www.nhs.uk/conditions/Spina-bifida/Pages/Introduction.aspx).

North Yorkshire Safeguarding Children Board (n. d.) What is child abuse? (Download:12.03.2015). (Web: http://www.safeguardingchildren.co.uk/section-1.html).

Project PARA (n. d.) Observation Techniques (Download: 29.03.2015). (Web: http://para.unl.edu/legacy/Observation/lesson4.php).

Royal College of Speech \& Language Therapists (2007) Speaking out: early intervention for young children with communication difficulties (Download: 24.03.2015) (Web: http://www.speech.derbys.nhs.uk/documents/RCSLTPaliamentaryflyer3.pdf).

Seifert, C. (n. d.) How Children's Development Is Influenced by External Factors (Download 12.03.2015). (Web: http://everydaylife.globalpost.com/childrens-development-influencedexternal-factors-6727.html).

Southern Early Childhood Association (2000) Assessing Development and Learning in Young Children (Download: 27.03.2015). (Web: http://www.southernearlychildhood.org/upload/pdf/Assessing_Development.pdf)

The Communication Trust (2012) Cracking Communication November 2012 Workshop Sessions (Download: 27.03.2015). (Web: http://www.thecommunicationtrust.org.uk/aboutthe-trust/previous-projects/conference/november-2012-workshop-sessions/).

The National Autistic Society (n. d.) What is autism? (Download: 16.03.2015). (Web: http://www.autism.org.uk/about-autism/autism-and-asperger-syndrome-anintroduction/what-is-autism.aspx). 


\title{
IMPROVEMENT OF FINE MOTOR SKILLS IN CEREBRAL PARETIC PATIENTS ${ }^{7}$
}

\author{
Authors: \\ Réka Tóth \\ University of Debrecen \\ E-mail address of the first author: \\ tothreka038@gmail.com
}

Lectors:

\author{
Zsuzsanna Vekerdy-Nagy \\ University of Debrecen
}

Annamária Balóné Jóna

University of Debrecen

Veronika Schéder

University of Debrecen

Katalin Mezö

University of Debrecen

Tóth, Réka (2017): Improvement of fine motor skills in cerebral paretic patients. Különleges Bánásmód, III. évf. 2017/1. szám, 79-85. DOI 10.18458/KB.2017.1.79

\begin{abstract}
The aim of this review is to give an overview about the ADL functions in children and young adults with cerebral palsy and our planned studies. For measuring the ADL functions, the Functional Independence Measure (FIM) and the Functional Independence Measure for Children (WeeFIM) will be used. The hand functions will be analysed by the Quality of Upper Extremity Skills Test (QUEST). The fine motor skills of the hand will be revealed by using the selected subtests of the Bruininks-Oseretsky Test of Motor Proficiency (BOT-2). Based on the outcomes of the measures, a complex therapeutic protocol will be implemented including the elements of the ergo and manual therapy, proprioceptive neuromuscular facilitation (PNF), and piano therapy. It is anticipated that the complex therapy adapted to individual needs will result in significant improvement in the ADL functions in disabled children and young adults.
\end{abstract}

Keywords: children, cerebral paresis, hand, ADL, FIM, BOT2, ICF, physiotherapy

Disciplines: physiotherapy, neurology, rehabilitation

\section{Absztrakt}

Az összefoglaló közlemény célja, hogy áttekintést adjon idegrendszeri sérüléssel, speciálisan cerebrális paresissel élő gyermekek és fiatal felnőttek ADL funkcióiról. Az ADL funkciók mérésére a Functional Independece Measure-t (FIM) ill. annak gyerekekre adaptál változatát (WeeFIM), a kézfunkciók vizsgálatára a Quality of Upper Extremity Skills Test

\footnotetext{
${ }^{7}$ The editorial board does not take any responsibilty for the English of the papers. Indeed, we made some slight changes but wanted to keep the style of the authors.
} 
(QUEST) használatát tervezzük. A kéz finommotoros funkcióit a Bruininks-Oseretsky Test of Motor Proficiency (BOT-2) releváns alkategóriájának használatával kívánjuk vizsgálni. A továbbiakban figyelembe vesszük az ADL funkciókkal kapcsolatos eredményeket és a páciensek preferenciáit A mérési eredmények alapján egy komplex terápiás protokollt fogunk kidolgozni, ami ergoterápiás és manuál terápiás elemeket, proprioceptív neuromusculáris facilitációt (PNF), és zongora terápiás elemeket foglal magába. Feltételezzük, hogy a személyes szükségletekhez igazított komplex mozgásterápia szignifikáns javulást fog eredményezni az ADL funkciók és az életminőség területén a mozgássérült gyerekeknél és fiatal felnőtteknél.

Kulcsszavak: gyerekek, cerebral paresis, kéz, ADL, FIM, BOT2, ICF, fizikotherápia

Diszciplína: fizikotherápia, neurológia, rehabilitáció

\section{INTRODUCTION}

The impaired activities of daily living (ADL) functions (eating, bathing, dressing, toileting, transferring and continence) significantly alter the quality of life in every age group. In the medical and physiotherapy practice, it is always a major challenge to determine the best treatment for those diseases that affect the quality of life. In neurological diseases, the gross and fine motor skills are frequently affected causing difficulties in the activities of daily living.

\section{ADL functions and motor skills}

The normally developing children are able to perform washing/bathing and dressing themselves independently by the age of 5-6. By the age of four, the children are able to eat with a fork and spoon without assistance. With regards to toileting, the age of 3 is taken as a milestone for being toilet trained. Transferring is completely developed by the age of 4 (Choo, 2014). The ADL functions require the well-developed fine motor skills that are not independent of gross motor functions.

Motor skills are essential for moving the body and parts of the body based on the activity of skeletal muscles as effectors. These motor skills are divided into gross and fine motor skills although they cannot be fully separated from each other. In life, individuals learn the gross motor skills first, and these skills become automatic as the years progress.

Gross motor skills help individuals to move and it involves using the large muscles of the body. These skills are vital for everyone. For example, the core muscles stabilize the trunk and this way it is possible to walk, run or to throw a ball.

Fine motor skills mean using the smaller muscles of the hands. It is required in everyday life in order to perform different kinds of tasks or to manipulate objects. Fine motor skills involve the task outcomes and the speed of the different kinds of task performances. It means the precise movement with the hands, which are required for writing using a pen and other similar everyday objects.

For a newborn baby to control body movements is difficult. The infants are unaware of the fact that they have hands. During life, they must learn hand-eye coordination, bilateral integration, hand dominance, hand division and how to manipulate objects. The proprioception as a sensory process is very important in the motor functions.

Hand-eye coordination means that if an individual switches off one of his organs that helps him to orient or to balance (for example, if one closes his eyes), then it does not cause any problems with coordination. 
Bilateral integration involves the two sides of the body, the movements of the upper and lower extremities, and reflex integration. The third one denotes that there are certain reflexes that work in a synergism. All of these three functions are based on the vestibular system.

Hand dominance signifies that all of the children use one of their hands more often. For example, a ball is always thrown with the same hand as is cutlery held with the same hand. Furthermore when writing, the pen or pencil is held in the preferred hand. Hence, the dominant hand is slightly more skilled than the other hand.

Hand division is somewhat similar to hand dominance. It refers to how the children divide the tasks between their two hands. If they only use one of their hands, then the other one can remain weaker and not so skilled.

Proprioception is also a very important function. There are numerous proprioceptors in our body which are mainly found in the joints, ligaments, and between the muscles' and the tendons' connection. On our hands, there are proprioceptors on the muscles called the lumbrical muscles. These muscles have many functions. They help to stabilize our fingers, they allow our fingers to do flexion and they play a role in the abduction and adduction movement. These proprioceptors help us to coordinate our movements and prevent falls on bumpy or moving surfaces.

If the children's development is physiological, then in the fourth month they can grasp their own hands. In the sixth month, they play with their big toe and in the seventh month, the radial grasp appears. In the eighth month, they start to use the inferior scissor grasp. In the ninth month, they can grasp objects with their thumb and index finger. By the end of the first year, they can use the pincer grasp, too. These timing points are not always the same, so if there is a slight difference in the development of the child, it is not a very big problem.

During the toddler stage, we can see that the children use one of their hands more frequently so the dexterity of the hands starts to emerge at this point in time. The preschool period is also a big challenge for children. This is because during this time, they have to learn how to tie their shoelaces, how to put on or take off their clothes, how to use cutlery and eat by themselves. There are good toys that can improve the children's fine motor skills such as building from blocks/cubes or playing with puzzles.

\section{Cerebral palsy}

Among the neurological disorders, one of the most common in childhood is cerebral palsy. Cerebral palsy (CP) is the most frequent neurological disorder in childhood with an occurrence of 2.11 per 1000 live births (Oskoui et al, 2013). The CP is defined by Bax and his coworkers $(2005$, p.2.) as "a group of disorders of the development of movement and posture, causing activity limitation, that are attributed to non-progressive disturbances that occurred in the developing fetal or infant brain. The motor disorders of cerebral palsy are often accompanied by disturbances of sensation, cognition, communication, perception, and/or behaviour, and/or by a seizure disorder."

Cerebral palsy affects almost the whole human organism. Children who suffer from this disease have abnormal muscle tone. Furthermore, their development is slower than a healthy child's. We can see asymmetry at how they use the two sides of the body. They have both fine and gross motor dysfunctions and they start to speak later than an average child. Besides, they also have difficulties with visual-hand control and their movements are not coordinated.

Himmelmann et al (2006) studied the motor functions and accompanying neurological disorders in children with cerebral palsy. 411 children diagnosed with $\mathrm{CP}$ aged from 4 to 8 years were involved in the study. They concluded that the motor functions and the type of CP together determine the total impairment load. 
Activity preferences and assessment of ADL functions in patients with cerebral palsy

Lemmons et al (2014) studied the activity preferences in hand-related ADL functions in different age groups. The movement components necessary for performance were also defined. It was found that the most preferred aims in the age group of 2.5-5 are related to dressing, and in the age group of 6-11 dressing and eating. However, in the age group of 1219 in addition to the previous aims mentioned, the preferred goal is typing on a keyboard and playing computer games.

James, Ziviani and Boyd (2013) reviewed 8 measures to reveal the impairments in ADL functions in children and adolescents. The Functional Independence Measure for Children (WeeFIM) is one of the recommended items.

The WeeFIM is suitable for measuring the ADL functions in the age range of 6 months to 21 years (Wong et al, 2002). In older patients, the Functional Independence Measure (FIM) is generally used in clinical practice.

These tests contain parameters about self-care, sphincter control, transfer, locomotion, communication and special cognition. If the patients can perform the task and they are independent 7 points are added, while 6 points are given if they need some kind of device to assist them in the different kinds of tasks. If the patients need supervision, then we give them 5 points. 4 points are given for the patients requiring minimal assistance and 3 points for patients who can do the tasks with moderate assistance. For maximum assistance 2 points are given, whereas 1 point is given for total assistance. In the WeeFIM the minimal total point is 18 , whereas the maximum is 126.

Both the FIM and the WeeFIM measure the same main parameters although in the FIM there are more little components below the main ones.

\section{Assessment of hand functions}

The Quality of Upper Extremity Skills Test (QUEST) is used mainly for those children who suffer from cerebral palsy. It can be used to measure dissociated movements at all the joints of the upper extremity, the quality of different kind of grasp, weight bearing at different positions, and protective extension (DeMatteo et al, 1992).

\section{Assessment of fine motor skills}

The revised version of Bruininks-Oseretsky Test of Motor Proficiency (BOT-2) (Bruininks and Bruininks, 2005) is frequently used by clinicians, physiotherapists and other professionals to measure the motor performance of the children with neurological disorders (Deitz, Katin and Kopp, 2007). The test contains 8 subtests including fine motor precision, fine motor integration, manual dexterity, bilateral coordination which are in the focus of our interest. It can be administered to individuals from 4 to 21 years of age.

The International Classification of Functioning, Disability and Health (ICF)

The International Classification of Functioning, Disability and Health (ICF) was provided by the World Health Organisation (WHO) in 2001 as a system which offers a good frame for diagnostic procedures, therapy and monitoring. The ICF gives a good possibility to describe the categories of individual functionality and disability. The version adapted to the children is also available: International Classification of Functioning, Disability and Health, Child and Youth Version, (ICF-CY). The ICF measures the functionality and disability in a multidimensional model: impairment of the body function, activity and participation are studied. Relevant subtests can be selected and combined for determination of the individual state. The use of ICF categories can complete the description of the body functions and can reveal finer details. Use the ICF/ICF-CY requires well-trained professionals. 


\section{Tools for improvement of fine motor skills}

The most frequently used methods are as follows: ergo (occupational) therapy, manual therapy, constraint induced movement therapy (CIMT), mirror therapy, proprioceptive neuromuscular facilitation (PNF), and piano therapy.

Ergo (or occupational) therapy is a method that helps patients to improve their everyday functions. With ergo therapeutic method, we can practice different kind of grasps and it helps us how to release subjects and how to make our movement more purposeful. More accurately, it involves using objects including plugs, cutlery and door handles (Paskaleva et al, 2010). This therapy is said to be effective with children with fine motor delays (Case-Smith, 2000). According to this method, we should use the child's sensory motor performance components in order to improve the functional performances. The therapists engage in playful tasks with the children thereby improving the youngsters' fine motor skills.

Manual therapy helps us to make our muscles more pliable and helps our movements. Manual therapy can incorporate stretching as well, which is also quite effective at making our muscles more flexible and helps us to warm up before the therapy. With stretching, muscle injuries can also be avoided.

Giuliani and his co-workers (2006) examined the efficiency of constraint induced movement therapy (CIMT) in stroke patients. They found a great improvement in arm motor functions in patients where they used the CIMT compared to the control group. According to the CIMT, the therapists tie the dexterous hand and this way the patient needs to use the clumsier hand. The method can be used in cerebral palsy also.

Mirror therapy is a special type of therapy. During this therapy, patients do tasks in front of a mirror. It is very useful for the patients because they are able to see what they are doing, and it is a type of visual feedback for the brain. The mirror is used as visual stimuli for the brain through moving a body part and watching it at the same time. Consequently, it is easier to learn movements using this therapy. Donghoon and his colleagues (2016) proved this method's efficiency with patients who had a stroke. They combined this method with motor tasks on the upper extremity.

Proprioceptive neuromuscular facilitation (PNF) is a special physiotherapeutic method, which has an effect on the different kind of loco motor system, especially in cerebral palsy (Levitt, 1966). This method works possible with the help of the different proprioceptors. These proprioceptors can be found in the joints, ligaments as well as between the muscles and tendons. PNF improves coordination, increases muscle strength, provides better stamina, makes the muscles more pliable, increases the range of movement, normalizes the rhythm and speed of the movement and the muscle tone itself. The patients should do different kinds of movement patterns cornerwise and have to overtake the resistance applied by the physiotherapist. This method is very useful because it can be used with numerous clinical aspects with excellent results.

Piano therapy is a new and special kind of therapeutic method. According to a study, the piano lesson's effectiveness was examined with a professional piano teacher with children who have cerebral palsy. The aim was to improve their fine motor skills. This therapy lasted for 18 months with every session being 35-40 minutes in duration. The movement and accuracy of the fingers as well as the speed of pressing the piano keys was examined. The music was a motivating factor for all the children as they could remain very enthusiastic during the therapy (Lampe et al, 2015).

\section{Study design for our studies}

The aim of our study is to reveal the ADL functions in the patients with cerebral palsy, to obtain information about the goal of rehabilitation preferred by the patients at a wide range of ages and to improve the fine motor skills in order to improve the hand-related ADL functions. 
It is a long term plan covering some semesters with more than one physiotherapy students. In every year 2-3 students write thesis work in this field which are not connected to each other. Our idea is to give a frame for these studies, so the students can work individually but along a common conception. In this case the results may be evaluated together and hopefully offer sufficient amount of data for evidence based conclusion.

The studies will be carried out in the Immanuel Home in Debrecen, where 82 patients ranging in age from 6-30 spend their daily hours. The Immanuel Home is an educational and social institution for disabled children and young adults. Approximately half of the participants suffer from cerebral palsy. In addition, there are children with genetic diseases, multiple handicapped children and children with diseases caused by infection or trauma. They are cared for by a team that includes an ergo therapist, a physiotherapist and a music conductor. The aim of the general physiotherapy is to maintain or develop the motor skills.

To measure the ADL functions, we will use the Functional Independence Measure (FIM) in older children and the WeeFIM in the younger patients. The FIM and WeeFIM tests will be completed by a question prepared by us: which task is the most crucial for the patients/parents to be improved?

These measurements will show us which functions need to be improved the most. According to the results, those children will be selected for further measurements and therapeutic interventions that have poor quality of these functions (the number of participants are estimated 20-30). For further measurements, we will use the test called QUEST (Quality of Upper Extremity Skills Test) and the Bruininks-Oseretsky Test of Motor Proficiency (BOT-2) to get more detailed information on the hand-related functions.

On the basis of the outcomes, a target group (at least 10 participants) will be established for the therapeutic intervention oriented to the improvement of hand-related ADL functions. Inclusion criteria will comprise impaired fine motor skills, informed consent from the patient (parents), proper communication skills, and regular attendance at the exercises.

The intervention will include the elements of the ergo therapy, manual therapy, proprioceptive neuromuscular facilitation (PNF), and piano therapy. The professional guide will be available for these methods.

The measurement of the ADL functions, the quality of the upper extremity skills and the Bruininks-Oseretsky Test of Motor Proficiency (BOT-2) will be performed once again at the end of the therapeutic programme.

Our short term plan for the next academic year is to perform the measurements according to the ADL function in the whole population attending the Immanuel Home, and to select the group for further investigation related to the hand function and fine motor skills. The therapeutic interventions will be performed after the screening of the needs and possibilities.

The results of our study are expected to be used routinely in the Immanuel Home, and hopefully, in a wider field in the care of disabled individuals.

\section{REFERENCES}

Bax, M., Goldstein, M., Rosenbaum, P., Leviton, A., Paneth, N., Dan, B., Jacobsson, B., \& Damanio, D. (2005). Proposed definition and classification of cerebral palsy, April 2005. Developmental Medicine and Child Neurology, 47, 571-576.

Bruininks, R. H., \& Bruininks, B. D. (2005). BOT-2, Bruininks-Oseretsky Test of Motor Proficiency Second Edition. Minneapolis, Minnesota: Pearson Assessments

Case-Smith, J. (2000). Effects of Occupational Therapy Services on Fine Motor and Functional Performance in Preschool Children. American Journal of Occupational Therapy, 54, 372-380. 
Choo, S. (2014). Assessment of activities of daily living in infants and children with developmental disabilities. The Singapore Family Physician, 40, 50-54

Deitz, J.C., Kartin, D., \& Kopp, K. (2007). Review of the Bruininks-Oseretsky Test of Motor Proficiency, Second Edition (BOT-2). Physical \& Occupational Therapy in Paediatrics, 27, 87-102.

DeMatteo, C., Law, M., Russell, D., Pollock, N., Rosenbaum, P., \& Walter, S. (1992). QUEST: Quality of Upper Extremity Skills Test. Hamilton, ON: McMaster University, CanChild Centre for Childhood Disability Research.

Donghoon, K., Kyoungbo, L., Kyunghoon, K., Sukmin, L., \& Youlim, K. (2016). Effects of mirror therapy combined with motor tasks on upper extremity function and activities daily living of stroke patients. Journal of Physical Therapy Science, 28, 483-487.

Himmelmann, K., Beckung, E., Hagberg, G., \& Uvebrant, P. (2006). Gross and fine motor function and accompanying impairments in cerebral palsy. Developmental Medicine and Child Neurology, 48, 417-423.

James, S., Ziviani, J., \& Boyd, R. (2014). A systematic review of activities of daily living measures for children and adolescents with cerebral palsy. Developmental Medicine and Child Neurology, 56, 233-244.

Lampe, R., Thienel, A., Mitternacht, J., Blumenstein, T., Turova, V., \& Alves-Pinto, A. (2015): Piano training in youths with hand motor impairments after damage to the developing brain. Neuropsychiatric Disease and Treatment, 11, 1929-1938.

Lemmens, R.J., Janssen-Potten, Y.J., Timmermans, A.A., Defesche, A., Smeets, R.J., \& Seelen, H.A. (2014). Arm hand skilled performance in cerebral palsy: activity preferences and their movement components. BioMed Central Neurology, 19, 14:52.

Levitt S. (1966). Proprioceptive neuromuscular facilitation techniques in cerebral palsy. Physiotherapy, 52, 46-51.

Oskoui, M., Coutinho, F., Dykeman, J., Jetté, N., \& Pringsheim, T.A. (2013). An update on the prevalence of cerebral palsy: a systematic review and meta-analysis. Developmental Medicine and Child Neurology, 55, 509-19.

Bax M, Goldstein M, Rosenbaum P, Leviton A, Paneth N, Dan B,

Jacobsson B, Damanio D.

Paskaleva, R., Mihaylova, R., Mollova, K., \& Petrova, M. (2010). Features of kinesitherapy and ergotherapy for children with cerebral damage. Trakia Journal of Sciences, 8, 346-348.

Wolf, S.L., Winstein, C.J., Miller, J.P., Taub, E., Uswatte, G., Morris, D., Giuliani, C., Light, K.E., Nichols-Larsen, D., \& EXCITE Investigators. (2006). Effect of Constraint-Induced Movement Therapy on Upper Extremity Function 3 to 9 Months After Stroke. Journal of the American Medical Association, 296, 2095-2104.

Wong, V., Wong, S., Chan, K., Wong, V. (2002). Functional Independence Measure (WeeFIM) for Chinese children: Hong Kong Cohort. Pediatrics, 109, E36. 


\title{
LEARNING DIFFICULTIES OF CHILDREN WITH EMIGRANT PARENTS ${ }^{8}$
}

$\begin{array}{cc}\text { Authors: } & \text { Lectors: } \\ \text { Cristina Catalano } & \text { Horatiu Catalano } \\ \text { Babes Bolyai University (Cluj Napoca, } & \text { Babes Bolyai University (Cluj Napoca, } \\ \text { Romania) } & \text { Romania) } \\ & \text { Magdolna Nemes } \\ & \text { Babes Bolyai University (Cluj Napoca, } \\ & \text { Romania) } \\ \text { E-mail address of the first author: } & \text { Veronika Schéder } \\ \text { cris25_catalano@yahoo.com } & \text { University of Debrecen } \\ & \text { Katalin Mezö }\end{array}$

Cristina Catalano (2017): Learning difficulties of children with emigrant parents. Különleges Bánásmód, III. évf. 2017/1. szám, 87-93. DOI 10.18458/KB.2017.1.87

\begin{abstract}
In the beginning of the 21st century a lot of Romanian parents leave their country to work abroad. While they are away grandparents or other relatives look after their children. The pranets and their children keep in touch via Skype, Viber or other technology that allows verbal communication only. It has turned out that the parents' leaving impacts on children as they have a lot of psychological problems. Moreover, they have differents learning difficulties and have behavioral problems at school. The solution to solve the problem could be special methods for children with learning difficulties.
\end{abstract}

Keywords: a kulcsszavak angol nyelvü fordítása

Disciplines: a diszciplinák angol nyelvü fordítása

\section{Absztrakt}

A 21. század elején sok román szülő hátrahagyja gyermekét/gyermekeit, külföldön keres megélhetést. A szülők távollétében a gyerekekt a nagyszülők vagy más rokonok nevelik. A szülők és gyermekeik Skype-on, Viberen tartják egymással a kapcsolatot, ám ez a csatorna csak a verbális kommunikációt teszi lehetővé. A gyerekeket megviseli a szülök tartós hiánya, különféle pszchológiai problémák lépnek fel náluk. A gyerekek körében tanulási

\footnotetext{
${ }^{8}$ The editorial board does not take any responsibilty for the English of the papers. Indeed, we made some slight changes but wanted to keep the style of the authors.
} 
nehézségeket is megfigyeltek. A helyzet megoldására a felkészült tanárok és a megfelelő módszerek adhatják meg a választ.

Kulcsszavak: kulcsszó1, kulcsszó2, kulcsszó3, kulcsszó4

Diszciplína: pl. gyógypedagógia, pszichológia, jogtudomány stb.

\section{THE EMIGRATION OF PEOPLE FROM ROMANIA- A FAMILY PROBLEM}

The Romanians' 'gold rush' in the $21^{\text {st }}$ century is the exodus of unemployed people. They go abroad to become 'the slaves of the West'. The statistics show that more and more parents abandon their families and children to leave and work abroad, i.e. in Spain, Italy, Greece, Germany and England. Even if they can't get a job in these countries (or even if they can), most people prefer to stay abroad because they say that they wouldn't find a job in Romania. This phenomenon is common because nowadays many foreign companies try to employ Romanian people, and they can't get enough workers. The most important problem is represented by these parents' children who stay at home with or without any relatives. The phenomenon of the 'orphan' children with parents who are still alive is one of the most unexpected and dramatic that the Romanian family is now experiencing. For this reason, these children have countless absences from school, they are inclined to aggressiveness, committing crimes, taking drugs, tobacco, and alcohol. $85 \%$ of the children who go to a psychiatrist have at least one parent living abroad - the parents prefer paying for the treatments than coming back and staying with their children. Unfortunately, school has not solved the problem of inequality either, as failure is often linked to the social origin and, more recently, to the emigration phenomenon. The students who have learning difficulties are generally those who come from poor or modest families. It is difficult for the parents to hep their children learn because of the distance between them - even if the parents are willing to help, the distance is too significant. It encourages parents to 'educate through the telephone, or other technology'. This can be considered as a way of living because they can communicate very easily via Skype, Viber or Facebook. This communication is limited because it only allows verbal communacation - feelings or other direct contact cannot be put across.

In the short term, the parents' leaving impacts on a child's life. A child can show signs of verbal or physical aggressiveness, marginalization, anxiety, low marks, school skipping and even school abandoning. In the long run, this generation of children are deprived of their parents' love and of the family harmony. Many of them may experience difficulties when they are older. Also, there is the possibility that some of them will even become criminals. As a result the aggressiveness of many children belonging to the 'home alone' generation, their refusal to accept the fact that they have problems, and the pain caused by their parents' absence and leads them to become part of a generation of socially non-integrated adults in the future. The child that grows up without parents, or only with one of them, will become an adult who cannot understand the meaning of marriage and who does not trust the institution of marriage and people in general. More and more young people that go abroad to work in order to provide themselves a better life return home with serious psychological disorders.

The long period of time spent away from the family can create a crisis situation for the migrant person and their family. The negative effects can be noticed both at the level of the individual as a citizen abroad and at the family level. However, lots of people try to analyse things from another viewpoint. It is a nice thing to have the courage to enter another work market, to learn another language, to have access to another culture, to another system of values, to begin to assimilate into a society that is different from one's, but the possible risks associated to oneself, as an individual, and to one's social environment must be kept to a 
minimum. It is about the social relationships that one has until the moment of departing. However, these things are not always taken into account.

\section{Typology of the Learning Difficulties}

During school years, a child can show signs of poor language development. The most common of these are as follows:

- Dyslalia, which is a deviation from the usual pronunciation; the impossibility to make sounds or their omission; the replacement of some sounds with others; sound conversions;

- Stuttering is a more serious disorder that occurs more frequently among boys. There are three forms: chronic stammering - interruption of the fluency of speech due to extension or repetition of sounds and syllables; fluff note, this occurs when there is a blockage at the first word in the sentence due to an articulated, long-form spasm and mixed form;

- Delays in the overall development of the speech are met at those children who fail to attain the average level of speech as children of the same age. Such phenomenon is materialized into a poor vocabulary and low possibilities in the formulation of sentences and phrases. Delays in speech development may include both noise issues, but also lexical and grammatical ones.

- Elective dumbness (volunteer) - occurs frequently among hypersensitive children through a temporary, partial or total dumbness. Children refuse to communicate over a certain period of time with some people, and after a period of time, this can be a big problem, refusing to speak.

- Dyslexia and dysgraphia- refers to the inability to learn reading and writing. School children with such a disorder make constant and repeated confusion between letters and their grapheme; inversions, additions, omissions of letters and graphemes, omissions, inversions, additions of words and even sentences. A child with such a deficiency has difficulties communicating at the highest level of language. This feature prevents assimilation, internal storage and automatism of spelling rules. Because of the misunderstanding of readings and even their own hand writing, verbal language is not often expressed as it should be.

Infidelity of speech - a dysfunction caused by many factors. It is the disparity between the content and meaning.

Fantasy Play - is the child's ability to transform the real into surreal. It can negatively influence the learning process because the child's fantasy starts with physical or emotional needs.

All these coordinate the mental life of pupils, if acting together, decreasing the intellectual potential of the pupil and leading gradually to installment of mental deficiency in children. It is a psychological factor that causes school failure, inducing a decrease or a loss of cognitive functions. General intellectual activity is measured by a coefficient of intelligence (Q.I) by evaluating the results achieved in applying a standardized intelligence test administered individually. Following the research of A. Binet and Th. Simon (1904) "metric staircase" of intelligence has been developed and constantly updated. It specifics that there is a correlation between the age of the children and their mental age by establishing more or less deviations (degree of deviation) than the standard average of the age.

Emotionally speaking, referring to states, feelings and affective-attitudinal behavior of children with emotional disturbances, we intend to point out the following:

a) Shyness / Bashfulness - is commonly defined as a form of behavior characterized by lack of security, self-reliance, lack of boldness, fear, hesitation, defense reaction.

b) Anxiety - is resulting from a threat of self-respect, current or anticipated, based on underestimation of "inner-self ", lower self-evaluation; the most important feature of the anxious child is that she/he lives any situation that he/she is involved in as dangerous and 
never ceases to anticipate failure for each of their own activities no matter where this takes place.

c) Fear of school - is the most natural and common form of fear of separation. Once the first few months of transition to school attendance have passed and the fear of separation has not decreased but, on the contrary, intensifies and takes the form of having attacks of panic, then it is a symbolic type of fear called school phobia. Often, the cause of it is from a strong parent-child relationship, that it is more intense for mother than the child. The school begins to weaken the relationship of maternal dependency of the child, which plays an important role in their development up until the school age - but if maintained would have a negative influence on a child's future development. The child overestimates his/her skills, potential, performance, and the school threatens to scatter this belief, which is why she/he is heading towards preserving a situation which amplifies the image of their " inner-self " in a surreal and only apparently stimulating way.

d) Nervousness/Impatience - is often the way a child responds to the conditions and realities of life including school and family environments. The state of nervousness can be a short lined, without affecting the fundamental balance of the person. The environment can also be an influencing factor to a child's level of nervousness/impatience. Forms of expressions that shape the behavioral profile of the impatient and nervous child are varied: irritability, anger, hostility, depression, vulnerability, disturbances in food and sleep regime, psycho-motor instability, hysterical crises.

Children encounter motivation at difficulties like:

- The absence of intention to learn, lack of desire to achieve a specific purpose, which is either self-determined, or following explicit instructions from someone else.

- Inappropriate/ unrealistic expectation, that does not take into account the specific context in which the action is taking place.

- Lack of stimulation/ motivation - which may be due to objective or subjective factors, and which may cause many different effects regarding school activity.

- Lack of cognitive abilities (knowledge, abilities, skills, etc.) - leads to awareness of which often leads to lack of motivation, lack of care and participation, escape from the tasks/ responsibilities and, of course, to the appearance of learning difficulties and school failure.

The volitional act will be affected in the following ways:

- Negativism - is children's resistance to external or internal applications, which may take a passive position in which the child presents resistance to all requests or an active form that the opposite of the demands addressed to child. We may also include forms of stubbornness, interposing, spirit of resistance.

- Lack of persistence - is characterized by the inability of children to fight against the hardships that are in the way of achieving a goal or desire; or to do only what is pleasant, interesting from their point of view.

Studying the children's personality, involves getting to know and evaluate them in the correct manner. From the perspective of the school - the educational knowledge that is required. it needs to include formal qualities, dynamical - energetic (temper), socio-moral, character and attitudinal features. Immaturity of the character is derived from wrong doings in the educational process taking place in the family. Children can show a false understanding of moral concepts, appreciation of other people, facts and actions, or their own conduct, a total disagreement between moral knowledge and facts, views and conduct. Character Disorders express irregular development of personality, including negative social experiences in family and school life. 
Temper is a dynamic - energetic side of personality and is being expressed by the peculiarities of behavior (mobility and speech). Both emotiveness and activity are closely related to the "force" and "balance" of the nerve processes, characteristics which are obvious and relatively easy to be diagnosed. Behavioral disorders frequently occur in children who are excitable, nervous, with poor development and a weak control of the cortex of sub-cortical regions. For am adult (teacher or parent) it is important to determine whether a child is active or emotional. Because if a child shows they are inactive, he/she could be slow, lazy, and have no initiatives - factors that are described in the character disorders section. On the other hand, if the child has intense emotional reactions, they would be very involved in everything they do.

Another problem would be the negative attitudes towards education such as a lack of desire to fulfill the learning demands of the teachers, the lack of involvement, escape tasks, absences, resistance to the requests formulated by parents and teachers, violation of rules imposed by school and during classes, formal attending of teaching activities, without actual involvement/strive to understand explanations and content taught.

\section{The importance of teachers and schools in childrens' lives}

The only solution for solving these children's problems is to adapt the schools routine and educate teachers on children's learning difficulties. In these cases, the main requirement is organizing and conducting the learning process and individual learning strategies and methods for children with learning difficulties. In this respect, it is necessary for teachers to be knowledgeable of a range of teaching strategies - helping them to identify and support learning difficulties in the classroom. In our opinion, regardless of the school level, the fundamental requirements that teachers have to bear in mind are the following:

- to know the cross learning difficulties of each child, and also the specific learning difficulties in certain curricular areas and disciplines of study;

- to adapt the procedural and methodological resources to the specific learning difficulties in order to reduce non-effective learning and the appearance of the game of school;

- to purchase or create teaching aids when needed and use them especially to facilitate the learning process;

- to ensure every class has the necessary time to assess the effectiveness of the formative way of learning and teaching, thus supporting the efforts of children with learning difficulties and to adjust the conditions of learning (evaluation itself becomes a tool /aid for training).

Building a secure learning environment, appropriate and stimulating for all children including those who benefit from additional and more specialized support. This is one of the priorities when addressing the problems of children with learning difficulties. A secure environment provides children with learning difficulties psychological, allowing them to express themselves and build relationships.

This problem can't be solved only by the teachers. It is necessary for both sides to accept the help of some specialists, such as;

the psychological and pedagogical advisor (who deals with the general and specific learning problems at the individual and group levels) has in mind, in reference to the intervention issues, the following: the construction and the functionality of the general learning instruments (general and specific abilities, skills and capabilities) which focus on the attention, social and emotional inter-relationships, learning rhythm (slow or inappropriate), the use and the exercise of the logical and mathematical structures (argumentations, algorithms, the operationality of thinking), decision making, the conflict management, and the complex process of communication. and etc. The advisor's activities are meant for the students, teachers and parents, as well as for the necessary links between these actors of the education, in order to provide efficiency to the didactic process - both at the individual level 
and at the level of the class group and of the school/institution; the speech therapist deals with the detection, the complex examination and the personalized intervention in regards to the language difficulties and disorders ; the support teacher, the itinerant teacher and other didactic people, intervene to solve learning problems by various practical means integrating the children with special requirements or to support the normal school in fulfilling the tasks of the inclusive school (for all the children). Also, when it comes to directly intervening in the didactic activity, we have to think about the type of intervention that can support the didactic process and its protagonists. In the literature the things are not completely clarified (as the terminological delimitation of the learning difficulties is not either) - one speaks about new roles that the didactic staff can play in order to become: a resource teacher, a tutor, an advisory teacher, an itinerant teacher or a support teacher (amongst all these new kinds of teachers there is a link determined by the need of an intervention - in the classroom and outside the classroom - for solving the learning problems.

The parents notice some cognitive behaviours of their children from early ages and take their children to a specialist. They cooperate with all the people involved in the intervention, with an aim to recover, to compensate or to correct the learning difficulties.

An important way for solving the problems is the Personalized Intervention Plan, which teachers can make together with the other implicated persons. In this they must find out the right learning difficulty/difficulties and the ways that this/these can be deminished.

\section{CONCLUSIONS}

Although we cannot speak about an alarming number of children with school problems, there are many cases of children with poorer results, more absences, a lower grade for the behaviour, or simply cases of children who have no pleasure in attending school. For the children whose parents have left to work abroad, school represents an important factor of stress. As an operational method for acting, the establishment of the differential diagnosis is very important. The child with learning difficulties may be recuperated if they attend personalised intervention programmes which carefully include; objectives, proper recuperation activities, specific methods and means, and the duration of each activity is considered as well as the forms of the periodical and final evaluations.

\section{REFERENCES}

Catalano. H. (2008). Migraţia - o nouă cauză a dificultăţilor de învăţare în şcoala contemporană. în Revista „Educaţia 21” editată de Institutul de Pregătire Didactică a Universităţii Babeş-Bolyai Cluj-Napoca.

Catalano. H. (2009). Dificultăţile de învăţare transversale. Program de intervenţie educaţională pentru elevii cu părinţi emigranţi. Editura Paralela 45. Piteşti.

Catalano. H. (2009). Fenomenul migraţiei. Consecinţe socio-educaţionale. în Instrucţie şi educaţie în şcoala contemporană. Editura EUROTUR-13-2000. Bucureşti.

Catalano. H. (2009). Abordarea psihopedagogică a dificultăţilor de învăţare. Implicaţii la nivelul diferitelor componente ale personalităţii. în Revista „Educaţia 21”. editată de Institutul de Pregătire Didactică a Universităţii Babeş-Bolyai Cluj-Napoca.

Catalano. H. (2013). Programul de intervenţie educaţională ca instrument al adaptării curriculare. în Abordări curriculare. Aplicaţii în învăţămăntul incluziv. Editura Eikon. Cluj-Napoca.

Cerghit. I. (1983). Perfecţionarea lecţiei în şcoala modernă. Editura Didactică şi Pedagogică. Bucureşti. 
Dragomirescu. V. (1976). Psihosociologia comportamentului deviant. Editura Ştiinţifică şi Enciclopedică. Bucureşti.

Gherguţ. A. (2005). Sinteze de psihopedagogie specială. Editura Polirom. Iaşi.

Ieniştea. O. (1982). Dificultăţi la învăţătură. Editura Medicală. Bucureşti.

Kelemen. G. (2007). Copilul cu dificultăţi de învăţare. Editura Universităţii „Aurel Vlaicu”. Arad.

Neacşu. I. (1978). Motivaţie şi învăţare. Studiu asupra motivelor învăţării şcolare în ciclul gimnazial. Editura Didactică şi Pedagogică. Bucureşti.

Păunescu. C. (1977). Deficienţa mintală şi organizarea personalităţii. Editura Didactică şi Pedagogică. Bucureşti.

Vrăşmaş. E.A. (2007). Dificultăţile de învăţare în şcoală. Editura V\&I Integral. Bucureşti.

Ungureanu. D. (1995). Copiii cu dificultăţi de învăţare. Editura Didactică şi Pedagogică. Bucureşti. 


\section{BOOK REVIEWS}




\section{BOOK REVIEW ${ }^{9}$}

Authors:

Adrienn Oravecz

Eszterházy Károly University

E-mail address of the first author:

ora_adri@msn.com
Lectors:

Éva Feketéné Szabó

College of Pető András

Tünde Rózsahegyi

University of Volverhampton

Veronika Schéder

University of Debrecen

Katalin Mező

University of Debrecen

Oravecz, Adrienn (2017): Book Review. Különleges Bánásmód, III. évf. 2017/1. szám, 97-99. DOI 10.18458/KB.2017.1.97

\section{Bibliography of the subject of this recension:}

Strzalkowski, Ralph (2013): Never, never quit My Conductive Education. Conductive Education. England: Press Birmingham.

Keywords: conductive education, cerebral palsy

Disciplines: conductive pedagogy, special needs education

I would like to recommend this book for professionals who works with children with special education needs especially, to conductors and parents who have children with cerebral palsy. I hope both conductors and parents will find Ralph's story motivating and encouraging to continue their long and hard journey to make their children mobile and independent as much as possible.

The writer of the book Ralph Stralkowski who was born in 1979 in Warsaw, Poland with cerebral palsy. His parents became the pioneers of inclusive education in Poland. Ralph was a weekly boarder of The Petö Institute from 1986 to 1990. Later he got his postgraduate law degree in Poland then he went to a law scholarship to the University of Florida and now he has his own law practise in Florida. In 2011 he started to write his regular blog and this book is the collection of his 53 postings. In 2013 in Munich, Ralph was a Keynote Speaker of $8^{\text {th }}$ World Conductive Education Congress.

Supplementary book was born because the writer highlights conductive education form a very unique perspective through his own experience. Nobody has done this before. The 59 postings which were selected into the book deals with two major topic. First, his memories

\footnotetext{
${ }^{9}$ The editorial board does not take any responsibilty for the English of the papers. Indeed, we made some slight changes but wanted to keep the style of the authors.
} 
from childhood while he was a weekly boarder of the Petö Institute and then the present situation of Conductive Education in the United States.

The book begins with the author's introduction. In the introductory part Ralph talks about he never intended to write a book, but finally he agreed to bring his postings to a larger audience. As he says the value of this postings are "what he has already accomplished." Those who has not got such an irreversible condition like cerebral palsy cannot imagine how challenging life can be especially if you have to be in a wheelchair every day. This condition requires creativity and highly developed problem-solving skills from the patient, not to mention the daily hard work so as to maintain physical strength and well-being. These elements are necessary for living a good quality of life with CP. In the other part of the introduction the author talks about how difficult was for him to find the proper title. In my opinion he could finally come up with a very expressive title. The title express not just the writer's attitude itself, but also fits to his parents and conductors way of seeing things. He could not have found a better title for the book.

Let me continue my review with this never, never quit attitude from the parents 'side. He mentions several therapies including The Bobath, Japanese massage and many more because his parents never wanted him to lie idle. His mother even became certified in the Doman method just to make him better. He talks about the sacrifices of his parents made for him. His mother quitted her job and his dad took extra shifts in order to lets him have everything from normal education to the best rehabilitation methods. During the Communist government his parents fought against a whole system in which disability was seen as scarlet letter. "Nothing was really wheelchair-accessible and for years and years they would carry me up to stairs to class every day- at first unofficially under an agreement with the teachers to avoid problems. But I grew bigger and heavier and they got weaker and weaker. Their backs suffered, their health declined, but there was one goal for me to get an education."(Strzalkowski, 2013, p. 36). His gratitude to his parents and their endless love and believe in him belongs to one of the most touching episodes of the book.

This never, never quit attitude is true for conductors as well. Ralph describes The Petö Institute as a homely place where he was loved by the conductors. He shares a very vivid memory with a conductor nick named as "Crazy Marika" but not in a negative sense, because he enjoyed her company so much because of her good sense of humour. Yes, it is essential to fill the strict frame of the conductive complex program with jokes and other enjoyable activities. My conductor Csilla Bédy has a great sense of humour too. She can imitate me very well, so when I did something wrong she was my funny mirror and I had always roared with laughter, this pedagogical technique helped me to correct the position by myself. Conductors are very creative too. The writer also mentioned this characteristics of them. "They often modify routines and exercises because they know what works and what doesn't and they learn to adopt."(Strzalkowski, 2013, p.15). Csilla often modified the routines with adding some dancing, for example Zumba, or step-aerobic to it because, she knew that our group would enjoy it very much. In my opinion what makes The Petö Method special it really teaches step by step how to stand up to that person who was judged incapable of doing this. Furthermore, it gives a key for the motor-disabled persons how they can live a normal life in spite of their disability. As I experienced the key elements of success are the following: First, the tasks of conductive program can be easily convert and used in a real life situation. Second, you learn to adopt this" You can do it, do not give up!" behaviour from your conductor. This optimistic and supportive attitude helps me when my able-bodied peers try to discourage me.

Finally, cerebral palsy affects different areas of the brain therefore it makes very complicated to measure the progress and its validity by standardised tests. As a researcher I see one solution that could work in the future: long-term observation. I completely agree with Ralph if Conductive Education wants to prove that it is effective they should seek and show 
their former students who became successful despite of their cerebral palsy. Here is one of the success stories of the Petö Method I hope you will find his story interesting because he is a truly remarkable individual as Andrew Sutton wrote it in the foreword of the book. 


\section{INTERNATIONALISING CONDUCTIVE EDUCATION REPORTS FROM RECENT ADVANCES IN CONDUCTIVE EDUCATION ${ }^{10}$}

\author{
Authors: \\ Adrienn Oravecz \\ Eszterházy Károly University
}

E-mail address of the first author:

ora_adri@msn.com

\author{
Lectors:
}

\author{
Tünde Rózsahegyi \\ University of Wolverhampton \\ Magdolna Estefánné Varga \\ Eszterházy Károly University \\ Veronika Schéder \\ University of Debrecen \\ Katalin Mező \\ University of Debrecen
}

Oravecz, Adrienn (2017): Internationalising conductive education: reports from recent advances in conductive education. Különleges Bánásmód, III. évf. 2017/1. szám, 101-103. DOI 10.18458/KB.2017.1.101

Bibliography of the subject of this recension:

Sutton, Andrew and Maguire, Gillian (2010): Internationalising conductive education. Birmingham (England): Conductive Education Press. ISBN 978-0-9569948-1-3

Keywords: Conductive Education, Different Social Context, Therapies for cerebral palsy

Disciplines: Special Education, Conductive Education

The editors of the book are Andrew Sutton and Gillian Maguire. Andrew Sutton has been involved with Conductive Education since 1979. He contributed to the political movement to introduce Conductive Education into the UK. Then in 1986, helped to found Foundation for Conductive Education, directing it till he retired in 2004. Before that his personal collection of written materials about Conductive Education formed the basis of the National Library of Conductive Education in Birmingham, England, and he created the journal Recent Advances in Conductive Education. Since retirement he also helped to create Conductive Education Press, and blogs at www.conductive.world.info.which collects up to date information about Conductive Education worldwide.

Gillian Maguire is The Librarian of the National Library of Conductive Education from 1991. The basis of the library was Andrew Sutton's personal collection but over the years it has grown over 6000 items. The library tries to reflect on the spread and development of

\footnotetext{
${ }^{10}$ The editorial board does not take any responsibilty for the English of the papers. Indeed, we made some slight changes but wanted to keep the style of the authors.
} 
Conductive Education. The goal of the Conductive Education Press is to stimulate new publications in the field of Conductive Education where Gillian works as the co-editor. In 2008 she started a blog Conductive Education Information to inform those interested in CE about new publications, articles internet sites, new centres etc. and offering an enquiry service. In 2010 she established the Virtual Catalogue of CE materials which is available on http://www.e-conduction.org/virtual-library-catalogue/. In 2011 she created and still maintain the World Map of Where Conductors Work available on http://www.e-conduction.org/whereconductors-work/. Both of them received the Honorary Conductor Award, Andrew Sutton in 1990 and Gillian Maguire in 2010.

In introductory part written by the editors the reader was informed about a journal Recent Advances in Conductive Education which appeared twice a year from 2001 to 2009. It was not a proper journal in the sense of collecting pre-reviewed articles written and accepted by an academic comitee. The journal was ended because those who were involved in Conductive Education they had no capacity to do this further while they had to solve more pressing things in their daily work. The other reason was there was no and still has not got a coherent academic wing in this field. It is a sorrowful event that since the death of Mária Hári has no academic journal of the Petö Institute. There was the Conductive Education Papers in which the staff of the institute published in a foreign language. Now they have an online journal but not a pre-reviewed one and the articles written exclusively in Hungarian called Science and Profession. In my opinion this good but if they want a spirited conversation and stronger cooperation with foreign Conductive Education Centres in the near future they really should issue materials in English as well which is appropriate to the academic publishing standards. What makes this book unique it gives a written record of the internationalising process of Conductive Education, there is no other accessible documentation about how did it happened outside Hungary. Fourteen articles were selected into the book. Authors were asked to give a brief update of where things stand in 2010. I would be very curious about what has happened since 2010 up to the present day.

The first article described how Conductive Education was brought to Sheffield. In 2010 the Places School has a greater financial viability a step nearer the mainstream of conductive education and a small measured of increased choice for parents. The project could not accomplish the transition to create an alternative for young adults. This is one of the recurrent topics of Conductive Education. I said it previously that it would be very urgent to support young adults because with ageing their condition decreasing day by day. If they are not healthy enough they will not be able to work and earn money to finance their own cost of living. This is a vicious circle and constant dependence from society and family is very frustrating.

The second article had not got a happy ending because it depicted a long process how Conductive Education was introduced in California but the service was finished in November of 2008.

The third article informed the reader about a successful adaptation of Conductive Education in Israel. In 2010 Andrew Sutton wrote the following: "The base establishment by Tsad Kadima's pioneers had provided firm footing for extensive subsequent development" (Sutton and Maguire p.49 )The process of development was collected into a book which was introduced at $9^{\text {th }}$ World Congress on Conductive Education in December of 2016.

The forth article presents the situation in Norway. Norsk Forum for Konduktiv Pedagogik is a parent-owned and parent-run organisation in Hamar. In October 2004 another was opened offering services for adults in the town Stavanger. The centre provides short-term courses and weekly sessions for Prkinson's disease, young adults with cerebral palsy and children with dyspraxia. The writer of the articles listed the challenges she had to face with as a conductor. First, little or nothing was known in relation to her work with adults. Second, explanation of 
her profession was problematic too so finally she came up with the idea she is a special pedagogue in the field of motor disorders. In 2010 Keri Hapnes the author concluded the process in the following way: The job of the conductor had become more recognised and more respected although the change of the professional title was necessary using the term rehabilitation pedagogue instead.

The last article I would like to mention is the Mexican model. What I really liked that they used art to advertise Conductive Education. A talented boy called Ekiwah Adler was mentioned who wrote poetry and plays which were presented in workshops. Other children were gifted in painting so they organised exhibitions for them. The experience of these children were filmed in 2003. The film got the Ariel prize a national prize for the best documentary of the year. From 2008 to 2010 they had enough resource to hire some experienced conductor from the Pető Institute. As a next step they would like to provide formal training and constitute a training centre for those who would like to be a conductor. Discussions started with the Pető András College.

This book is recommended who would like to know more about Conductive Education. I wish you pleasant reading! 


\section{GENESIS $^{11}$}

\section{Authors:}

Adrienn Oravecz

Eszterházy Károly University

E-mail address of the first author:

ora_adri@msn.com

\section{Lectors:}

Éva Feketéné Szabó

College of Pető András

Tünde Rózsahegyi

University of Wolverhampton

Veronika Schéder

University of Debrecen

Katalin Mező

University of Debrecen

Oravecz, Adrienn (2017): Genesis Különleges Bánásmód, III. évf. 2017/1. szám, 105-107. DOI 10.18458/KB.2017.1.105

Bibliography of the subject of this recension:

Schenker, Rony (2016): Genesis. Birmingham (England): Conductive Education Press. ISBN 978-1-36-679717-9

Keywords: Conductive Education, Special Education, Children and adults with cerebral palsy

Disciplines: Special Education

The foreword is written by Norman Perrin a dedicated parent who became Honorary Conductor in 2013. The designation of Honorary Conductors Award is to appreciate the work of non-conductors in the field who deserve a wider and more formal recognition. Contribution to the development of Conductive Education is considered by the IPA Nominating Committee as one of the criteria while the final decision is decided by the authorized Senate of Andras Petö Institute of Conductive Education and College for Conductor Training. The celebration of Honorary Conductors happens every 3 years when the World Congress on Conductive Education takes place.

The editor of the book is Rony Schenker who also had received this honourable title in 2007. She is originally a qualified occupational therapist, but she was one of the first health professionals who recognised early that something great was happening in Hungary during the time when the country was behind the Iron Curtain. She participated in the first international course organised by the Petö Institute. When Tsad Kadima the Israel Model of

\footnotetext{
${ }^{11}$ The editorial board does not take any responsibilty for the English of the papers. Indeed, we made some slight changes but wanted to keep the style of the authors.
} 
Conductive Education came into exist she served as a Professional Director of the Association. Recently, she has been serving as the Academic Director of the Association and the head of the Centre for the Israeli Centre of Conductive Education and Cerebral Palsy Studies.

The topic of the book is how Conductive Education was brought to Israel. Qualitative research was used to collect data for this book. Twelve persons were interviewed including family members and professionals. Professor Asher Shkedi from Hebrew University's School of Education was a key figure in the research process because during his course final year conductor students became familiar with the paradigm of qualitative research methodology. The material of the interviews were analysed with the help of the conductor students as their final project in 2015.

The topic is relevant because recently a very limited number of publication is available on Conductive Education in English. What makes this book even more special is that it gives a proper documentation on how CE was adopted successfully outside Hungary in a very enjoyable narrative style. Tsad Kadima like a seed it was planted and grew year by year and became a "beautiful tree" which has its own value, but could also preserve the basic essence of Conductive Education practised in Hungary.

The book is divided into three major parts. The first part contains the introduction, Tsad Kadima and the Conductive Education approach, and the interviews with the founding generation. The second part is divided into twelve subchapters including the first steps, impressions about Hungary and The Petö Institute, early frameworks of activity in Israel in the spirit of Conductive Education, then differences between Conductive Education at Tsad Kadima and at the Petö Institute and finally facing forward to the future. The final part contains only two subchapter: Telling our story and Envoi.

After the structure was drafted let me talk about the major topics discussed in the book. Similarly to other foreign countries the story of Tsad Kadima began with the film titled Standing up for Joe too. Thanks to this film the Hungarian Conductive Education approach was the full glare of publicity therefore more and more people came to The Petö Institute where it was practised in order to get to know more about it. Tsad Kadima the Israeli Association for Conductive Education was established in 1987. Today, the conductor specialism can be acquired at the Centre for Conductive Education and Cerebral Palsy Studies that is run in conjunction with the Levinsky College of Education in Tel-Aviv and the András Pető College in Budapest. Since the founding of the Association more than eighty Israeli conductors have been trained which is the second largest number after Hungary. Israeli conductors work in a trans-disciplinary model with other health professionals such as occupational therapists. Cerebral Palsy is a severe condition which affecting people through life therefore Tsad Kadima offers various services from infancy to adulthood. At the beginning it was just a small organisation but up to the present day it has become a dominant force of the educational- rehabilitative system of Israel. The other important role of the Association is to give a platform for professional discourse: organising international conferences, seminars, researches.

In chapter 4 titled Beginning the journey parents talked about the shock when the doctor diagnosed their child with $\mathrm{CP}$ and also the different attitudes they experienced within the family. For example a grandmother always said to his grandson Matan until she passed away: "We should only see him walking on his own two feet." (Schenker, 2016.21.p.) Because she could not come to terms with the situation. Yes, this is true a disabled person changes everything even the relationships of family members with each other. Udi Lion a father mentioned the tendency for fathers to run away and high percentage of divorce. In my opinion for a man it is more difficult to accept the situation because it hurts his ego, then usually a mother has a more intimate relationship with her child. A mother rather focus on what she 
should do to solve the problem, or to reach some improvements. The situation was the same in my own family. My mother is still looking for alternatives up to the present day in order to reach some further advancements. She never gives up the hope that I can be even better than I was on the previous day. She always says to me: "Every day is a new hope, since you were born and you are my treasure."

In chapter 6 titled Initial impressions of the Petö Institute and Hungary Interviewees shared their first impressions about Hungary. The challenges they had to face up to for instance, travelling from Israel to Budapest cultural and language differences. At that time there were no diplomatic relations and no direct flights so first they went to Vienna then took a train to Hungary. The Institute's staff could not speak English only Hungarian and they found the rules very strict for example carriages were not allowed to use there. They left behind everything, family, jobs, they just took the chance in the hope this could make their children more independent, more mobile. On the contrary, they found so much joy on daily basis while they were observing the progress in their children's mobility, not to mention in their motivation. As Rony Schenker viewed the sharpest contrast was: “... in Israel they were not given the opportunity to tap all their capabilities. Our belief in the child's ability to change was more limited. Also on the level of anticipation. I think that conductive revolution was first of all the perception or the faith that we have in the children's potential for change."(Schenker, 2016.45.p.) I completely agree with her words because first the child must get an extrinsic motivation from conductors or parents, then it slowly transforms into an intrinsic motivation as soon as she starts to believe in herself. In the Institute nobody judges you but rather emphasizes what you can do instead of repeating all the time your weaknesses and missing abilities. This acceptance gave me strength during my school years where I met teachers who could not understand the importance of motivation and positive encouragement. "You can do it!" from my conductor I can still hear the words of cheer and she always could give me huge wings and helped me to survive the rest of the week in school.

The idea of changing was well received among people from Israel but there were regulations they disliked and wanted to modify. One of them was aside from conductors, no other professionals were engaged in the rehabilitation of the child. The other was the approach for not adopting the environment to the child but adopting the child to the environment. Because of this concept the minimal use of assistive devices were allowed. They wanted more flexibility and greater role for parents because at that time most of the Hungarian children lived in a dormitory therefore parents were not taking part in the children's therapy. The third was how they thought about inclusion which was described in chapter 13 titled Inclusion into the regular educational system. This was one of the fundamental principles by Tsad Kadima: inclusion as a process and not as placement.

In the 15 chapter titled Facing forward the reader gets a picture about their vision of the future. I truly liked the question by the conductor Naomi Rotem. "What about young adults with CP, what about the older ones?" This is my question too. We need further treatment because with ageing our conditions decreasing day after day but it seems nobody hears our calling for help. In the future professionals who work in Conductive Education Centres really should come up with some solutions, if they consider Conductive Education as a lifestyle from infancy to adulthood.

I would like to recommend this book for parents and therapists. I hope the book review will arise your interest. 


\section{INTELLIGENT LOVE \\ PARENTS' ACTION FOR CONDUCTIVE EDUCATION ${ }^{12}$}

\section{Authors:}

Adrienn Oravecz

Eszterházy Károly University

E-mail address of the first author:

ora_adri@msn.com

\section{Lectors:}

Tünde Rózsahegyi

University of Wolverhampton

Magdolna Estefánné Varga

Eszterházy Károly University

Veronika Schéder

University of Debrecen

Katalin Mező

University of Debrecen

Oravecz, Adrienn (2017): Intelligent love: parents' action for conductive education. Különleges Bánásmód, III. évf. 2017/1. szám, 109-110. DOI 10.18458/KB.2017.1.109

Bibliography of the subject of this recension:

Graham Jo Mcguigan Chas, Maguire Gillian(Eds). (2010): Intelligent Love. Birmingham (England): Conductive Education Press. ISBN 978-0-9569948-2-0

Keywords: conductive education, parenthood, cerebral palsy

Disciplines: Special Education

The title of the book was selected carefully and it is thought-provoking. Comes from Mária Hari who said the following when Standing up for Joe was broadcasted: "Love is not enough here. It must be an intelligent love." In my opinion and experience intelligent love is a very active and often demanding because it gives you a positive belief in yourself from the parents' side but also gives a security that if you need help the parents are ready to give you the necessary support at any moment. Let me give you an example of intelligent love from my life. Every time I go to Eger for $\mathrm{PhD}$ consultation my mother worries but she hides and keep these to herself. Rather she trusts in me that I will arrive there and back home in safe. This positive trust is the intelligent love.

The book begins with three very expressive citations. One by Christopher Reeve reads as follows: „Once you choose hope, anything's possible” The other citation by Hannibal” We will either find a way or make one" The third one written by Károly Ákos and Magda Akos" It is especially important in the case of a motor-disordered child that the parents are able to develop an idea of their own abilities, which surpass those of all the specialists so

\footnotetext{
12 The editorial board does not take any responsibilty for the English of the papers. Indeed, we made some slight changes but wanted to keep the style of the authors.
} 
far...Parents should not be hindered from understanding their child's situation correctly, neither trough illusions nor through force" The book is a collection of stories by 13 presents. The quotations perfectly symbolize their journey for their disabled child and their individual fight for Conductive Education. The reader gets a global picture through their narration because they come from Brazil, Belgium, Germany, New Zealand, United Kingdom, and United States.

The book also gives you an interesting picture of Hungary in 1980s through the parents 'eyes. One of the positive things they mentioned: "The Hungarians did things very differently. They met the problem face on, the individual children themselves. It seemed to us to be the logical, intelligent bringing together all the specialist skills available (even in the UK) needed best to help children with motor disorders." (Graham, McGuigan and Maguire, 2010, p.59)

I chose Patti Herbs's story to share with you because not only she could help to his son Justin but also too many others with the same diagnose. After she recognised the positive changes in Justin motor development she decided to establish her own Conductive Centre in 1998. Today the centre employs 4 occupational therapists and 4 full-time conductors they are working in a transdisciplinary team where all the professionals are responsible for evaluating the children, planning the programme in a conductive way. The Centre for Independence helped to de-mystify Conductive Education in the United States. This transdisciplinary model made the services available for low-income families in the Chicagoland area. Today, the Centre provides Conductive Education programming for over 125 children a year. Petti was one of the devoted parents who made her way to teach intelligent love to other parents through Conductive Education. Justin learnt sitting independently on a toilet in private. This was a remarkable achievement for having an aide with him for the entire process according his mother's opinion. The level of success differs from each other as well as their syndrome. All the children who are now young adults like me could make a progress towards independence.

I recommend this book for parents who want to learn how to love intelligently. 
